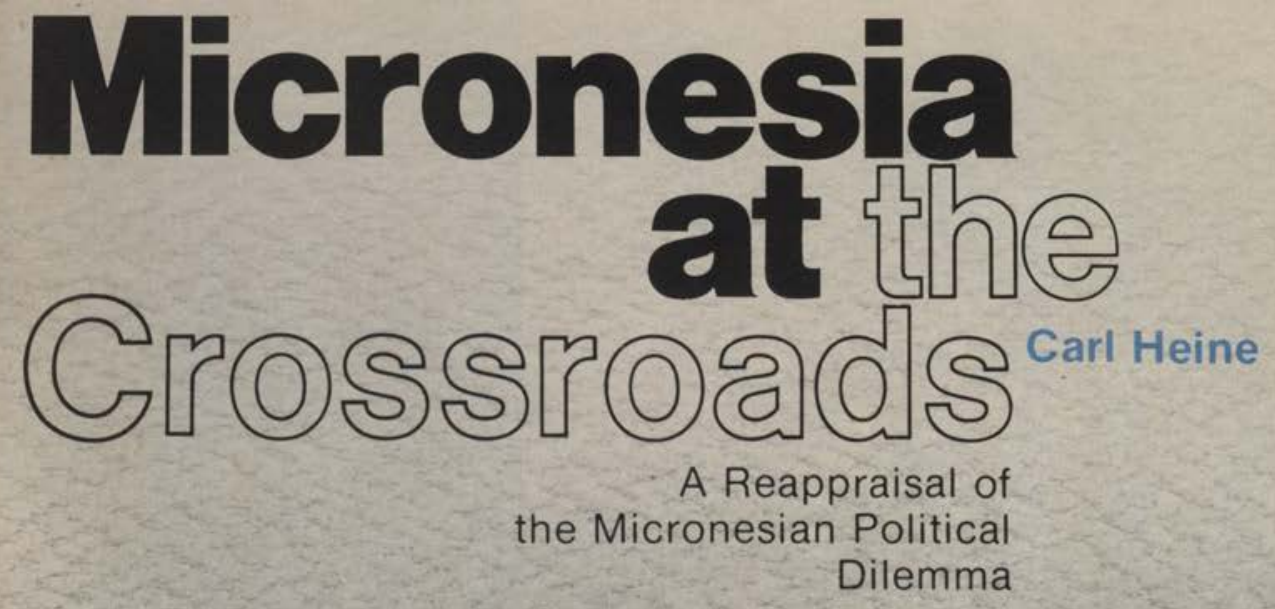




\section{Micronesia at the Crossroads}

Carl Heine

Covering an area of the Pacific Ocean larger than the continental United States, the more than 2,000 islands and atolls of Micronesia-a United $\mathrm{Na-}$ tions strategic trust territory under U.S. trusteeship-are emerging as a political entity. Their history since the Spanish discovery in the seventeenth century is a parade of colonial ruleSpanish, German, Japanese, and now American. Today, the many islands and their diverse peoples are confronting the awesome task of determining their political future. Hampered by differences in culture and language, and by attitudes fostered under years of paternalism, the islanders must begin to develop an identity as Micronesians.

As most commentary on Micronesia has been written by outsiders, this book is most welcome-an evaluation and viewpoint of a Micronesian who has been a student of Micronesian history and a close observer of the territory's political development. In Carl Heine's view, Micronesia is standing at the crossroads between political decolonization and autonomy or further dependence on a "neglectful" trustee, the United States. The question becomes, which road to nationalism should be taken?

Here the author attempts to provide a basis for further discussion of Micronesia's future, and offers alternative solutions: complete independence from the United States; a return to traditional ways of life; the formation of a Free Associated State of Micronesia aligned with the United States. 
This book was published by ANU Press between 1965-1991. This republication is part of the digitisation project being carried out by Scholarly Information Services/Library and ANU Press.

This project aims to make past scholarly works published by The Australian National University available to a global audience under its open-access policy. 


\title{
Micronesia A Reappraisal of at the the Micronesian \\ Crossroads Political Dilemma
}

\author{
Carl Heine
}


Copyright (C) 1974 by The University

Press of Hawaii

All rights reserved

ISBN 0708102999

Manufactured in the United States of America 
In memory of my Father 


\section{Contents}

Preface ix

Acknowledgments xiii

Introduction $\quad \mathbf{x v}$

Part 1. The Colonial Episode

1. The Political Setting 3

2. The Three Treaties 10

3. Americans in Paradise 19

4. Western Impact on Micronesia 24

5. Agents of Change 30

Part 2. The Micronesian Inquisition

6. Micronesia's Response 43

7. Self-determination 48

8. Rendezvous with Destiny 55

9. Who Plans for Micronesia? 62

10. Beyond Trusteeship 68

11. Free Association 79

12. The Only Sure Promise 85 
viii Contents

Part 3. The Micronesian Dilemma

13. Predicament of a People 91

14. Independence for Whom? 96

15. Promise and Fulfillment 104

16. Unification and Self-government

17. The Challenge of Leadership 118

18. Negotiations: Résumé and Review 124

19. Freedom from Within and Without 134

Epilogue: An Overview 144

Postscript 171

Appendix 1. Major Political Events in the Process of Decolonization, since $1967 \quad 177$

Appendix 2. Statement of Intent of Future Political Status Commission

Appendix 3. Jurisdictional Boundaries and Political Leanings of the Six Districts of Micronesia 185

Appendix 4. Text of the Trusteeship Agreement for the Trust Territory of the Pacific Islands 188

Bibliography 193

Index 205 


\section{Preface}

I WANT TO ADMIT that in this book I have committed the cardinal sins of oversimplification, overgeneralization, and propounding value judgments. No one can write about the present political upheavals in Micronesia without inviting charges of vagueness and arousing others to positions of controversy. No one can write about the diverse, complex, and often confused world of emerging Micronesia without feeling inadequate to the task and even guilty about the results of his efforts.

Yet the task of writing such a book was compelling. One Micronesia I knew was the one conveyed to me through the oral tradition. Yet from the time I was taught to read, and especially during the last fifteen years, I came to discover, through a considerable amount of literature written by non-Micronesians, another Micronesia. And I came to realize that the Micronesia of the oral tradition and the Micronesia of the written literature are not the same and that, although the assessment of the "outside observer" was nice to have, most of the time it was not a true reflection of the real Micronesia I thought I knew.

This book, therefore, is about the Micronesia that I, a Micronesian, have come to know. It is not necessarily the Micronesia that official Washington knows, or the Micronesia of the anthropologist, geographer, or missionary. In short, it is the Micronesia of the insider rather than that of the visitor, however much a student of our land he may be.

One must almost have to be a Micronesian to understand the nature of this great dilemma, and to appreciate the intensity of 
feeling it arouses. It is a dilemma posed by the availability of more than one course of action. To simply cast away the yoke of Western colonialism is not enough, for there is disagreement at home between those who desire to preserve the old archaic servitude system and those to whom that desire is just as repugnant as the retention of colonialism. The scope of the Micronesian's internal struggle at the crossroads is, therefore, twofold.

The consolidation of national feeling in Micronesia will prove much more difficult in the years to come. However, the immediate problems of devising a satisfactory posttrusteeship political framework are much more urgent. Micronesian leaders are rapidly being faced with the need to make fundamental choices in both internal and external policies, choices that will affect the future of Micronesia. The structure and philosophy of government they lay down now and the direction they give future development, with regard to both outsiders and Micronesians, will ultimately decide whether the proposed compact of free association with the United States will be a blessing or a bitter disillusionment.

There is conflict between the drive for modernization, which will mean the material enrichment of the lives of the Micronesian people, and the desire to preserve those elements of the Micronesian cultural heritage that are being and would be in ever-increasing quantities threatened by the modernizing process. Micronesia is caught between opposing ideological forces proposed from outside and within.

The second phase of the book deals with why Micronesians wanted to decolonize their islands and with how the question of unity became a serious threat to the future of these islands and with the dilemma facing the decision-makers.

I have presented a subjective view of what the colonial powers have done to Micronesia with particular emphases on what the United States of America is doing in Micronesia, what the Micronesians are doing, and why they are doing what they are now doing. The book is about Micronesians' experience of colonization by outsiders and their attempts to achieve decolonization and the building of a future island nation. Colonization is an experience that has touched all Micronesians.

For those unfamiliar with Micronesia or with her experience as a ward of Uncle Sam, the book may present issues and attitudes difficult to appreciate or accept. It may appear to some that I have grossly distorted the American image in Micronesia or that I have 
distorted the issue of Micronesian unity. I have, with as much care as possible, attempted to be objective where objectivity is required.

My purpose in writing this book is to provide a basis for discussion of Micronesia's future by presenting one point of view of the range of problems facing Micronesia in her struggle to gain a new status, a new way of life, and a new freedom. Certainly, no attempt is made to advance final solutions. There are suggestions and expressions of political idealogy to be considered. Micronesians themselves must ultimately find the real solution.

Throughout this book, I have taken the position that the only realistic political course for Micronesia is to enter into a state of free association with the United States. However, as a Micronesian, I am colonized, and perhaps my feelings may have been colored by my own experiences. I have also lived in the United States. I do not minimize at all the attraction of the richness, the variety, the humor, the liveliness, the sheer vitality that are contained within the American society. I am conscious, too, of the large number of Americans who are appalled by the social ills that are damaging the United States both at home and abroad. These social ills are slowly, but surely, coming to Micronesia too.

The Micronesian colonial experience took a different form six years ago when the Congress of Micronesia came into existence. It is during this six-year period that Micronesians began for the first time to confront the administering authority. 


\section{Acknowledgments}

IN THE PROCESS of writing this book over the past several years, I have been fortunate enough to have had the constructive criticism and encouragement of the following friends and associates who have read parts or all of this book in manuscript form: the late Professor J. W. Davidson of the Institute of Advanced Studies, The Australian National University, who also had served over the years as senior consultant to the committees on political status of the Congress of Micronesia; Professor Emeritus Leonard Mason, formerly of the University of Hawaii; Robert Trumbull, chief of bureau, South Pacific, the New York Times; Dwight Heine, special consultant to the High Commissioner; and James Manke, chief of the division of public information, Trust Territory government.

I am also grateful to the editors of The Journal of Pacific History for giving me their permission to reproduce my article from volume four of that journal, 1969. This article is presented in slightly different form as chapter 8 of this book. Also I want to thank Dr. Marion W. Ward, editor of the Politics of Melanesia, for allowing me to reprint my article, which was published in that book by the University of Papua and New Guinea, and the Research School of Pacific Studies, The Australian National University, 1971. This article formed the basis of chapter 16 of this book.

I particularly want to offer my appreciation to two former Peace Corps attorneys, W. Stephen Miller and Michael A. White, both of whom are now working for the Congress of Micronesia. 
They each have read portions of the manuscript and have extended aid and advice during the writing of this book.

I also want to record my gratitude to Margaret Kanost for her aid in the compilation of the index for this book, and to Iris Falcam, former librarian of the Congress of Micronesia who was always cheerful and ready to offer assistance in locating needed research materials.

I wish to acknowledge my debt to Evelyna Akimoto who not only typed and retyped the manuscript in its entirety, but helped as research assistant. To her I extend my sincere appreciation.

Finally, I want to express my appreciation to the Joint Committee on Future Status of the Congress of Micronesia and especially to its chairman, Senator Lazarus E. Salii, for giving me the rare opportunity to work closely with the Joint Committee in its negotiations. I thus was able to observe some of the problems affecting Micronesia's future status at close range. I am equally grateful to High Commissioner Edward E. Johnston for granting me leave of absence from my job in the Executive Branch so that I could work with the Joint Committee on Future Status.

I owe special gratitude to Janyce K. Blair whose suggestions and editing of the manuscript were most welcome.

I cannot close without thanking my wife, Susan, who provided a perfect home environment in which I was able to complete this study.

Needless to say, I, alone, am responsible for the contents, opinions, and conclusions of this book. 


\section{Introduction}

THE DISTANCE between Washington, D.C., and Micronesia is great. Washington has ignored this area for a long time. Its policy toward Micronesia in the last twenty-odd years has not been consistent. At one time, its policy was to keep Micronesia out of the mainstream of the twentieth-century world, a policy popularly known in Micronesia as the "zoo philosophy." This policy was rejected by the Micronesians. Later on, beginning with the Kennedy administration, an altogether different policy was adopted, one designed to accelerate the educational, social, economic, and political processes. Coincidental with this later approach, attempts were made to bring Micronesia politically closer to the American system. Actions were taken to incorporate Micronesia as a U.S. territory; commonwealth status was also offered. Both were rejected by Micronesians.

When it became apparent to Micronesians that Washington was in fact disregarding the terms of the Trusteeship Agreement and was trying to annex their islands, steps were immediately taken by the Congress of Micronesia to institute the process of decolonization and the future political status negotiations. Free association or independence, should free association prove unacceptable to the United States, were proclaimed the goals of Micronesia by the Congress of Micronesia.

As Micronesia nears the achievement of her goal, however, the forces of disunity within our country are beginning to emerge, causing great difficulty in achieving a united front and the settlement of the status issue. This dilemma is one of the many prob- 
lems creating difficulty not only between the Joint Committee on Future Status and the U.S. delegation, but also between the disstricts and among the members of the Congress. In addition, there is the problem of the conflict between the old and the new, for the traditional past is still very much a part of us, as is modernization and the rising level of expectations it has brought.

In the quest for change, there is also the problem of identity. Can Micronesia find her way to the right form of political status for herself? Only time can tell. Micronesia, too, must change internally; she cannot hope to find her future in this struggle if she is unwilling to exact reforms within herself.

Thus, Micronesia's challenge is not confined to the struggle against the outside forces of colonialism, it is also the need to recognize and accept internal change where change is necessary, necessary not only to Micronesia as a whole, but to the individual districts as well.

Economic, political, and social forces are flowing with a tidal sweep over communities and villages throughout Micronesia that are only half conscious of their occurrence. Wise statesmen are those who foresee what time has brought, and endeavor to shape institutions and to mold men's thoughts and purposes in accordance with the change that is silently overtaking Micronesia.

And, so, burdened by internal dissension, challenged by the task ahead, Micronesia struggles toward freedom and the building of a nation state. 


$$
\begin{array}{ll} 
& \text { The } \\
\text { Part I } & \text { Colonial } \\
& \text { Episode }
\end{array}
$$




$\begin{aligned} & \text { I. } \begin{array}{l}\text { It is only with the revolution of } \\ \text { decolonization that the colo- } \\ \text { nized reenters bistory, begins } \\ \text { to make bistory. }\end{array} \\ & \text { Political } \text {-David C. Gordon } \\ & \text { Setting } \text { Self-Deternination and History } \\ & \text { in the Third World }\end{aligned}$

FOR A LONG TIME, even before the Age of Discovery, the tiny islands and atolls that make up the Trust Territory of the Pacific Islands, scattered over 3 million square miles of salt water in the western Pacific Ocean, have been the home of over one hundred thousand Micronesian people. The discovery and colonization of these islands and atolls by the Spanish, the Germans, the Japanese, and now the Americans, have not changed this historical fact.

In time of war, and in time of peace, this was their home. Though foreign flags were raised, and treaties and trust agreements signed, this was their home. Colonialism shaped Micronesia and made its people more aware of their geographical distance from and their relationship with each other. It helped to decrease the Micronesians' sense of isolation by bringing the islands together under one roof.

Micronesia, the Trust Territory of the Pacific Islands, includes three groups of islands-the Marshalls, the Carolines, and the Marianas. These groups of islands are spread over some 3 million square miles of ocean, an area larger than the United States, but have a combined land area of 700 square miles, an estate smaller than half the state of Rhode Island.

Its eastern perimeter in the Marshalls begins about 4,100 miles from San Francisco and 2,100 miles from Honolulu and extends westerly reaching approximately 6,000 miles from San Francisco and 4,000 miles from Honolulu.

Its westernmost perimeter is Palau in the Western Caroline Islands, which is approximately 400 miles from the easternmost tip of 
the Philippine Islands and about 200 miles from the closest eastern tip of Indonesia.

This island empire encompasses over 2,000 islands varying from mere coral atolls in the Marshall Islands to volcanic islands in the Western Carolines and the Mariana Islands. Its climate is tropical with seasonal changes. The temperature ranges from 70 degrees to 85 degrees Fahrenheit and the humidity is relatively high. Weather conditions are also subject to great local variations and to rapid changes, especially on the high islands.

The natural economic resources of the Trust Territory are meager. Under the present conditions, they are adequate to support the population only at a subsistence level. The possibilities for future expansion are limited not only because of the small land area but also because of the lack of any potential natural resources for further development.

The economic welfare and progress of the peoples of Micronesia are almost entirely dependent upon agricultural and marine resources, imported goods, and large government payrolls.

Agricultural resources are mainly coconut crops, taro, cacao, and a limited variety of tropical fruits and vegetables.

Marine resources have the greatest possibility for the future. Large quantities of commercially valuable fish exist throughout the entire area.

Micronesia was placed under the International Trusteeship system at the San Francisco Conference on April 25, 1945. However, the initial submission of a draft trusteeship agreement for the former Japanese mandate, now under American jurisdiction, was delayed, primarily because of difficulties within the United States, especially between the Department of State, which opposed outright annexation, and the military, supported by the Congress, who feared that American strategic interests in the islands would be impaired if fortification of these islands were made subject to Soviet veto. So strong was the conflict between the State Department and the military leaders in the United States that "a subcommittee of the Senate Naval Affairs Committee, composed of Senators Byrd of Virginia and Eastland of Mississippi, Democrats; and Senators Tobey of New Hampshire and Capehart of Indiana, Republicans, arrived in San Francisco to make sure," interests in the former Japanese-mandated islands. The draft agreement was submitted to the United Nations on February 17, 1947. It was approved by the Security Council on April 2, 1947.

Interestingly enough, twenty-seven years later, as the United 
States and Micronesia confront one another in a new series of negotiations, in an attempt to comply with the letter and spirit of the Trusteeship Agreement, both sides are again having great difficulty in reaching accord. The same group in the United States which has always advocated annexation of these islands is still very much active and alive today-the military.

But, let us return briefly to the Japanese and American eras. The Japanese attempt to integrate the Pacific Mandate (Micronesia) into the Japanese empire was abruptly terminated by the attack on Pearl Harbor on December 7, 1941. With the end of World War II, peace came again to the islands of Micronesia. Except for a few of the outlying islands and atolls that had not been affected by the war, the end of hostilities found Micronesia a shambles and conditions chaotic.

On July 19, 1947, the new Trust Territory was turned over to U.S. Navy administration on an interim basis. Military government was organized on an emergency status. Title to lands had not been decided, nor had the actual role of the United States Navy in the governing of the territory. Much of the time, the military was functioning under the rules of international war. This was a new experience for the United States.

The United States was faced with governing an area taken by assault. In Micronesia, all normal conditions of everyday life had been disrupted, and it was necessary that law and order be restored at once. A starving population waited to be fed and measures to restore economic stability needed to be taken. Health services to prevent the spread of disease also were needed. There were problems of transportation, education, farming, fishing, banking, public utilities, and postal services that had to be resolved.

Admiral Chester W. Nimitz was appointed the first military governor by the president of the United States. Military proclamations were issued under his command. The people of Micronesia became accustomed to a new life-style, a style where everything was handed out free. Massive operations in the area by the U.S. Navy, accomplished with few worries over cost or logistic support, resulted in Micronesians' present fond memories of the military government.

However, in 1951, when the administration of the Trust Territory was turned over to the Department of the Interior, reality quickly relegated the abundant life under the military government to pleasant remembrances. The Department of the Interior did not give out anything free. It had a smaller staff, less money to run the area, fewer ships, and it showed very little experience in island government and 
island affairs. Although the Micronesian's attitude toward interior department administration has improved considerably during the past decade, it does not approach the regard extended to the navy.

Recollections of the Japanese government and its activities in Micronesia did not help much the Micronesian trying to paint a better picture of the current administration run by the Department of the Interior. The Japanese were far superior in the economic activities and programs they initiated in the islands. Living under three different administrations offered Micronesians an opportunity for comparison they could not let pass. The U.S. Navy was good, it defeated an enemy who was cruel in time of war, but the Interior Department, which was obligated to improve and build a shattered economy, was no match to what the Japanese, although oppressive in their administration, had made of the economy of the islands.

Beginning in the early part of the last decade, more and more Micronesians were gradually brought into the mainstream of the government of the Trust Territory. However, there is truth in the saying that "you cannot give power in small doses at regular intervals." 2 The Congress of Micronesia, created in 1965, became the focus of attention throughout Micronesia. A large measure of legislative authority was bestowed on this organization, but soon it proved to be not enough, and the new legislators began clamoring for more power and authority.

Since 1965, rapid changes have been made in the social, economic, and political sectors. No indigenous public institution has caused and made more changes than has this new agent of change-the Congress of Micronesia. The administering authority, up to the time the Congress of Micronesia came into existence, had never been challenged nor opposed. In this new legislative body, however, it had an adversary.

Let us briefly examine the development of local government units in Micronesia. The development of local municipalities, as well as local participation of the indigenous people, was encouraged by the naval administration, but it was not until April 1957 that the administration (now under the Interior Department) actually took steps to begin chartering municipalities throughout the districts in Micronesia. The main objectives in the chartering of municipalities were "to delineate municipal boundaries, define authority, specify taxing and legislative powers, set up procedures for the election of municipal officers, and outline their duties." 3 This program continued in every district 
throughout Micronesia. Today there are more than forty-six chartered municipalities, encompassing even the remote villages of Micronesia.

In reality, the establishment of local municipalities has been more a government sanction of the remnants of the traditional systems than it has been the establishment of the Western system of local government. For example, the magistrates almost always have been the hereditary chiefs and the fact that elections of these officials are staged by the government is a misleading one. But, the traditional system is fading away, and the actual power of the magistrates has gradually faded with it.

The district legislatures of the six regional districts came into existence at different times after World War II. The Palauan Congress (now Palau District Legislature) has the distinction of being the first legislative advisory body to be established under the authority of the United States military government, prior to the approval of the Trusteeship Agreement. The Palau Congress was established on July 4, 1947, and the Trusteeship Agreement was signed on July 18, 1947. The Marshall Islands Congress was proclaimed an advisory body to the civil administrator in November 1949; its final approval by the military high commissioner came in June 1950.

The Yap Islands Congress (now Yap District Legislature) had been in existence unofficially for a number of years prior to the time the Interior Department assumed responsibility in 1951 and it was officially recognized in that year. This congress for many years served the district of Yap without any representation from the outer islands of the Yap archipelago whose people had been, in effect, disenfranchised. In 1968, by an act of the Congress of Micronesia, a new bill for a charter, which included a provision for the representation of the outer islands' people, was introduced and signed into law, thus creating the present legislature, which represents, for the first time, all of Yap District.

In the Eastern Caroline Islands, the Ponape Islands Congress came into existence after the high commissioner approved its charter in 1952. In January 1963, the Mariana Islands District Legislature charter was finally approved and signed into law. Prior to this time, the northern islands of the Marianas were served by the Saipan Municipal Council, which has the distinction of being the first local government unit to have been chartered pursuant to a directive issued by the United States military government on May 28, 1947. On September 25th, in the same year that the Mariana Islands District Legislature was chartered, the high commissioner granted Truk District Congress its charter. 
These "district legislatures," established at various times and stages of development, came into existence not as bona fide law-making bodies, but as advisory bodies to their respective district administrators. They were the first training ground for most of the leaders of Micronesia today. They gave a somewhat illusory sense of belonging to and participation in the government of the districts in which they existed, but these six original legislative bodies were successful in that they broadened the horizons of local leaders in the development of political institutions in Micronesia. ${ }^{4}$

In this decade, the Micronesian people and their leaders are hopeful that a political settlement regarding their future status may be reached. Although the islands of Micronesia are small and scattered, weak and powerless and less endowed than others in wealth and natural resources, they are serious and determined in their pursuit of a better world for themselves - a pursuit that hopefully will result in a Micronesia for Micronesians, and a Micronesia by Micronesians.

To Micronesians, if it is right that governments should be responsible to the governed, then it is wrong for one people to be ruled by the government of another. In this context, alien rule and democracy are clearly incomparible. Thus, if democracy is considered a condition of individual freedom, then alien rule is also incompatible with freedom. To Micronesians, alien rule is humiliating. And because Micronesians in general share this attitude toward a life under their islands' present political status, it has become necessary that the present trusteeship status be renegotiated. In 1969, the Congress of Micronesia, the highest legislative body in Micronesia, started to put into motion the process for the decolonization of Micronesia. Negotiations have been held in Washington, D.C. (1969), Saipan (1970), Hana, Maui, Hawaii (1971), Palau (April 1972), Washington, D.C. (July 1972), and at Barbers Point, Hawaii (September 1972). All six rounds of discussions were attempts at resolving the political situation of these islands.

The coming together of the people of Micronesia has not been easy. The incentive for their alliance has been an introduced one-the effect of outside forces upon their lives-rather than an internal one based on a desire for unity. Indeed, there is a degree of superficiality to the quest for a new political status in view of the fact that the diverse cultural entities throughout Micronesia have as yet to prove to themselves that they can live in harmony. Historically, these are a people who lived in complete isolation until they were discovered in the sixteenth century and who, since then, have been continuously colonized by outsiders. 
This is the state of affairs in Micronesia circa 1973. There are headaches and enormous problems ahead awaiting to greet the new state of Micronesia whether statehood be in the form of free association with the United States or complete independence. Let us return in history and see what has happened during the past four hundred some years, the period between the "Treaty of Tordesillas" (1495) and the present Trusteeship Agreement (1947).

NoTES

1. James N. Murry, Jr., The United Nations Trusteeship System (Urbana: University of Illinois Press, 1957), p. 36.

2. John Plamenatz, On Alien Rule and Self-Government (London: Longmans, Green and Co., 1960), p. 119.

3. Norman Meller, The Congress of Micromesia (Honolulu: University of Hawaii Press, 1969), p. 271.

4. Carl Heine, "Micronesia: Unification and the Coming of Self-Government," in Politics of Melanesia, ed. Marion Ward (Canberra: Research School of Pacific Studies, Australian National University, and University of Papua and New Guines, 1970), pp. 197-198. 


$\begin{aligned} \text { 2. } & \begin{array}{l}\text { Through global conquest the } \\ \text { dominant Western powers } \\ \text { worked to reshape tbe world in } \\ \text { their own image and tbus roused } \\ \text { against themselves the forces of }\end{array} \\ \text { The } & \begin{array}{l}\text { nationalism wbich are both the } \\ \text { bitterest enemies of imperialism }\end{array} \\ \text { Three } & \text { and, perversely, its finest fruit. } \\ \text { Treaties } & \text { Rrom Empire to Nation }\end{aligned}$

SINCE the mid-seventeenth century Micronesian social patterns have been subjected to violent change by the imposition of external social, economic, and political forces. The social transformation in Micronesia especially has been augmented and aggravated by the domination of four successive foreign rulers: Spain, Germany, Japan, and the United States.

The basic principles of government and the social policies of these powers, at the time of their controlling the islands, differed considerably. Spain ruled under the influence of medieval Catholicism. Germany was guided largely by economic imperialism. Japan's objectives were military and economic exploitation. The United States' administration amounts to apathetic paternalism with strategic military considerations.

Whole social and political patterns of life have been modified, changed, or destroyed. The problem in the Trust Territory has been more acure and serious than in other colonized areas. A seafaring people was abruptly subjected to the abuses and the introduced social parterns of more advanced cultures and societies. Thus, in Micronesia, historical forces have played a major role in shaping the present institutional patterns of the indigenous populations.

\section{Treaty of Tordesillas}

The earliest act of colonization affecting Micronesia occurred around 1494 A.D.; it was linked with the early spread of Christianity and the Age of Discovery. Although these events were determined largely by historical circumstances and movements occurring in Europe during the period of the Renaissance, Micronesia, nevertheless, was affected.

The discoveries made by the early European navigators and the 
beginning of the Renaissance in Europe played a significant role in these seemingly remote and isolated islands. The Renaissance stirred men's minds and moved them to learn more about strange and faraway lands. It captured the imaginations of such men as Christopher Columbus, Vasco da Gama, and Ferdinand Magellan, who, in turn, discovered new lands in the New World and beyond.

After the discovery of the West Indies by Columbus, Pope Alexander VI, in 1493, divided all newly discovered lands between Spain and Portugal. Lands to the west of the meridian 100 leagues west of the Cape Verde Islands would go to Spain. This line continued around the world, giving India, Africa, and Malaysia to Portugal, and all of the New World except Brazil to Spain. According to this dividing line, Micronesia fell under the Spanish sphere of influence.

In the year 1494, in the small town of Tordesillas in northcentral Spain, Spain and Portugal signed the Treaty of Tordesillas. The treaty divided the non-Christian world into two zones of influence. In principle, the treaty followed the Papal Bull issued earlier in 1493 by Pope Alexander VI, which fixed the demarcation line of newly discovered colonies belonging to the two countries. Thus the Treaty of Tordesillas became the first formal act of political development that indirectly, but decisively, influenced the course of events in the islands of Micronesia.

The Age of Discovery in the sixteenth century brought the first white man to the shores of Micronesia. It is King Charles I of Spain who precipitated the events that brought knowledge of this island empire to the rest of the world during that era. To satisfy his desire for wealth, gold, and silver, Charles I employed Ferdinand Magellan as captain general of His Majesty's Armada and instructed him to sail to the Pacific Ocean. Magellan set sail on March 6, 1521; this event marked the beginning of a conquest of Micronesia by Spain and successive powers that was to run throughour modern history, to be halted only at the end of World War II.

Following the signing of the Treaty of Tordesillas, Spain quickly gained control of a greater part of the Pacific area, including the islands which centuries later were to become associated with the United States as the Trust Territory of the Pacific Islands.

In 1668 , Spain took the first steps to subdue the islands and bring them under direct Spanish domination.

\section{Spain}

As early as 1509 , the Portuguese had established key bases in the Malaysian area. Magellan's voyage broke up Portugal's temporary 
hegemony over the Pacific area, including the islands which centuries later were to become part of the Trust Territory. ${ }^{1}$

The introduction of Spanish ideas and methods in the Mariana Islands was resisted by conservative elements among the native Chamorro population and the conflicts developed into open warfare. After nearly thirty years of brutal warfare, the natives were subdued and the sovereignty of Spain extended completely over the Marianas. The Chamorro, a once proud people numbering approximately 70,000 to 100,000 , were reduced to a population of 6,000 or 9,000 . Catholicism became the dominant religion at the point of the sword.

In general, Spanish colonial policy in the Marianas was directed toward the Christianization and pacification of the natives. Agana, in Guam, was made a port of call for vessels plying across the Pacific. In later years, the policy shifted to the maintenance of Spanish sovereignty in the islands as a bulwark against the imperialistic ambitions of other European powers, particularly those of Germany and Great Britain. At any rate, Spain made no attempt to exploit or develop the islands economically.

Although the Marshall and Caroline islands were regarded as lying within the Spanish sphere of influence, Spain made little attempt to extend effective control over them until the latter part of the nineteenth century. Two earlier attempts had been made by the Spanish to establish missions in the Western Carolines, Sonsoral in 1710, and Ulithi in 1731. In each case the missionaries were slain by the natives. This discouraged the Spanish from further intervention in the Carolines until the 1870 s.

The Spanish made no attempt at that time to establish administrative operations or colonies in the Marshall Islands. Nor until other European powers, particularly Germany, sought to gain control of these islands did Spain take steps to assert her historical claims.

Although Spanish influence in the Marianas was strong, it did not spread much to the rest of Micronesia. Early Spanish settlers in the Marianas were disappointed that they could not find gold and silver in the new Spanish colony. Their regime, therefore, did not stay long nor make any definite plans to colonize the islands. However, the Spanish had made their influence felt throughout these waters. The Pacific Ocean had come to be known as the "Spanish Lake." 2

Spain's involvement in the Pacific lasted almost four hundred years, but outside of the Philippines and Guam little remains to suggest that the Spaniards were ever here. The history of Spain in Micronesia, excluding Guam, is largely the story of a few galleons, a handful of 
military governors, and a small number of priests. When the nineteenth century closed, Spain was gone, her memorial, vestiges of her language and culture in the Philippines and Guam. ${ }^{3}$

\section{Germany}

The growth of whaling and copra industries in the second and third quarters of the nineteenth century put the islands into commercial prominence. This, together with imperialistic considerations, made the Marshalls and the Carolines objects of rivalries among the Western powers.

Germany, in a rapid expansion of her trading activities throughout the South Seas, purchased Spain's Pacific holdings for $\$ 4.5$ million. ${ }^{4}$ The addition of the northern Marianas and Carolines to the Marshall Islands gave Germany complete control over the area forming the present Trust Territory, and the German empire was now free to exploit her Pacific acquisitions.

The administration of the Marshall Islands during most of the German period was distinct in its form and channels of authority as compared to the later-acquired Marianas and Carolines. In 1888 the German government sponsored the Jaluit Company, a trading company, in the Marshalls and integrated administrative functions with the company's commercial activities.

The governmental staff was small in the early days of the German administration and, in many spheres of activity, assumed a role secondary to that of the Jaluit Company. The imperial administrator was the company's chief executive official. He had the authority to issue all orders and ordinances necessary for general administration, and could levy customs and taxes.

With such a small administrative staff it was inevitable that the German administration followed the principle of indirect rule, under which the primary duty of the administration became the mediation of disputes among the chiefs. All economic activity was handled by the Jaluit Company.

In summarizing, we can state that the German administration succeeded in imposing its control throughout the islands of Micronesia without unduly antagonizing the natives. The Germans improved the territory considerably. They built roads, improved health and sanitation, and explored the islands scientifically for economic potentials. To a certain degree, they protected the natives from unscrupulous traders, and in general they attempted to ease the movement of the natives into the Western world. 
However, the German occupation of Micronesia was brief; it ended with the beginning of World War I. Throughout the years of German domination, the Japanese traders were also busy in the Pacific. The First World War marked the beginning of a new era for Japan in Micronesia. In 1914, Japan entered Micronesia with her European allies, and in 1919, at the Peace Conference in Paris, she was awarded the former German colonies in the Pacific north of the equator. She ruled these islands under a class " $\mathrm{C}$ " mandate of the League of Nations.

\section{Treaty of Versailles}

Japan

For many years Japan had cast an eager eye upon Germany's Pacific possessions. Prior to World War 1 , Japanese businessmen had established a trading foothold in the islands to the fullest extent allowed by German policies.

World War I provided the long-sought-for opportunity. After declaring war against Germany in October 1914, Japan methodically occupied the islands of Jaluit on October 3, Yap and Ponape on October 7, Truk on October 12, Saipan on October 14, and Angaur on October 31. Neither the Germans nor the natives offered any resistance inasmuch as there were no military forces with which to defend the islands." German officials were invited to serve temporarily in the Japanese civil service. Most of them declined and were returned to Germany.

The history of the Japanese administration is long and complicated. Japan's colonial policy can be summarized in terms of four principal objectives: (1) to develop the islands economically to the fullest extent; (2) to use the islands as a means of relieving population pressures in Japan; (3) to spread Japanese culture throughout the islands through education and related methods; and (4) to establish offensive military, naval, and air bases in preparation for war. ${ }^{6}$

The greatest impact upon the natives was made by the influx of large numbers of Japanese settlers, particularly in the Marianas, Ponape, and Palau. In 1935, Japanese outnumbered the natives, and in 1938 they constituted 58.1 percent of the total population. This readily indicates what the social effect must have been upon native customs and institutions.?

\section{Trusteeship Agreement}

With the defeat of Japan in World War II, the disposition of these 
islands was again in question. In 1947, the United States and the Security Council of the United Nations signed a trusteeship agreement. This agreement virtually gives sole power and authority for the administration of Micronesia to the United States.

\section{United States of America}

One of the ironies of American history is that between 1850 and 1920 the United States had several opportunities to acquire all three of the island groups-the Marshalls, Carolines, and Marianas.

The foundation of American interest in the Pacific was laid when the first American merchant ship, the Empress of China, sailed to Canton in 1784. This voyage paved the way for the subsequent flourishing China trade. ${ }^{8}$ The penetration by Americans of the Micronesian islands, however, was for a different purpose.

The first occasion when the United States might have found reason to occupy the Marianas and the Carolines without protest from Spain was during the settlement of the Spanish-American War. For numerous reasons, the United States annexed only Guam at that time. The primary concern of the Spanish-American conference at Paris in 1889 was not wherher the Carolines and the Marianas should be annexed, but what the disposition of the Philippines would be. ${ }^{9}$ Apathy and ignorance on the part of her political leaders and the general electorate among other reasons prevented the United States from acquiring the islands. ${ }^{10}$ The tenaciousness of this atritude was further revealed after World War II when the question of trusteeship came up during the San Francisco Conference in 1945.

Another time the United States had an opportunity to acquire part or all of the islands with a minimum of political disturbance was following World War I. The Japanese had wanted the islands since the turn of the twentieth century. "The outbreak of World War I afforded Japan the opportunity to declare war against Germany and then quickly occupy the islands.

Because she was not at war, the United States could not intervene in the series of negotiations between the three allies. By the time the United States entered the war in April 1917, the destiny of the Pacific islands was already sealed. ${ }^{12}$

It took another world war, the Second World War, to bring the United States into a position where she could bargain from strength. U.S. military forces defeated the Japanese army and navy in the former Japanese Mandated Islands, and this gave the United States control of Micronesia, which she has retained since 1945. 
In essence, the mandate system of the League of Nations was an attempt to put more liberalizing principles into practice. However, in the early nineteenth century, most backward and underprivileged peoples became subjects of international struggles. It was accepted that all colonies existed for the benefit of the mother country. Because of these inhumane attitudes, the founders of the League of Nations felt that a principle of international accountability, with respect to the welfare of non-self-governing peoples, should be instituted. This concept was incorporated under the League of Nations' Covenant. The covenant declared that the welfare of peoples "not yet able to stand by themselves under the strenuous conditions of the modern world" constitute "a sacred trust of civilization." !3

Beginning in the sixteenth century, the Micronesian islands, through a succession of international stewardships, were: a province of Spain by virtue of discovery; a colony of Germany by virtue of colonialistic and economic interest; the mandated South Sea islands under the Japanese empire by virtue of a mandate agreement awarded by the League of Nations; and, finally, a trust territory under United States control by virtue of military conquest and a trusteeship agreement with the United Nations Security Council.

Under all these European and Asiatic powers, the Micronesian people were never given an opportunity to make any political choices one way or another. It was simply the case of a stronger outside force moving in and dominating a weaker and helpless people.

Micronesia has long been a ward of trustees. The history of Micronesia in the last five centuries concerns itself with the affairs of different nations and their colonial activities throughout the islands of Micronesia. It is an account of a people being crushed by preordained events, of a people who seemed destined to float with the tide of colonialism. The total life-style of these islands has been affected by the forces of history, which have played a determinative role in molding the people and their lives. The result is perhaps a classic example of colonialization at its worst. It is only in recent times that the people of Micronesia have gained a greater appreciation of the world outside. In the prior period, the Micronesian world seemed to be centered within its perimeter of 3 million square miles of ocean area.

Civilization made its imprint in Micronesia for the first time through the Spanish, but it did not stop with them. The Spanish laid the foundation for the eventual success of organized religion; the Germans taught the natives trade, business, and the German language; the Japanese brought the Japanese language, boat-building technology, and 
their culture. They also taught the Micronesians advanced techniques of deep-ocean fishing, as opposed to reef fishing. They developed an economy mainly intended to be supportive of the mother country's, but it was so strong that it was able to absorb the Micronesian people into it to such an extent that the people did not feel any sense of loss and alienation within their homeland.

Today, four hundred plus years since Pope Alexander VI divided the newly discovered world into spheres of influence in 1493, the islands of Micronesia, now under the United Stares, are, for the first time in a long and dominated history, again charting a new course of their own through their own elected leaders. For posterity's sake, it is urgent that a new freedom be acquired for these islands, whose destiny has been in the hands of European and Asiatic colonial powers for so long. Whatever the future holds in store for these islands and their peoples, it is hoped that their destiny never again will be decided by outsiders and that the proud peoples of these islands will be able to live with honor, dignity, and self-respect.

NOTES

1. The history of European exploration of the Pacific is too extensive to be summarized in this work. For an authoritative account, see Andrew Sharp, The Discovery of the Pacific Islands (London: Oxford University Press, 1960).

2. Elizabeth K. Antrila, "A History of the People of the Trust Territory of the Pacific Islands and their Education," unpublished Ph.D. thesis, University of Texas, 1965 , p. 81 .

3. Ibid.

4. United States Navy, Handbook, 1948, p. 74.

5. Earl S. Pomeroy, Pacific Outpost: American Strategy in Guam and Micronesia (Berkeley and Los Angeles: University of California Press, 1951), pp. 44-47.

6. Tadao Yanaihara, Pacific Islands under Japanese Mandate (New York: Oxford University Press, 1940), p. 68.

7. Willard Price, Japan's Islands of Mystery (New York: The John Day Co., 1944), pp. 262-265.

8. Werner Levi, "American Attitudes toward the Pacific Islands, 1914-19," Pacific Historical Review, 27 (February 1948), p. 55.

9. Pomeroy, Pacific Outpost, p. 8.

10. Garth N. Jones, Administration of the Trust Territory of the Pacific Islands (Ph.D. diss., University of Utah, 1954), p. 90.

11. Congressional Record Appendix, 80th Congress, and the New York 
Times, January 16,1947, p. 22. (War Department is now part of the Defense Department.)

12. Pomeroy, Pacific Outpost, pp. 19-21.

13. Covenant of the League of Nations, Article 22. 


\section{Botb bosts and guests know \\ 3. they must part, and yet the \\ Americans \\ in \\ Paradise \\ parting is painful, because they do not know bow to do what they know they must do. \\ -John Plamenatz \\ On Alien Rule and \\ Self-Government}

TO MOST PEOPLE outside of Micronesia, the word bikini brings to mind two-piece bathing suits. But to the inhabitants of the islands of Bikini, bikini now means atomic bombs, an island contaminated by radioactivity, and a population compelled to leave its ancient home. ${ }^{1}$

Bikini is a tiny atoll in the central Pacific Ocean-twenty-five separate islets adding up to around 1,200 acres of land. There is not much on Bikini today-most of the organic matter was seared and blackened by the nuclear tests conducted on the atoll in the late nineteen forties and fifties. But Bikini, such as it is, is part of the Trust Territory of the Pacific Islands, one of the last two areas in the world still included under the United Nations trusteeship system.

There are a number of names attributed to this area of the Pacific with its myriad islands. Washington, in its diplomatic jargon, calls it the Trust Territory of the Pacific Islands, and the United Nations with its international mind insists that it is a United Nations trusteeship. The anthropologists say it is Micronesia, meaning tiny islands. A contemporary writer has styled it "Paradise in Trust," and another one called it "Paradise Lost," while still another called it "Our Bungled Trust." To ordinary people, it is simply the "South Sea Islands," land of the noble savage, naked girls, happy and carefree people, a distorted picture of these islands and their people painted by Hollywood and fiction writers. But whatever the name given these islands or the viewpoints the names represent, the reality is that the modern world has indeed engulfed this island empire, and a new twentieth-century society is now in the making.

Micronesia has been under United States administration since the 
end of World War II. The advance of Western civilization reached Micronesia in the sixteenth century, at approximately the same time that it approached the United States.

In recent times, Micronesians have been fairly contented and economically happy, especially during the early Japanese era. However, as World War II approached, the Japanese became more dictatorial. They put people to hard labor and took control of their lands and agricultural products. They even executed some people whose loyalty was not completely in accord with that of the Japanese regime. Thus, once again, the people, whose discovery by the Western nations dated back to the sixteenth century, were placed in a state of stagnation. Under this condition, no real political, economic, educational, and social progress could be made.

World War II was a "war of liberation" as far as the Micronesian people were concerned. Most people were happy to be freed from the hardships they had endured under the Japanese regime during the war years. By far, the present administration has a greater respect for Micronesians. The people have come to like and respect the Americans, not necessarily for any accomplishments the Americans may have achieved, but, rather, for what they expect might happen under a great democracy.

Because of the unfortunate experiences Micronesians have had under previous colonial rulers, the adjustments to a new way of life have been difficult. Under the Micronesian's traditional system, life was carefree, under the Japanese regime it was greatly regimented. Now under the Americans it is another thing.

The American concept of freedom involves responsibility. Freedom cannot exist without order. Thus, for a people whose traditional lives had been easy and carefree and whose experience under previous colonial administrations had been one of submission to domination, democracy presents a new kind of experience.

Micronesians are happy and grateful that they can claim association with the world's richest and most powerful nation, but some of the headaches and problems of the modern world have also become theirs-the difficulties of a money economy, the crying need for education, the complicated concern about the political future of the territory. True, the twilight of Western colonialization has virtually come to an end in this century. But to a certain degree Micronesia is still under colonialization's canopy, and will be for a good many years to come.

Micronesia until 1960 was virtually closed to outside news media. 
The territory had been a sort of a government "museum" in which only authorized persons were allowed to make visitations and tours. Those allowed to visit were usually anthropologists or nuclear scientists. The anthropologists came to study the customs and culture, the scientists to conduct research and atomic tests. As a result, little was known of Micronesia in the outside world.

What of the social and educational development? During the last twenty-odd years during which Micronesia has been under American administration, the U.S. government has spent millions of dollars in the territory. In that same period, under the government scholarship program, Micronesia produced over two hundred college graduates, a few mechanics and technicians, one American-educated medical doctor, several lawyers, and a few agriculturists. To a nation which has been spending billions of dollars to preserve democracy in Southeast Asia and in other parts of the world-and to a nation which has herself revolted against colonialism-these conditions, these needs, as they now exist in Micronesia, must speak our, for what has been accomplished in manpower development has not been enough.

Micronesia was formed and organized into a trusteeship under President Truman's administration. Little interest in these islands was shown during the Eisenhower era. Most recently, under the Kennedy and Johnson administrations, things have begun to move, and Micronesians have felt the impact of the renewed interest. However, much remains to be done-in health, education, agriculture, and manpower training. Under President Nixon's administration Micronesia is entering a new and decisive phase in her political and economic development.

Today, progress is being made in many areas, but at too slow a pace. Until recently there were no clear basic policies to guide Micronesia arising from within Micronesia. What are the territory's primary objectives? What is the government of Micronesia doing with respect to what the people really want? These and many more questions have not been given definitive answers. The Congress of Micronesia, the administration-all Micronesians-must find the answers.

At the same time, it must be realized that in pursuing a new course Micronesia faces many problems-a lack of substantial natural resources, linguistic and cultural differences, lack of trained personnel, indifferences to responsibilities, and lack of social and political awarenesses. Unless these basic problems are resolved, there is little that can be done to attain self-government, self-respect, and a healthy and growing society. These problems all stand in the way of achieving social and political stability. 
The future seems to offer two things for Micronesians: a challenge and an opportunity. The challenge calls for bold and creative leadership. Should we move toward the modern world which is gradually engulfing us? Should we return to traditional ways? Should we maintain the status quo? Or should we seek out a synthesis, based on the belief that there are wisdoms from the past which should be retained and reconciled with what is acceptable from the present? Micronesia has the opportunity to take part in an endeavor that is fraught with problems but that promises great rewards. No Micronesian dare deny the grasping of this opportunity.

Educated Micronesians are questioning the concept of a closer association with the Western world. Many of the older people are not interested in developing a relationship with the outside world. But today's leaders must set the goals for twentieth-century Micronesia.

Many perplexing problems have arisen from the introduction of Western institutions. The influence of these upon the youth of Micronesia cannot be underestimated. These institutions--education, a money economy, travel-have changed Micronesian atritudes and have been influential in the development of a new life-style. But Micronesians cannot continue to live under false assumptions; they cannot assume that everything is going to be okay, that the United States will continue to make money available. Micronesians must accept some of the responsibility for their welfare; they cannot assume that everything is going to turn out right automatically.

Life under various administrations has given most Micronesians a better perspective from which to judge what is good and what is bad for them. It has also taught them to be cautious and to have restraint. Under Spanish, German, and Japanese rules, Micronesia made little progress. Under the present administration, a new atmosphere has been created, which has tended to enhance the wealth of a few and has provided educational opportunities for the youth, but for the older folks, today is still yesterday.

The present generation of Micronesians will decide the ultimate political destiny of the territory - whether that destiny be a federation of many islands, a self-governing territory, an outright territory of the United States, or an independent nation. Micronesians must face the problems, must strive to loosen the archaic order, and must become involved in the modern world. They cannot afford to remain silent and indifferent to the outside world.

For those who have accepted modernization, their emancipation from the traditional order has already been accomplished. There is 
already a degree of rising expectation for better things, a better life. The problems are here. Micronesia must embrace the present with all its blessings and problems, aspire to the future with all its promise and hopes, and build a new society of Micronesia.

NOTE

1. Bikini atoll was returned in 1969 to the Bikinians. The Trust Territory government is in the process of rebuilding the islands so its original owners may once again settle there. 


$\begin{array}{rr}\text { 4. } & \begin{array}{l}\text { Notbing buman can be alien to } \\ \text { us. The new world must be } \\ \text { aired to discover the truth in } \\ \text { every type of buman experience } \\ \text { and must prepare to profit by }\end{array} \\ \text { Impact } & \begin{array}{l}\text { what it finds. } \\ \text { on }\end{array} \\ \text { Micronesia } & \begin{array}{l}\text { Conficts of Power } \\ \text { in Modern Culture }\end{array}\end{array}$

\section{Christianity}

Of all the Western influences that have affected Micronesia, the introduction of Christianity in the seventeenth century had the greatest impact on traditional life. This religious revolution, which began with early Spanish Catholic missions and later included German and American Protestantism and Catholicism, has greatly altered Micronesian society.

After World War II, many missionaries of both the Protestant and Catholic faiths, most of them from the United States, settled in Micronesia. They soon spread throughout the six districts of the territory. Today, in Micronesia, there are church-affiliated educational institutions, such as Xavier High School in the Truk District, a Catholic high school. There is Ponape Agriculture and Trade School (PATS) run by the Catholic church. In Palau, there is Bethania School for girls run by a Protestant sect, the Liebenzell from Germany, and on the island of Saipan, there is Mount Carmel High School run by an order of the Catholic church. Throughout Micronesia, there are smaller privare elementary schools run by both Protestant and Catholic churches.

Most of these schools were established after the Second World War. Neither the Protestant nor the Catholic churches had difficulty in reestablishing themselves in Micronesia after the war. The work of earlier missionaries from both groups had implanted the seed of Christianity and the basis for continuity existed throughout Micronesia.

The establishment of government-financed public schools after the Second World War also went smoothly. The people of Micronesia 
were already literate, they could read and write. It was only the matter of learning a new language.

To a great extent, Christianity can be looked at as a unifying force. It pacified and helped liberate the general consciousness of the people of Micronesia through the teaching of Christian tenets and the activities of its schools and missionaries. Among the important figures and leaders of Micronesia today are many who are a direct product of the Christian establishment in Micronesia.

Micronesia, a very tradition-oriented society, did gain a new consciousness as a result of Christian influence. In the past, loyalty had always been directed toward the hereditary rulers. Christianity imposed a new loyalty and people came to recognize their individuality; through this process Micronesians were able to separate themselves from their traditional orientation and develop a new feeling of self-respect.

In Japan, where Christianity was also introduced in the sixteenth century, just about the same time as in Micronesia, a similar situation developed. As one distinguished Japanese historian pointed out, "A distinguishing feature of the Meiji youth was a consciousness of themselves as individuals, which appears to owe much to the influence of Christianity." I

Christianity was the first of the unifying forces to affect Micronesia. Its overriding influence was to make Micronesians conscious of their new sense of identity and loyalty. Other social forces came much later in the growth and development of Micronesia as a polity.

\section{Government and Geography}

The structure and organization of the various colonial powers, from Spain to the United States, introduced yet another experience to Micronesians. It was the kind of experience that made Micronesia aware, for the first time, of geographical relationships, not only the relationship of Micronesia to the rest of the world, but also the relationship each to the other of the islands themselves.

The Spanish established their headquarters for eastern Micronesia in Ponape, and one in Yap for the western part of Micronesia. The Germans established district governments in all the six districts of Micronesia. However, German headquarters was situated in Rabaul, in New Guinea, which was also part of the German colony at the time. The Japanese followed this same partern in almost every respect, with the exception that their headquarters was situated in Koror, Palau District. Most recently, the Americans have followed the same pattern, but the provisional capital is now at Saipan, Mariana Islands. 
This pattern of government organization imposed by the colonial powers had a great impact on Micronesia. Although it is readily recognized that the people of Micronesia have had great difficulty in unifying their cultural differences, it cannor be disputed that the organization made Micronesia a much more recognizable political entity, or that conceiving of this vast area as a whole brought otherwise unachievable improvements to the island groups. Improvements in communication and transportation, for example, helped make Micronesia a smaller world.

The Japanese established a school for trades in Palau, a school that brought students from all over Micronesia. To a certain extent, the Germans followed this practice. Under the Americans, more schools and training institutions drawing students from all districts of Micronesia have been set up. The impact of this process has been to make Micronesia a much smaller world, a world that has come to be accepted as the home of a people called Micronesians. The Micronesians of today accept this fact.

The concept of governing this great area as a whole comprised of districts has, more than anything else, helped bring Micronesia forth from its traditional background and made it into a new political and physical entity. This much can be attributed to the instruments of government, whose physical presence gave rise to a new physical and geographical unification never before possible.

\section{Liberalism and Feudalism}

Christianity is an aspect of Western civilization. In Micronesia, as has been noted earlier, Christianity brought about a new consciousness and a new loyalty. The Christian God became a new focus of attention and for those converted to the Christian faith (an estimated 90 per cent of all Micronesians), the focus of a new loyalty. It did not altogether replace old traditional loyalty, it was an additional loyalty, one that had inherent liberating elements and was able to provide a new attraction.

With Christianity came literacy, and Micronesian Christians did not stop with the reading and learning of the Bible. Most recently, under the American system of public education, Micronesians began to read other books-Plato's Republic, the writings of John Locke, John Stuart Mill, Lincoln, and Jefferson, and other great literature of the world.

The education process accelerated when the American administration instituted a program that offered scholarships and fellowships to qualified Micronesians for college-level education abroad. This new 
opportunity brought on a new emancipation of the mind. Nothing in the traditional life of Micronesia was left unquestioned by those returning from school abroad.

Christianity had helped open education's door, but it was left to the American regime to provide the opportunities for Micronesians to expand its limits. Education became a new status symbol for many Micronesians. It became the goal of almost every young Micronesian growing up in postwar Micronesia.

With Micronesians returning home fresh from the teachings of Western secular education, there were bound to be social reforms within the established structure of Micronesian society. Liberalism, a new force as opposed to the conservatism of traditional ways, was to become an element that could not be ignored in both private and public sectors of Micronesia.

What forces brought about liberalism in Micronesia? It is difficult to pinpoint. However, one aspect of it is clear. The presence of Americans in Micronesia since 1945 has helped. In fact, American presence provided the soil in which Micronesian liberalism placed its root. The generation of Micronesians who are today's leaders both in the administration and in the Congress of Micronesia were the agents of change who helped spread the idea of liberalism. This group of Micronesians, born late in the Japanese era, went to school right after World War II. They tasted of a new life-style unequalled by their previous experiences under the Japanese or the traditional culture and this taste gave them a hunger for change, an overpowering desire to innovate and to create a new society in Micronesia.

The confrontation between new ways and old, between liberal ideas and feudalistic ideas, is ongoing in Micronesia. There is a feeling of vigor, of rising expectation, sweeping the entire scene that is affecting social attitudes, social values, the political attitudes of the people and the traditional culture. The sacred values and cultural taboos have been examined and are being reexamined.

Despite the yearning for and appeal to Micronesia's past glory by student radicals, and a few unenlightened leaders, Micronesia will never be the same. The twentieth-century world is too much for a weak and outmoded sixteenth-century provincialism to withstand.

\section{Subsistence ECONOMY}

Micronesia's long-stifled economy has been the most affected by the events of recent times. It is basically a subsistence economy, particularly so in the remote areas of Micronesia. This practice has been 
continued, not by choice, but by the inability of Micronesian merchants and, to an extent, the inability of the government to provide the means by which the wants and demands of the people of Micronesia can be satisfied.

Living and dealing in a money economy is not a new idea to Micronesia. Earning money and buying goods and services with it was introduced by the Germans and the Japanese, and the Americans continued it. The Spanish mainly utilized the idea of gift exchange, and stopped at that. This was also the medium of bargain in pre-European Micronesia.

Nor did a money economy have any real difficulty in being accepted by the people of Micronesia. It is a much superior and easier system of satisfying the wants and desires of human beings. It found Micronesia a ready customer. The fact that there are people whose lives revolve around their taro patch and coconut grove is irrelevant to the point, which is that Micronesia as a whole cannot long survive without the assistance of a new economy, based on a new medium of exchange.

The few who are living on a pure subsistence economy are doing so by necessity rather than by choice. The great population influx to the district centers is an indication of the numbers who want to escape the hardships of subsistence-level living on the outer islands and who want a part of the new economy and life-style. These people have found life at the subsistence level unacceptable.

One of the most attractive sights to outer islanders is the approach of the field trip ship, not simply because the ship may bring news or needed medicine and school supplies, but because the ship also brings imported goods and foods. Outer islands' people and their economy do not produce such commodities as cigarettes, coffee, tea, sugar, rice, flour, clothing, or even beer. These are basic needs and necessities of the Micronesian people. Their subsistence economy cannot produce these items. The island economy does provide a few limited items such as taro, breadfruit, coconut, fish, chicken, and so forth. However, Micronesians have come to like and demand certain commodities that only the Western life-style can provide. This desire for imported goods has a determining effect on the kind of life and society the people want and even on the choice of a political future. Any political alternative which can best answer these demands without compromising the Micronesian desire for self-government and self-respect will have no difficulty in winning the hearts of the people of Micronesia, especially the hearts of those living on the outer islands. 
NOTE

1. Masaaki Kosaka, "The Intellectual Background of Modern Japanese Thoughts," in The New Asia (New York: The American Library, $1965)$, p. 372. 


\section{If we open a quarrel between the past and the present, we Agents sball find that we have lost the future. \\ of \\ Change \\ - Sir Winston Churchill \\ Speech, House of \\ Commons, 1940}

THE PROCESSES OF CHANGE in Micronesia are largely the product of the revolutionary changes provoked by the impact of modernity upon the structure of traditional Micronesian societies, and upon the values and belief systems of a people conditioned by an entirely different historical experience.

These changes are so many, so complex, and so variant that it is possible to focus only upon a limited number of them, namely, urbanization, secularization, commercialization, and Western education.

The impact of Western civilization, especially twentieth-century Americanism, has been great to the extent that it dislocated the fundamental bonds of the traditional societies and set in motion many processes of change. The accepted Western characterization of the traditional Micronesian society as static is on the whole an accurate one. The weight of historical evidence seems to support the view that in general it is the shock and continuing aftereffects of contact with more advanced socieries that first cracks and then breaks up the traditional social structures of what have been called the underdeveloped countries. ${ }^{1}$ And Micronesia is an underdeveloped country.

Micronesia had remained essentially unchanged for countless generations. The influences of Spanish, German, and Japanese rule were not strong enough to cause a dramatic influence upon its traditional societies. However, it would be wrong to conclude that there were no seeds of change, no potential for modernization, sown at that time in Micronesia's "traditional societies themselves." 2

"Nations, like individuals, are products of heredity and environment, although in the case of nations heredity is to be sought not in the 
genes but in the social heritage which flows from generation to generation to give some national content to men's minds." 3 What is significant in this statement is that the environment enters into this heritage to change the direction of the national stream and to enrich or diminish it.

Over the centuries the legacy of the Micronesian peoples has been diverted into new channels by the colonial experience. Thus, the gradual passing of traditional society from these Micronesian islands is in fact the passing of many traditional ways of life. All movements of social change alter the ways in which human beings live out their daily rounds. The process of modernization powerfully transforms individual lifeways. ${ }^{4}$

The move from the familiar and deeply interpersonal life of a family farm or land in an isolated village or island to the strange impersonality of a "job" in a busy city or crowded district center with unknown persons is one such transformation"-perhaps the one that is most often experienced by individuals exposed to the modernization taking place in Micronesia today.

It is often customary to relate these changes to the policies of the colonial powers, but to do so would be to overlook many of the fundamental problems that the Micronesian societies encountered in adjusting to the modern world. Borrowing or diffusion is not an automatic process. Out of what is offered by the other society a choice is made, determined by many complex factors. This is what Métraux and Crouzet asserted in their book, The New Asia. The same is very true of Micronesia.

Not very long ago it was common for anthropologists and government officials to look with some degree of dismay at the acculturation process, or at the changes that brought a backward people nearer to the Western pattern. They insisted that Micronesians should stay where they are, that they would be happier that way. "This may possibly have been a reasonable position at one time, but, if so, that time has long since passed." 6 The revolution of rising expectations in Micronesia today is unparalleled in all its history.?

Micronesia can be advanced and modernized at a pace much faster than its present one. Americans in Micronesia, both in civil service and privare institutions, have been a stumbling block to a certain degree. Government decision-makers have vacillated among the priorities set by military considerations and native welfare and the ideals of the United Nations charter. The private sector has tried to preserve the institutions of the native peoples, believing that wholesale emancipation would bring 
chaos. No one is absolutely sure what the future goal will be; thus the attitude of "wait-and-see" has been adopted.

Furthermore, there is little instinctive knowledge of the transitional process on the part of many Americans in responsible positions. It is true that the American national experience did help Americans gain some insight into the process of transition, but the United States as a whole developed in a virtually empty continent mainly from British social and political foundations; and the British who moved to the United States in the seventeenth century came from a society which had already gone far along the road to modernization. ${ }^{8}$ To some extent the same can be said of the Americans in the United States Trust Territory-they have not been deeply touched by the experience of transition in Micronesia. Those who have are in the minority.

Americans are part of a society lucky enough to be "born free"; a society that did not have to struggle against the weight of attitudes, values, and institutions that accompany traditional societies. ${ }^{9}$

This is by no means an indictment of the United States administration, but if Micronesia is to move forward, it is very important that the administration grasp the meaning of this transition from a traditional to a modern society and what it means for the people experiencing it. Only after understanding this can the administration formulate sound policies that are conducive to the modernization process.

Among the Micronesians, the small number of Westernized and educated elite play a disproportionately powerful role. It is their duty to bring the mass of citizens into the mainstream of change in the modernization process. If democracy is eventually to emerge, the citizens must come to accept its responsibilities, among them the power to determine who shall govern and what the direction of public policy shall be. ${ }^{10}$

In any case, in the four principal areas in which the modernization process has occurred, the "moving forward" has been almost entirely of its own. Though slowly, modernization is still taking place.

The basic shift to urban life, new attitudes of secularization, acquiring of Western education, new ways of bargaining with moneyall are beginning to put an end to landowners as a class and to cut down tribal prerogative, giving new rights of freedom of thought and opinion.

\section{URBanization}

The process of urbanization ${ }^{11}$ commands special attention because of two facts: urban centers (district centers) have been the principal 
arenas of acculturation and Micronesian politics are primarily urban politics or district politics.

The rural areas have historically been the least and the district centers the most Westernized part of Micronesia. In a real sense, the rural dweller who moves to a district center takes a long step toward becoming Westernized. Urban life is not entirely a new experience for most Micronesians. ${ }^{12}$ The new urban centers established under American administration have accelerated the intensification of the division of labor. As Micronesians became increasingly dependent upon their occupational specialties or salaried jobs they lost the economic security of lineage and the self-sufficient rural community.

The impersonality and competitiveness of life in the district centers accentuated their personal insecurity as well as their individualism, which became more pronounced as they sought status and prestige within the urban life and social structure of the district centers. ${ }^{13}$

The process of districtization has been the strongest factor in breaking the ties of Micronesians to their traditional modes of life. It has produced the new elite society that dominates the politics of the various districts in Micronesia. Indeed, the territorial politics of the districts is largely limited to those within the centers. And as the most Westernized elements of the society, members of this elite are the ones most responsible for shaping future policies and hence the future development of Micronesia.

In the West the modern city is a function of industrialism; in Micronesia the district centers are based on commercial and administrative activities. Yet in Micronesia people are being attracted to the centers with the expectation that they will be able to find a way of life and a standard of living that are dependent upon industrial and commercial development. Also, people are being pushed toward the centers because of the bankruptcy of the peasant economy, brought about by the pressures of migration and commercialization.

The centers produce the territorial leadership, the people most infuential in defining the expectations of Micronesia as a whole. Furthermore, the centers have become a place of intensive acculturation, for it is here that Micronesians come into daily and intimate contact with all aspects of modernity. From every aspect, districtization, with its attendant problems and attractions, is a major acculturating process in contemporary Micronesia and a principal means of Westernization.

The process of districtization has produced three groups who are now the most important elements in Micronesian politics: the current Westernized leadership, the restless, aspiring younger generation, and a 
third group which has continued ties with both the centers and the rural areas and migrates back and forth between the two. It is this group that serves to bring urban political ideas and news of the Western world to the rural areas.

Districtization has led to an extraordinary problem throughout Micronesia, that of making the political process in the district centers far too Westernized, while the bulk of the population is still village-based and provincially oriented.

\section{Secularization}

Generally speaking, Micronesians are a religious people. The Marianas and the Western Carolines, Yap and Palau, are strong in Roman Catholicism, but have a minority belonging to certain of the Protestant sects. The Eastern Carolines, Truk and Ponape, and the Marshalls are bedrocks of seventeenth-century New England Puritanism, but have a minority of Roman Catholics. Thus, essentially Micronesia is a Christian country.

Traditionally, Christianity was the basic bond between the colonizers and the colonized. The introduction of American rule, whether direct or indirect, weakened and eventually destroyed this tie. ${ }^{14}$ This is not to suggest that all phases of life in Micronesia are now dominated by secularism. Throughout Micronesia there are strong elements advocating a stronger religious influence or a return to a life based on religious principles. Most recently, however, the emphasis of secular leaders in government has taken a shift that represents almost an attempt to establish new emotional bonds between government and citizens.

In many ways the Western impact has greatly narrowed the social and political scope of religion and its hold on the people. Secular education has weakened the family ties. The change from village to urban life has also contributed to a decline in the formal position of religion in the lives of Micronesian peoples.

In the rural areas, religion still remains one of the principal bases of social identification. In this sense, even if secular institutions have been replacing religious ones as the dominant sources of social control, ${ }^{15}$ religion remains an important factor in the social and political life of Micronesians. Indeed, no politician, however successful, can dare go to a rural village wearing all the banners of modern secularism and expect to win a substantial majority of the votes. To do so would be to commit political suicide, for, in facr, it would be viewed as a "curse" upon and an insult to the pride and dignity of a village. 
As a consequence of colonialism and, most recently, of Americanism, values, human relations, and institutions have been greatly secularized. Ironically, one of the most powerful of the forces furthering the process of secularization has been Christian activities. To most Micronesians of the younger generation, the church, both Roman Catholic and Protestant, represents the last of the attempts blocking the road to advancement and modernization. Because the church has been too conservative and too fundamental in its approach to the problems of contemporary Micronesia, the youth of Micronesia, in rebellion, have fled to the government schools and bureaucracies, and in general have adopted a more secular atritude toward everything.

The attraction to the "idea of progress" is not limited to Africa, Southeast Asia, the Near East, and other parts of the non-Western world. The islands of Micronesia have also been greatly affected by it. "At the core of this idea is the strong conviction that progress is inevitable, and that man can creatively master and shape his own destiny through application of the scientific method, the exercise of his ever-accumulating wisdom and ever-growing rationality." 16

In Micronesia, the shift from traditionalism to secularism has increased in pace during the past twenty years. Also, it has occurred very unevenly among the six districts and among different individuals because of the variable character of their cultures and personalities and their uneven exposure to the forces of modernity.

In certain spheres of activity secularism may be dominant; in others there may be uncritical acceptance of the traditional. Micronesians have deep commitments to traditional symbols and sanctions in certain matters, but the newly acculturated Micronesians are rapidly moving toward greater secularism.

One of the basic characteristics of this move toward secularism is illustrated by the Micronesian politician who, on the one hand, attacks those elements in his tradition which impair territorial unity, economic progress, and social modernization and, on the other hand, praises his tradition for the sense of cohesion which it creates. ${ }^{17} \mathrm{He}$ executes public policies toward secularizarion and pays lip service to his past. Indeed, secularization has weakened the traditional past and strengthened progress toward the future.

\section{Commercialization}

In Micronesia the process of urban growth, the changes in social stratification, and the emergence of more secular norms of behavior all reflect in large part the impact of Western commercial and economic 
institutions on the whole. This is the first and perhaps the last attempt by Micronesia, as a whole, to pull itself out of a static past into the mainstream of the twentieth century.

The Micronesians know that if their underdeveloped country is to overcome its chronic poverty and backwardness, they must acquire tools, fertilizers, roads, factories, power stations, and other materials of modern production. For a long time the Micronesians did not appreciate, at least until recently, the necessity for far-reaching social changes in all the areas in which human beings relate to each other: political; economic, including systems of land ownership and use, marketing, and finance; the patterns of family life; and the ideals or values which determine what people strive for. ${ }^{18}$

Today, among the most fundamental of the changes sweeping through Micronesia and bringing about new social relationships is the rapid shift from an almost wholly subsistence economy, based upon the cooperative bonds of lineage, to a dynamic money economy based upon cash, individual profit, and wage employment.

This shift has weakened the lineage attachment and given birth to new social classes, created new values and opened new opportunities and methods of accumulating wealth and acquiring prestige. ${ }^{19}$

Commercialization in Micronesia has, in general, accelerated the processes of districtization, secularization, and expansion in the scope of the political community. Another reason for the dependence of modernization on commercialization is that it is one of the key factors causing the changes in values, motivations, and aspirations that are associated with the process of modernization.

Commercialization is not simply confined to the private sectors of the economy alone; government has subsidized many programs and projects. Furthermore, government bureaucracies have attracted people to the district centers in the hope of finding economic opportunities. Thus, government, by creating these economic opportunities and subsidizing many local firms, has given the people throughout Micronesia the feeling that they too might enjoy a higher standard of living. This, however, is not to suggest that government solely is providing the basis for an expanding economy.

In summing up, trade and commerce have been among the major vehicles of Westernization throughout Micronesia for at least the past twenty years. They have operated in many ways; for one, commercialization stimulates trade contacts nor only with the ourside world, bur within Micronesia itself.

Land has always been regarded by Micronesians as the chief source 
of wealth, in fact the only major source. By generating an alternative major source, trade and commerce challenge, and change, the economic positions of the land and the landowners. Thus, the relationship between commercialization and Westernization throughout Micronesia is indeed powerful and should not be underrated. ${ }^{20}$

\section{Western Education}

"Development is a state of mind, and people have to develop themselves before they can change their physical environment and this is a slow process." 21

American education has been the most revolutionary of all the influences operative in Micronesia since the end of World War Il, and indeed since the imposition of Western rule. It has been the chief instrument in the creation of a class destined to rule the future of Micronesia. Western education has created this new Micronesian elite. $^{22}$

We cannot discuss Western education in Micronesia without brief mention of the role of Christian missionary societies. Micronesia was attractive to the missionaries, their main targets the heathens of Micronesia. In early contacts, the missionaries assumed that the Micronesians were wicked and immoral, and limited in intellectual potential. Thus, they assumed a policy of limiting the education of the natives, except for religious education. Although they courted chiefs and their families in order to secure toleration of, if not support for, their activities, missionaries in general were indifferent to the future and status of their converts in these islands.

The great bulk of Micronesia's leaders today are products of government-sponsored educational opportunities abroad. Missionary societies have existed in Micronesia since the early sixteenth century, but while they taught the natives to read and to write, they never went beyond that until very recently.

The general effect of Western education has been spread quite evenly over all six districts. It has produced the main elements for public leadership of the Trust Territory. It has staffed the technical and administrative machinery of all the districts.

A Western education is viewed by most Micronesians as the vehicle providing admission into a new world in which power, wealth, and comfort are available to all. Thus, more and more Micronesians have come to depend in some degree upon effort and achievement in educarion. ${ }^{23}$

It has also encouraged the belief that success in school would bring 
substantial material rewards. Consequently, a Western education has been sought by most Micronesians, especially by those disillusioned members of the old traditional societies and practices.

In Micronesia, as in India or other former colonies, a college degree, or even a few years of college, has become so essential for most white-collar jobs that all who have had the opportunity have tried to attend a college or university. The bachelor of arts degree is a passport to a job and to membership in the elite.

The Americans, through their educational program, have introduced two very vital things to postwar Micronesia: Western knowledge and techniques, and a taste for the democratic way of life. And both of these have infinite potentialities. ${ }^{24}$

At one time illiteracy and ignorance among Micronesians were maintained by the Spanish, Germans, and Japanese, and even by some religious institutions, as political weapons to keep the natives down and to maintain the status quo. Western education, within the last twenty years, has made it possible to conquer these obstacles. Western education has also stimulated independent political judgment, skepticism, and reflection about the nature of freedom and authority. ${ }^{25}$ These are among the values that education in the Western tradition has given to the emerging Micronesians of today.

NOTES

1. Max F. Millikan and Donald L. M. Blackmer, eds., The Emerging Nations (Boston: Little, Brown and Co., 1961), p. 7.

2. $\quad$ lbid.

3. Rupert Emerson, From Empire to Nation (Boston: Beacon Press, 1960), p. 60 .

4. Daniel Lerner, The Passing of Traditional Society (New York: The Free Press, 1958), p. 76.

5. Ibid.

6. Guy S. Métraux and Francois Crouzer, eds., The New Asia (New York: Mentor Books, New American Library, 1965), p. 18.

7. Other sections of this book treat the subject of "rising expectations" in much greater detail.

8. Millikan and Blackmer, Emerging Nations, xi.

9. Ibid., xi-xii.

10. Ibid., pp. 22-23.

11. Urbanization is identified with the district centers of Micronesia, and henceforth is referred to throughout this chapter as "districtization."

12. Most Micronesians experienced this way of life during the German and Japanese administrations. 
13. Gabriel A. Almond and James S. Coleman, The Politics of the Developing Areas (Princeton: Princeton University Press, 1960), pp. 270-272.

14. Ibid., p. 104 .

15. Ibid.

16. Ibid., p. 285.

17. See Almond and Coleman, Politics of Developing Areas, for a full treatment of the idea of "secularization" and its process in the underdeveloped countries.

18. Eugene Staley, The Future of Underdeveloped Conntries (New York: Frederick A. Praeger, 1961). For the Council of Foreign Relations. It is a good discussion of the economic siruation in underdeveloped countries.

19. Almond and Coleman, Politics of Developing Areas, p. 274.

20. See Almond and Coleman, Politics of Developing Areas, for greater discussion of "commercialization" in Latin America and other underdeveloped countries.

21. Staley, Future of Underdeveloped Countries, p. 203.

22. In the past, the Micronesian elite were of a hereditary class. Since the end of World War II, a new elite has emerged as a product of Western education.

23. Almond and Coleman, Politics of Developing Areas, p. 106.

24. Métraux and Crouzet in The New Asia. This book gives an interesting analysis of the impact of Western civilization on Asian countries.

25. William McCord, The Springtime of Freedom (New York: Oxford University Press, 1965), p. 245. 
The

Part 2 Micronesian

Inquisition 


\section{Contact with more advanced \\ 6. societies bas been, then, the principal force which bas \\ Micronesia's \\ Response eroded the structure and values of traditional societies. -M.I.T. Study Group Political Modernization}

\section{FREEDOM}

Since 1967, the pressures for greater freedom-social, economic, and political-have been mounting steadily throughout Micronesia. The desire for liberty cannot be equated with the simple need for bread, although freedom without bread would indeed be very difficult for Micronesia.

The "man cannot live by bread alone" dictum has great validity in twentieth-century Micronesia. It would seem that what the United States has been trying to do is to satisfy the hungry, needy man, while ignoring the inner man, the soul of the newly liberated man of Micronesia-the man who is thirsty for self-respect and human dignity. This is the man who can go without his daily bread if it means the loss of his freedom. This is the new man, the new being in Micronesia that one must reckon with.

This new man at this period in the history of Micronesia is demanding freedom and self-government. He has read about and knows Micronesian history; he is saddened by it, but as a man of reason, he understands and appreciates why Micronesia has come to be the way it is. Historical experience has helped shape it with little resistance from within.

The present round of negotiations between Washington and the Congress of Micronesia are the direct results of Micronesia's search and quest from 1961 to the present.

The quest for a greater amount of self-government has its origin in the Congress of Micronesia, but there were also individual Micronesians 
who, in their own small ways, had appealed for this right of increased self-government.

The 1960 s proved to be a decade of decision-making as well as dissent for Micronesia. It was during this time that most of those Micronesians who had gone overseas to college were returning and were giving momentum to the request for greater self-government and freedom.

The year 1965 marked a significant turning point in the history of Micronesia. The Congress of Micronesia was created and established. This body became a focal point of attention both in Micronesia and in Washington. The same Micronesian students and leaders who had earlier advocated a greater amount of involvement in their government were elected to the new Congress.

Within two years after the Congress of Micronesia was established, these men caused to be created the first political status commission. And with its inception the decolonization process began.

The Future Political Status Commission was created in 1967 for the purpose of determining the various political arrangements suitable for Micronesia. It was this commission's recommendation that Micronesia should seek a status of free association with the United States.

In 1969, the name of the commission was changed to Political Status Delegation to reflect the change in the nature of the body's work, which had changed from study to representing Micronesia in the first round of status negotiations.

In 1970, the name was changed once more and the body became the Joint Committee on Future Status, reflecting that the membership was composed of individuals from both houses of the Congress of Micronesia. Although this was also true of the membership of the earlier bodies, their names had not reflected this.

Despite the name changes, the groups are in fact the one and the same. There were minor changes in numbers only. The Future Political Status Commission had six members, one from each district; the Political Status Delegation and the Joint Committee on Future Status each had two members from each of the districts.

Under Secretarial Order 2882, as amended, of the Department of the Interior, the Congress of Micronesia was created and was given the authority to legislate on all rightful subjects of legislation. In 1967, the Congress of Micronesia passed Senate Joint Resolution 25, which empowered the newly created Future Political Status Commission to start charting a new political course for Micronesia. Subsequent select committees were created in 1969 and 1970. 
Decolonization is a logical response to an unresponsive authority. The impact of Senate Joint Resolution 25 is now being felt throughout Micronesia, and by the administering authority as well. In the process of decolonization, the Micronesians are asking that the very basic foundation of government in Micronesia be reviewed and upgraded. Even the whole United States-Micronesia relationship is being subjected to this process.

There is no doubt that the process of decolonization caught Washington by surprise. The whole reaction in Washington can be summed up in one small incident. In 1969, an official in the Office of Territories, Washington, had written to the administration in Micronesia inquiring as to whether the administration wouldn't be wise to veto Senate Joint Resolurion 25, which had already been approved and was in effect. This was rather ironic since normally resolutions are not subject to veto power.

In some countries, the process of decolonization has been peaceful; in others, it has been achieved through bloody revolution. This was the experience of the United States in its struggle for freedom from England. This process, that of self-assertion, is part of the right of self-determination. The right of self-assertion is recognized by the United Nations; it, however, is not a right easily available to everyone. What is available is the right to be liberated from alien masters.

After the machinery for decolonization was set in motion, it became clear that this would not be enough. The administering power was too slow in responding.

Because of this, the Micronization process was instituted. This process is simply a localization of positions within the government structure. For over twenty years, Micronesians had been promised time after time, that "if and when" any Micronesian is qualified, he would be promoted to a position of great responsibility. Such a policy is fine weighed on its own merits, but if such a policy were allowed to continue, the Americans would be in government and running the whole government for the next hundred years.

Basic to the Micronesian reaction is the fact that promise and bread alone are not enough to sustain any man who wants and needs a certain amount of dignity and self-respect. This is what Western education and religion has given to Micronesia, a sense of worth, a liberated self.

It is difficult to see how this decolonization process could have been handled any better than it is being handled now. Micronesians are fully aware of their own limitations. They are using only means that are proper and legal. True, there have been movements recently within and 
without Micronesia that are trying to encourage nationalism as the means to settle the political issue, but the Congress of Micronesia is the only authorized and legal spokesman of the people of Micronesia.

The leaders and the people of Micronesia are not so ignorant nor so nationalistic as not to take note of the fact "that the peoples whose imperialism or colonialism [they] condemn are also the peoples who gave to the world the principles which gives point to [their] condemnation." 1

As Professor Emerson, as quoted in chapter 2, has so rightly pointed out, colonialism is the bitterest enemy of the Western nations, but also it is their finest fruit.

In an inverse sort of way, this legacy is also true to a certain degree in Micronesia. The Micronesian self-assertion for greater freedom and autonomy is in itself a legacy of Micronesia's past years of domination by colonial powers.

This is the finest fruit of American colonialism in Micronesia. The right of self-assertion would never have been recognized nor achieved under either the Germans or the Japanese. It is the United States who informed Micronesians of their right to self-determination, and it would be difficult to think that the United States would look at this process in any other way.

Colonialism in Micronesia since 1965 has been a training ground for democracy and freedom as far as the Micronesians are concerned. This should be understood and appreciated by both Micronesians and Americans alike. What the Congress of Micronesia has been trying to do these past six years is amend colonialism in Micronesia.

The Four Principles

In 1970, by a Joint Resolution, ${ }^{2}$ the Congress of Micronesia set forth the following principles and legal rights of the Micronesian people:

1. That sovereignty in Micronesia resides in the people of Micronesia and their duly constitured government;

2. That the people of Micronesia possess the right of self-determination and may therefore choose independence or self-government in free association with any nation or organization of nations;

3. That the people of Micronesia have the right to adopt their own constitution and to amend, change or revoke any constitution or governmental plan at any time; and

4. That free association should be in the form of a revocable compact, terminable unilaterally by either party. 
The Congress of Micronesia believes and considers these principles and legal rights to be paramount and that they should serve as the basis for any future association between Micronesia and the United States.

\section{NOTES}

1. John Plamenatz, On Alien Rule and Self-Government (London: Longmans, Green and Co., 1960), p. 203.

2. House Joint Resolution 87, adopted in 1970 by both houses of the Congress of Micronesia. 


\section{7. \\ Self-determination}

The dwarf sees farther than the giant, when be has the giant's shoulder to mount on.

-Samuel T. Coleridge

The Friend

WHAT is self-determination? There seems to be a lot of discussion on the subject, but one wonders whether the average Micronesian or, for that matter, anybody knows and understands what is really involved when politicians and nationalists talk about the right of self-determination.

One thing is certain, wherever colonialism appears, the concept of self-determination will almost always appear. The two concepts are not complementary. In fact, one appears because of the other. It is a rare situation where self-determination appears without the prior appearance of colonialism. It can be argued that self-determination, as a concept, came about as a result of international concern, especially after the Second World War, as a safeguard against the forces of colonialism.

The most common meaning of self-determination, as understood in Micronesia, was proclaimed by and through the United Nations. The declaration states that "All peoples have the right to self-determination; by virtue of that right they fully determine their political status and freely pursue their economic, social and cultural development." I

In essence, self-determination is an act of free choice by a group of people officially determining how they shall be governed. If this is essentially true and acceptable, a question may be asked. Can a group of people, through the process of free choice, select a political future which is clearly nonindependent in nature? For instance, if Micronesia should decide, under United Nations observation and supervision, in an act of self-determination, unanimously, to become a territory of the United States, will the United Nations accept such a verdict as one that fulfills the act of free choice? 
Students, radicals, and other advocates of independence are becoming more and more vocal in their use of self-determination as a device to end American colonialism in Micronesia. What guarantee is there, however, that the people of Micronesia will exercise their inalienable right of self-determination in a plebiscite to vote in favor of independence as the first choice?

The opposite may turn out to be the choice and desire of the Micronesian people. From all indications, it looks like the great majority of the people in Micronesia have no real strong desire, at least at this time, to sever their present relationship with the United States.

Micronesia is a pluralistic society. There is no Micronesian language and, thus, no person can be called a Micronesian by virtue of the language he speaks. Collectively and culturally, there is a Micronesian person whose identity may be either Yapese or Ponapean. Bur there is no Micronesian identity. If Micronesia is politically established as a country, there may emerge a new identity.

The concept of self-determination has deluded many Micronesians into believing that all the evils of colonialism can be ended by the simple application of the magic formula of self-determination. Micronesia, being a multicultural society, will have to work hard to achieve self-determination in a way that will satisfy the aspirations of the six districts, not considering the various minority groups and clans existing within each district.

In addition, the United Nations, the respected world organization, has compounded the problem by championing the cause of all underdeveloped, underprivileged countries the world over, including the islands of Micronesia. In the case of Micronesia, the world body has yet to appropriate one single penny toward the betterment and improvement of Micronesia. On the other hand, the United Nations has done a lot by proclaiming lofty and majestic ideals declaring the right of all people, able or not able, to stand up on their own feet and be counted in an act of free choice, thereby letting the world know they are fighting colonialism, a staunch enemy of the United Nations.

There can be no question that the United Nations is performing a service in its campaign to end all forms of colonialism in the world. The world organization has been consistent in helping to liberate dependent and non-self-governing peoples. But the United Nations has given insufficient attention to the fact that the situations and conditions of regions desiring to rid themselves of the bonds of colonialism are not, by any measure, comparable.

For some mini-states or territories, and it is not certain whether or 
not Micronesia is excluded, the act of self-determination may not be a blessing but, in fact, would be chaos and suicide. For instance, one can admire the apparent love of freedom of the people of the island of Ujelang in the western Marshall Islands. But if they were to opt for complete independence from the present domination of the Marshall Islands District, such a move would result in starvation and perhaps extermination of the whole race of the Ujelangese people. Would such a result be acceptable under the rationale that it was initiated by self-determination?

Again the question is raised: What do we mean by "self-determination"? How do we reconcile the right of all peoples to self-determination and the survival of man as a human being, whether he is one of five or five hundred people populating an isolated island in the middle of the Pacific Ocean. And do those five or five hundred have just as much right to self-determination as the 2.5 million people in Papua New Guinea?

The working formula which has been used since 1946 in all the new stares that have achieved their independence after World War Il has imposed the following three main elements as basic ground rules: "(1) All dependent peoples are entitled to freedom. (2) The peoples so entitled are defined in terms of the existing colonial territories, each of which contains a nation. (3) Once such a people has come to independence, no residual right of self-determination remains with any group within it or cutting across its frontiers." 2

Under these three basic ground rules, once Micronesia decides its future political status, whether it be independence or otherwise, no districts or outer islands will have the right to appeal to self-determination as justification for a move which might disrupt the "national unity and the territorial integrity." This clearly denies the right of a separate existence to any group of people within the new nation of Micronesia, whatever political form it might take.

The doctrine of self-determination is, in essence, a doctrine of revolutionary change since it authorizes fundamental changes in the sources of traditional identity and political power.

This provision for an orderly succession from colonial status to a new order rests on shaky foundations as far as Micronesia is concerned because such a procedure would disrupt the inner unity of the six districts. How would the Marianas, or Truk, or Palau fare under such a situation? Equally important is the question of the welfare of the ethnic groups within each of the six districts. There is no guarantee for the protection of minority groups after self-determination is achieved. The irony of the situation is that the "assertion of the universality of the right 
of all dependent peoples to full and free self-determination sits starkly side by side with the equally uncompromising denial of such rights to groups within their frontiers." 3

The Micronesian peoples are on the threshold of their first act of self-determination. Yet, the political arena is far from settled. There is no major consensus among the people favoring either a choice for themselves or for any particular group or any ethnic minority group. There was a new political group formed in 1971 which favors independence as a political status for Micronesia; there are those who favor some formal association with the United States; there are those who want to maintain the status quo; but the great majority of the Micronesian people simply don't know what is going on and perhaps could not care less one way or the other.

Those who are seriously concerned about Micronesia's future should she opt for free association with the United States, or any other type of political status, must equally show some concern for the very act of self-determination itself.

Self-determination is that one stroke of the popular will expressed through a referendum. Once the votes are cast, there is no returning. The result of self-determination will ultimately determine the future political life of Micronesia, the kind of life and society one will have to live with.

However, the United Nations' Committee of Twenty-Four has generally recognized that "within the framework of the broad principles of the right of self-determination and independence, for all dependent territories irrespective of size and population, there are special problems when a very small territory is concerned, and the United Nations has special responsibilities." 4

Such responsibilities include taking the appropriate steps to ensure that the people of these small territories, such as Micronesia, are able to express themselves freely on their future status and with full knowledge of the options open to them.

There are some misconceptions which relate to small territories, many of which have given the impression that independence is the only way out of colonialism acceptable to the United Nations. This is not exactly so. In certain instances, however, the United Nations Committee on Decolonization has expressed the view that it should be possible for certain small territories to unite with others, to form an economically viable state.

If Micronesia should opt for a closer alliance with the United States, there is nothing to show that the United Nations would not agree 
to this form of decolonization, rather than the attainment of full independence, if it is satisfied that this is really the clearly expressed wish of the people of Micronesia.

There will be only one act of self-determination available to Micronesia. It will have to be in the form of a national referendum, and the result will clearly spell out the ultimate status of the new Micronesia. Acts of self-determination on the part of individual districts will certainly not be acceptable to the United Nations.

As Professor Rupert Emerson of Harvard University has clearly pointed out,

. . f far from being a universal and easily available right, the right of self-determination has in fact only on rare occasions been made available to certain peoples under special circumstances. It has occasionally been asserted as one aspect of the right of revolution, in which case its legitimacy is likely to be measured in terms of its success. . . . In its immediately present incarnation, the loudly proclaimed right of all peoples of self-determination must actually be read to mean that all overseas colonial peoples have a right to be liberated from their overlordship of their alien white masters. Once each non-self-governing territory has won its independence, its national unity and territorial integrity are not supposed any longer to be subject to attack by any within or without who might assert a claim to continued access to a right of self-determination for themselves. ...

What emerges beyond dispute is that all peoples do not have the right of self-determination. They have never had it and they will never have it. . . .

In the case of Micronesia, with its "mini" position in the world, its physical isolation, small land area and population, and the strong possibility of secession and fragmentation in the future, no clear-cut solution to the problem of self-determination is available. For instance, the following question is raised: To what extent can the people themselves, alone, either unilaterally or as equals in negotiations, decide to change their status? The answer will be different for independent states, or states in association, or for protected states than it will be for non-self-governing territories where changes in status must be granted or agreed to by outside authorities having unilateral or veto powers on the subject.

There may be cases where self-determination and secession appear 
to converge. For example, is Anguilla a secessionist territory in the unitary state in association with St. Kitts-Nevis-Anguilla, or is it a portion of the non-self-governing territory affirming its right of self-determination? There should be a distinction made between the self-determination of a subunit which has not yet any recognized status and an area which has such status. The latter does not have to prove its right to self-determination. The former does.

The Marianas, Yap, or Truk may have no difficulty proving their independent right to self-determination, but the ethnic groups within these districts may have great difficulty in making their case for self-determination.

With respect to fragmentation, which may eventually cause great problems in the Trust Territory, it must be asked to what extent is self-determination always compatible with territorial integrity?

According to paragraph six of U.N. Resolution 1514, "any attempt aimed at the partial or total disruption of the national unity and the territorial integrity of a country is incompatible with the purposes and principles of the Charter of the United Nations."

Micronesia as a unitary state can resort to the letter and spirit of this resolution to assert its claim of territorial integrity, if and when fragmentation is contemplated by any of the major districts of Micronesia.

Any district that is contemplating secession from the Trust Territory union would have great difficulty proving its case before the United Nations and the people of the Trust Territory as a whole.

Outside of moral considerations, there would be little room for maneuvering in the context of legal considerations, including precedent and practice as far as the United Nations is concerned. The five districts of Micronesia, whether individual districts like it or not, have every legal right to claim and to hold on to any district that may want to secede.

The bargaining position of the Micronesian negotiators may have been considerably weakened by the Marianas' embracing of U.S. militarism with open arms and desiring to join Guam. However, the Micronesian negotiators are pressing their case by arguing that the Marianas secession is clearly disrupting the national unity and the territorial integrity of Micronesia. The United States would be hard pressed to dispure such a claim because she is conducting separate negotiations with the Marianas.

Clearly, independence is a crucial point in the evolution of any dependent peoples. But it is a relative concept, subject to various interpretations. As far as the United Nations is concerned, independ- 
ence is not the resulting status, but the fact of free choice. If the people of Micronesia at a given moment are given a free choice of options, including the possibility of "going it alone," this would mean that they have enjoyed a moment of independence, irrespective of what their final choice may be.

Real self-determination by U.N. definitions is therefore at least synonymous with temporary independence. This aspect is more important to the United Nations than the classical notion of independence. However, unless the people of Micronesia have the unlimited and absolute right to determine what future status they want, they will never have exercised true self-determination. If lasting independence is not one of the available options, self-determination will have been denied.

The moment of self-determination in Micronesia is approaching rapidly, and it is more than essential that these various points of the right of self-determination are clearly understood.

NOTES

1. The United Nations Declaration of the Granting of Independence to Colonial Countries and Peoples.

2. Rupert Emerson, Self-Determination Revisited in the Era of Decolonization. An Occasional Paper in International Affairs (Cambridge: Harvard University Center for International Affairs), no. 9, December 1964, p. 28.

3. $\quad$ Ibid., p. 32.

4. "Status and Problems of Very Small States and Territories," UNITAR Series no. 3, U.N. Institute for Training and Research, N.Y., 1969, p. 17.

5. Rupert Emerson, Self-Determination Revisited, pp. 63-64. 


$\begin{array}{rr}\text { 8. } & \begin{array}{l}\text { We cannot preach self- } \\ \text { determination in Africa and } \\ \text { Asia wbile denying it to the } \\ \text { Reoples of our own island } \\ \text { dependencies, small as they are. }\end{array} \\ \text { with } & -\mathrm{D} \text {. W. Wainhouse } \\ \text { Destiny } & \text { Remnants of Empire }\end{array}$

THE SEARCH for an ultimate political status for Micronesia-the Trust Territory of the Pacific Islands, as it is presently named-got formally underway in the summer of 1967. At that time the two houses of the Congress of Micronesia-the Senate and the House of Representatives-adopted Senate Joint Resolurion 25, which created a Future Political Status Commission, "to insure ... [that Micronesians] are fully cognizant of the issues involved and the range of alternatives open to them with respect to their future political status." ${ }^{1}$ The commission was directed: (1) to determine the most suitable political alternatives; (2) to undertake, and recommend procedures for, political education; (3) to recommend means for ascertaining the wishes of the people; and (4) to prepare a comparative study of certain other countries that had moved from dependency to self-government or independence.

When Congress adopted Senate Joint Resolution 25, few Micronesians, if any, realized what an impact it would have on the future of the Trust Territory. Furthermore, it is doubtful whether anyone gave serious thought to many of its sociopolitical implications or to its likely effect on the Micronesian-American relationship. In fact, however, the adoption of the joint resolution marked the beginning of a new and decisive phase in the political history of Micronesia.

Micronesia's relationship with the United States and with the United Nations, the position of American strategic and military interests, and the funcrioning of the Trust Territory government itself-all have been affected by this joint resolution. In empowering the Congress of Micronesia to create its own commission to study and chart the political destiny of the islands, it can be considered as the first 
realistic attempt on the part of the Micronesian people, through their elected leaders in Congress, actually to begin the decolonization process in the territory. This was a very daring move, for-up to that time-the administration had neither planned nor proposed a study of the problem, and it is doubtful whether it could have been expected to do so.

The Micronesians had waited over twenty years for some sign that the Americans would institute a more intensive policy of development, and it is rather an understatement to say that they had finally lost patience. They came to realize that the United States policy of "gradualism" was, in reality, a policy of neglect. Micronesian leaders began to question the old attitude of "wait and see." They asked the question: "If other countries can achieve their objectives, why can't we?"

Micronesians had come to a point where they were tired of hearing promises with respect to the overall development of Micronesia. The administration was doing nothing substantial to develop the general economy of the Trust Territory. After twenty-two years its agricultural program was still in the experimental stage, and no commercial fishing industry had been developed. While there had been extensive and expensive studies made of the economic potential of Micronesia by independent, competent research firms, the administration had done practically nothing to implement their recommendations. Lands were being taken away for indefinite use-right by the military, and the people were not compensated justly. It must be remembered that land ownership in Micronesia is an acutely sensitive issue; in a subsistence economy, land is the only form of social security.

In the area of human relations, until 1973 the administration maintained a double standard (or dual system). This ran through all its activities-from creating segregated residential communities to granting housing priorities, from fixing pay scales to granting employee benefits and privileges. The continued existence of this double standard damaged the American image in Micronesia and made it difficult for Micronesians and Americans alike to develop a feeling of mutual coexistence.

Perhaps, because Micronesia is a "strategic trust," the United States has had every "right" to erect military fortifications, to condemn private lands for military use; but its maintenance of a double standard in nonmilitary dealings is without right or reason. Till recently, the concept of Micronesia as a "zoo" or "museum" flourished, as a consequence of the official policy of keeping the people within the boundaries of their islands. The few students who were so fortunate as to go abroad for study were limired to a two-year program and were 
forced to return to the Trust Territory at the end of that period. Ordinary citizens and businessmen were not encouraged to travel; obtaining a passport was very difficult. This policy now has been somewhat modified. But its application in the past has crippled Micronesia by denying its people the chance to learn and to gain wider horizons by visiting the world around them.

The people of Micronesia have become dependent on the administration for almost everything, because United States policy has made a "pensioner" state out of Micronesia. Improving the people's welfare without corresponding advances toward self-government or independence has stirred up criticism and has created discontent among Micronesian leaders and members of the Congress of Micronesia. This general feeling of dissatisfaction was well stated by a United States congressman who recently toured the Territory. He said, "Twenty years of mismanagement and bungling that is what our record is in the Trust Territory." 2 This confession inspired a former Micronesian senator to remark,

We are in the midst of the twentieth century. The last vestiges of colonialism are disappearing. We Micronesians are proud of our rich cultural heritage. We have found a new political awareness with the creating of our Congress. We are gaining confidence in our ability to govern ourselves. $^{3}$

While the world spotlight of anticolonialism and decolonization remains sharply focused on the larger areas in Africa and Asia, the fact remains that there is anticolonialism, if not antipathy toward the Trust Territory administration, in Micronesia today. The status commission was not created as a device to oppose the Trust Territory administration, but it has become the focus of frustration and impatience among Micronesians and has thus acted as a catalyst for the expression of such thoughts in public. This whole range of problems and attitudes is what Dr. H. A. Freeman had in mind when he wrote:

The fundamental principle of Trusteeship is that the

Trustee cannot profit at the expense of the beneficiary; it must exercise extreme good faith; it must do everything for the beneficiary's best interest; it must always account for what it has done; the trust must come to an end when the purpose of the trust is fulfilled and the beneficiary can take charge of its own affairs. ${ }^{4}$ 
In principle, the status commission supported this position. The commission also felt the people's sense of frustration, but it realized that it had to go a step further than just complaining. It determined to come up with an answer and to draw up a plan for the future. Whether the Trust Territory administration liked it or not, the status commission was an agent of change; it was there to stay, and it ran its full course until the mandate given to it was fully accomplished.

The creation of the Micronesian Future Political Status Commission, under the able leadership of Senator Lazarus E. Salii, of Palau, attracted great attention not only in Micronesia, but in the United States Congress, the United Nations, and among the American public. Since November 21, 1967, when the status commission held its first meeting, witnesses have appeared before it, some as advisers, some as representatives and advocates of the "United States-Micronesia Partnership" concept-a concept that has never failed to impress members of the commission with its extreme narrowness. Members of the Office of Territories of the Department of the Interior and of the United States Senate and House of Representatives have all, at different times, met with the commission and advocated some form of association with the United States. Almost every one of these government witnesses failed, perhaps deliberately, to mention independence as a possible choice or a realistic alternative that could be considered by the commission. Some form of association with the United States was always the predominant theme.

In the July Session of 1968 , the status commission presented its first Interim Report to the Congress. The report presented case studies of former island dependencies and outlined several tentative proposals with respect to future political alternatives. In general, it advised the Congress on the range and scope of these choices. The commission felt that it needed more time for its work and asked Congress to extend its life-a request that was granted in July of last year. The commission felt, furthermore, that it needed the services of an expert on the constitutional problems of Pacific countries. Professor J. W. Davidson, of the Institute of Advanced Studies of Australian National University, agreed to serve as a consultant. Upon his arrival in Saipan, in late January 1969, he immediately started a series of meetings with the commission. By retaining Professor Davidson, a New Zealander, the status commission eliminated several obstacles. First, the commission felt free to discuss with him a whole range of problems affecting the Micronesian-American relationship; and, second, he was free to dissemi- 
nate his views and opinions as a third party to the Micronesian-American debate.

Leadership and courage of a high order will be required of the Future Political Status Commission. The issues before it are many and complex. The overriding one, of course, is the quest for an acceptable political status for Micronesia. But questions of timing -in relation both to the progress of the commission's work and to the final selection and adoption of the new status-are scarcely less important. In Washington's strategic thinking, "Micronesia is a protective screen" between the United States and Asia;" and the commission is aware that there may be a massive move into the islands by American military forces, if and when they are asked to move out of Okinawa and Japan. Should the people of Micronesia delay too long, they may have to face what Senator Salii has called "the danger that the ballot [papers] for our plebiscite will be printed in Washington." 6

The moment of truth is fast approaching for the United States in Micronesia. Present indications are that the Congress of Micronesia will strongly oppose any move by the Unired States to take more land for military purposes, unless large sums of money are paid in return, as may be specifically provided in a formal agreement. The United States, for its part, has a combined moral and political obligation toward Micronesia. "At the highest level of policymaking, the administration is split wide open between the factors of military considerations and humanitarian considerations." " If Washington is not willing to cooperate and bargain, the status commission is likely to recommend that Micronesia should become independent at an early date.

The three major alternatives open to Micronesians that the status commission considered are:

Independence. The commission felt that the whole question of independence revolved around the problem of economic development. In other words, to what degree can an independent Micronesia become economically viable? I am of the opinion that there can be no sound and stable economic development till the political climate has cleared.

Free association. As a free associated state, Micronesia would be able to look to a metropolitan power for aid and assistance, as the Cook Islanders look to New Zealand.

Integration with a major power. The commission believed that such a relarionship with the Unired States would almost certainly involve the continuation of existing American policies toward Micronesia. ${ }^{8}$ 
Within the broad framework provided by these alternatives, many differences of detail and of emphasis are possible; but their relative merits could not be assessed till actual negotiations with the present administering authority began.

Senator Salii expressed the general feeling of most Micronesians when he said that he favored "a status which is similar to that between the Cook Islands and New Zealand-to be more specific I am thinking of a semi-independent state of Micronesia, loosely and very generally related or affiliated with the United States. It would mean," he continued, "internal self-government in Micronesia, it would mean that the government of Micronesia will be Micronesian, the executive branch of the government will be composed of Micronesians who will be elected by the people of Micronesia." 9

In its report, which was presented to Congress in July of 1969 , the commission recommended the calling of a constitutional convention with a large membership representing all sections of the Micronesian people. Through debating the various alternatives open to Micronesia, the convention would contribute substantially to the process of political education, both during its meetings and when its members returned home to share their knowledge with the people of their districts. In addition, it would perhaps provide guidance as to the questions to be asked in the plebiscite, which would determine Micronesia's future.

Many members of the administration have questioned the formation of the status commission and have asked whether it is necessary. Perhaps it is true that this action by the Congress of Micronesia suggests a feeling of ill will toward the administering authority on the part of the Micronesian people. But the reasons that necessitated an initiative by Congress are admirably suggested by some remarks of Theodore $\mathrm{C}$. Sorenson:

One of the basic flaws in our post-war thinking about world affairs has been our missionary zeal to assure a decent society to others. We have naturally assumed that our own political, economic and social system represents the desired standard of decency; and in a vain attempt to foster these standards, and suppress the standards of other people, have meddled in their internal affairs. ${ }^{10}$

Micronesians have generally accepted the view that this has been the basic flaw in the overall attitude of the Department of the Interior in its administration of the Trust Territory. The formation of the status commission reflects the general feeling of the Congress of Micronesia 
toward the government of the Territory during the past twenty-two years, a period marked by complacency and self-righteousness on the part of the Interior Department and the administration in their attitudes toward Micronesian problems. It also provides an answer to the question of how these unacceptable attitudes can be removed.

Many Americans have regarded the reference to the principle of self-determination as just another piece of political jargon accidentally included in the Trusteeship Agreement. To Micronesians, on the other hand, self-determination is a basic human right, a right possessed by all peoples, great or small, rich or poor, a right that no nation can justly deny to another. Preaching self-determination in the halls of the United Nations but failing to practice it in the field can be a dangerous political posture, in Africa or Asia-or even in relation to Micronesia.

\section{NOTES}

1. Senate Joint Resolution 25, of the Congress of Micronesia, adopted by both Houses of the Congress, 4th Regular Session, 1967.

2. Quoted in the Guam Daily News of Novernber 1, 1968.

3. Quoted from a speech by Hirosi Ishmael, the former senator from the island of Kusaie, given in the Senate during the 4th Regular Session, 1968.

4. Quoted from notes prepared in 1969 by Professor Freernan, for the Micronesian leaders. Freeman is an American jurist and professor in the Law School of Cornell Universiry. He was later retained for a period by the Congress of Micronesia as consultant.

5. Quoted in "Their Land Our Trust," an editorial in the Sunday Star-Bulletin and Advertiser, Honolulu, Hawaii, December 29, 1968.

6. Quoted from a speech given during the presentation of the "Interim Report" of the Political Status Commission to the Congress of Micronesia, 4th Regular Session, Saipan, M.l., July 1968.

7. Quored from my earlier work: "A Historical Study of Political Development and the Prospect for Self-Government in the United States Pacific Islands Trust Territory." An unpublished B.A. thesis, Pacific University, Forest Grove, Oregon, 1965, p. 102.

8. This opinion was expressed by the chairman of the commission, Senator (then Representative) Lazarus Salii, in the speech cited in note 6.

9. Quored from a tape-recorded interview, given during the general elecrion of November 1968. Senator Salii was then running for the senate in that election, which he won.

10. Theodore C. Sorenson, "Foreign Affairs," Playboy (January 1969), p. 90. Mr. Sorenson was a top aide to the late President J. F. Kennedy. 


$\begin{array}{rr}\text { 9. } & \begin{array}{l}\text { Modernization is a process, } \\ \text { based upon the rational utiliza- } \\ \text { tion of resources and aimed at } \\ \text { the establisbment of a modern }\end{array} \\ \text { Whociety. } & \text {-Claude E. Welch, Jr. } \\ \text { for } & \text { Political Modernization }\end{array}$

PRIOR to World War II, when Micronesia was under the Spanish, the Germans, and the Japanese, planning for Micronesia was always done by outsiders. Following the war, the American administration continued this process up until the time the Congress of Micronesia was created.

To a great degree, this practice was justifiable in the early years following the war because Micronesia was not then capable of assuming this kind of responsibility. However, in the more recent period, especially since 1960 , Micronesia has developed this capability, and yet the administering authority continues to display strong paternalistic attitudes toward Micronesia and her problems. This attitude in turn gave rise to stronger resentment among the educated indigenous leadership, a resentment which has been manifested in the actions and attitudes of the Congress of Micronesia since its creation.

As a growing and developing country, Micronesia became more and more resentful of the fact that important decisions were being made for the people of Micronesia without the input and participation of the Micronesian people themselves. Plans were developed in Washington, D.C., thousands of miles away, and people in Micronesia had to live with these decisions whether they liked them or not. Micronesians did not feel themselves a part of these plans and, therefore, could not embrace them with respect and appreciation.

Long-range planning is very essential, especially in a developing society, for those experiencing change. The Japanese, during their occupation of Micronesia, made their long-range plans many years before they came to Micronesia. True, their plans were Japanese oriented and for the benefit of the mother country, but at least they 
were long-range in nature and aimed at specific ends. This was the secret of Japan's administrative success. They were very clear about their main objectives and their policies were shaped accordingly.

Micronesians received little in the way of human and institutional development, but they were economically happy because they reaped the benefits of a large and strong industrial and economic base that the Japanese had built.

All human beings, whether advanced or backward, require some goals to work toward. The absence of any long-range plans means the Micronesians cannot formulate objectives to strive for. This tends to create a feeling of instability.

There are two ways of looking at the idea of long-range planning: namely, "planning for" and "planning by." The first starts with many experts identifying the needs of the Micronesian people and then proceeding to plan specific solutions for these needs. This approach is Western oriented, made by American experts who seem to know the particular needs of Micronesia. The difference between the Japanese and the Americans is that although the Japanese made similar decisions, they were at least sure about their overall objectives. On the other hand, the American administration is not at all sure. Until recently, Washington was not sure what it wanted to do with the future of Micronesia. The Congress of Micronesia has helped Washington develop its political objectives for Micronesia. The Trust Territory government, up to the time of the creation of the Congress of Micronesia, had been one which functioned on a year-to-year basis.

The "planning-by" approach is one which aims primarily at helping the Micronesian people identify their own needs and at encouraging them to develop their own solutions. The value inherent in this approach is to stimulate "planning by" the people; it cannot be expected to materialize when there are many competing specialized kinds of "planning for" by experts within the existing bureaucratic establishment.

One of the ultimate ends of the American administration is that of bringing democracy to Micronesia and preparing the people for self-government. In the "planning-for" approach, freedom and democracy are at a disadvantage, for they are not complementary to a developmental program in which people are being told what to do rather than being allowed to become part of the process of planning and doing. On the other hand, "planning by" is and can be a great asset to the development of a free, self-seeking, and self-confident society. This process would give Micronesians the will to learn how to stimulate 
constructive planning and action, and under it, with technical and economic aid, programs of development can go farthest.

The chief function of "planning by" is to give the people and their communities the desire, the impetus, and the method to use their own aptitudes to solve their own problems. The United States Peace Corps is based somewhat on this general approach to resolving the problems of underdeveloped countries.

The future of self-government in Micronesia depends in great part on this approach of letting people plan their own future. A country such as the United States, which zealously guards the rights and dignity of the individual, can and should realize the enormous advantage of such a program, provided it learns how to stimulate the necessary initiative, cooperation, and enterprise.

In contemporary Micronesia, the view is prevalent that the people, on the whole, want change. Planning must respect everyone's interest and be based on rationally conceived programs. In planning for the future, or for any change, people do not merely devise rational schemes, or ends, which are then realized by choosing appropriate means. The fact is that the plans, the ends, are themselves means; the plans enter into the texture of our actions and our thoughts as we transform or transfer the laws of society. ${ }^{1}$

Dr. Bennett says that the planner becomes part of his plans, and his personality, his integrity, and his responsibility are all involved in the course of events. ${ }^{2}$ Planning for change as well as for the future does not happen in a vacuum, but in a human society. People do not learn to do things by merely listening to proposals; they must become part of the planning process itself. Micronesians should be encouraged to become more active in planning their own political future, and in all changes that will affect their lives.

Planning for the future by the people of Micronesia would be a demonstration of the ability of man to exercise "choice over his destiny and affairs." 3 This philosophy is very much a part of the United Nations charter, especially its section on the right of self-determination by dependent peoples. The United States is very sensitive about the nature of the world struggle between democracy and dictatorship. The "planning-by" and "planning-for" proponents exemplify this very conflicr.

\section{Creative Innovators}

Ruth Benedict, in Patterns of Culture, said that there are two kinds of leaders, the innovators, who initiate change, and the influentials, who 
are followed by others. ${ }^{5}$ Here we are mainly concerned with the Micronesian innovators, the supply of influentials being plentiful in Micronesia, the latter composed mostly of chiefs, politicians, and business leaders.

Whether serving in government bureaucracies, or in public work projects, or in private business offices, creative leaders are needed by every society. Micronesia needs this kind of people. Furthermore, Micronesia must court the kinds of change that will bring enrichment and strength, not just any kind of change. There are changes that could destroy Micronesian society if they are not carefully screened, such changes as governmental imposition of change in native customs made without giving due recognition to local wisdom and district will.

While Micronesia must seek out the innovator, she must also be careful to safeguard what John Gardner spoke of - the importance of a society's continuity with its underlying purposes and values. These purposes and values are relatively durable and enable a society to absorb change without sacrificing its distinctive character and style. They ensure that a society will not be buffeted in all directions by every wind that blows. ${ }^{\circ}$

The Micronesian innovator is not simply one who contributes to a new way of doing things, he is also the one who contributes to a new way of thinking about things.

The innovators cannot operate in a society that is closed and rescricted, for creativity requires certain amounts of freedom in order to come to flower. It is a rare individual who has it in his power to achieve the highest reaches of creativity, but many could achieve fairly impressive levels of creativity under favorable circumstances. ${ }^{\text {? }}$

Innovators are often the objects of bitter attack and opposition all their lives. That is why innovative people often need protection, and why a strong tradition of freedom of thought and inquiry is essential to continuous growth in progress. ${ }^{8}$ The innovative Micronesians, until recently, have been ignored and not consulted. They should have been made part of the policy-planning process from the beginning.

The educated elite of Micronesia is, in a sense, an innovative group. They are revolutionary in character; they are demanding changes. Circumstances have thrown them into the role of opponents of the status quo and the Trust Territory bureaucracy, thus making them instruments of change.

Because Micronesia has long been a static society, there is a need for innovators who can help bring about changes and make plans for the future. Gardner states that no society is likely to renew itself unless its 
dominant orientation is to the future. ${ }^{9}$ This does not mean ignoring the past completely, but the society that is capable of continuous growth and renewal not only is oriented toward the future, but looks ahead with some confidence. This is to say that an attitude of hopelessness will not bring change. A society capable of continuous growth and renewal not only feels at home with the future, it accepts, even welcomes, the ideas that the future may bring.

The old belief that experience is the most important criterion for leadership is no longer true, at least this writer challenges that dictum. In the opinion of this writer, experience can be a liability, at least for the process of modernization.

The impact of modern science and technology with which the younger generation and its innovators are beginning to be identified has made the old experienced hand, who acts and thinks in the old ways, look somewhat obsolete. But many believe he must remain at the job because he is an experienced man. There must be a distinction made between the kind of experience that is an asset, and the kind that is a liability.

In Micronesia, there is no sophisticated electorate. Mass support has been won through the influence of dynamic and vital personalities. These men are not only influential, they are also innovators in a society that is changing and is being molded by the forces of modernization.

Progress in Micronesia has been slow in terms of human advancement. It was stated earlier in this book that people have to develop themselves before they can change their physical environment. This is a slow process, involving changes in relations between classes and races. It requires improvement of governmental organization and operations, and the extension of social institutions, courts, schools, and health services. These things take much longer than the building of a road, a factory, or a Congress office building. ${ }^{10}$

Habits of thought and conduct are the most stubborn obstacles to development." Tractors can be shipped to Micronesia, but to use them effectively to advance the well-being of the people requires a revolution in thinking, as well as the learning of new mechanical skills.

The economic productivity that can be attained through the tractor depends on having a large market for the crops it helps to produce, and this in turn demands drastic departures from the traditional system of local trading. ${ }^{12}$

McCord states that change is originated by the innovator from the outside, the person who does not believe in the usual way of doing things. He shows that men alienated from the old society (the Quakers 
in England, certain clans in Tokugawa Japan, the Puritans who came to the United States) have had important roles as innovators. ${ }^{13}$

Micronesia is experiencing its share of this kind of people. They are to be found in the younger educated elite who, since the end of World War II, have shown dissatisfaction more and more with the old ways of doing things.

Both old Micronesia and her trustee cannot long continue to deny the role of this change-seeking educated elite. They are performing the role of the innovator. They have a definite place in the society that is developing. They have a role to play in the private and public affairs of the society.

To deny them their role and their place is to deny progress itself. The trying of new and innovative ways, especially in Micronesia's formative stages of development, is very important and essential for her political future. These innovators are not simply artists, but also political leaders who have a great part to play in shaping the course of events throughout Micronesia.

\section{NOTES}

1. John W. Bennett, "Planning Change in Perspective," Human Organization, vol. 18 (1959), pp. 3-4.

2. Ibid., p. 3.

3. Ibid., p. 4.

4. Ellery Foster, "Planning and Community Development," in Human Organization, vol. 12 (1953), discusses in greater detail this aspect of government.

5. Ruth Benedict, Patterns of Culture (Boston: Houghton Mifflin, 1934), p. 19.

6. John W. Gardner, Self-Renewal (New York: Colophon Books, Harper and Row, 1964), p. 30.

7. Ibid., pp. 32-33.

8. Ibid., p. 33.

9. Ibid., p. 107.

10. Eugene Staley, The Future of Underdeveloped Countries (New York: Frederick A. Praeger, 1961), p. 203.

11. Ibid., p. 204.

12. Ibid.

13. William McCord, The Springtime of Freedom (New York: The Oxford University Press, 1965), p. 140. 


\section{During the long centuries of Oceanic bistory, they bave done Beyond Trusteeship it before. Perbaps, they will do it again. \\ -Douglas L. Oliver The Pacific Islands}

THE MICRONESIAN PEOPLE alone must decide on the quality of life they want for themselves now and in the future. Such questions as the following are pertinent: Does Micronesia favor a way of life modelled after the Oriental (Japanese)? Or is the Western (American, British, etc.) way of life desirable? Or are the Yapese, Trukese, Palauan, Marshallese, Ponapean, and Marianas ways of life the best? Or perhaps a blend of two worlds, or three, might be the better choice?

These are fundamental questions and unless they are clearly defined, understood, and determined at an early date, Micronesian political leaders are wasting their energies trying to formulate and decide upon the ultimate grand design for a future way of life, or even a future type of government, suitable and acceptable to the Micronesian people.

If and when a future kind of life is decided upon, the range of possibilities will be greatly narrowed, thus allowing the political leaders to work and think within a defined sphere of understanding or area of choice. However, in the absence of such a definite mandate from the people, the Joint Committee on Future Status is of the opinion that it can assume that, since Micronesians have lately lived under the American system of government and American way of life, this would be their natural choice, and there is merit and logic in this belief. The so-called American experience or orientation is a reality that must be dealt with. Almost all of the younger generation of Micronesians, born since 1945, are truly American oriented, and those who were born during the latter part of the Japanese era have had an American 
education. These two groups constitute about one-half of the population of Micronesia.

Some of those who were at least twenty years of age or older during the Japanese period are inclined toward the Japanese, but there are not many of them. In fact, many of this group are pro-Western; they were old enough during the Japanese period to see how brutal the Japanese were in their treatment of the people.

Whether Micronesia decides to opt for free association or independence, the inclination of the general public would be for some type of association with the United States or a Westernized nation. Micronesia, contrary to what some people think, is, by its colonial experience very much Westernized. Christianity is a form of Western colonization, and Christianity took root in Micronesia during the Spanish period and continued to grow during the German period. The Japanese spent over thirty years in Micronesia, but there is no Buddhism or Shintoism in Micronesia today. This fact alone has made Micronesia a natural breeding ground for Western ideas and civilization. Without any doubt, the roots of Christianity have taken firm hold in Micronesia.

The status committee would be negligent if it failed to consider this point in its negotiation. The saying that "you don't change horses in midstream" is very applicable in this respect.

There are those who think that Micronesia's political future lies in the Orient. While this position may be sound and may have merits, history does not support such a happening, nor does it seem a logical development. Micronesia spent only a short time under the Japanese as compared to those years in which the Micronesian consciousness grew and developed under the Spanish, the Germans, and now the Americans. Our only written literature, the Bible, is translated and modelled on the Roman alphabet; our God is the same as the God of the Christian world.

The pro-Japanese element in Micronesia is primarily made up of the business community and its allegiance appears to be motivated by profit, nothing else. Since Micronesia's economic posture is weak, this desire for greater involvement of Japanese business in Micronesia is important. But there are considerations orher than economic, of equal importance, and any decision on Micronesia's future must incorporate these as well.

Geography and Modern Technology

The problems of governing such a large area need further 
discussion here. There is no question that Micronesia's peculiar geography presents difficult problems. The political problems will not be easy to solve, but the operational aspect of the government and all its logistic requirements will be even more difficult.

The communication network and transportation system are going to play a key role in the success or failure of any future government in Micronesia. The transportation and maintenance costs will be enormous, but the entire system will have to be enlarged and service improved. With the availability of a communication satellite, there should be no reason why a complete telephone system cannot be installed. This is where science and technology can help provide the assistance that are needed to make Micronesia smaller and more governable.

The policy of personnel exchange in Micronesia's public service corps will have to be strengthened; this will expand Micronesians' knowledge of themselves and will help to develop a national consciousness. It is hoped that land ownership in Micronesia will be more easily accessible to everyone, and that travel between districts will be encouraged.

The Community College in Ponape and the Micronesian Occupational Center in Palau are going to be more important as a greater mixture of Micronesians come from every district to study there. These two institutions of higher learning will put in their share of bringing Micronesia closer together.

Science and modern technology, improved transportation and communication systems, exchange of personnel, development of institutions of higher learning within Micronesia-all these will help bring Micronesia together and hopefully make it more manageable. The cost of these undertakings is outside the scope of this work. Such costs will have to be looked at in light of what form of government Micronesia will finally choose.

Cultural and linguistic loyalties will present a problem in any future government. However, in view of the heterogeneity of culture and language, the furure government of Micronesia will have to confine itself to the use of the English language as the official and common medium of communication throughout Micronesia.

\section{Beginning of Political Unity}

The question of political unity in Micronesia had its inception in 1944 when Western concepts and political process were instituted under the military government. 
But in 1949, when the United States made its first report to the United Nations Trusteeship Council, it briefly outlined its plan for the political advancement of the Trust Territory. According to that plan, attention would be focused initially on the development of self-governing municipalities or local government units, then progressively the powers of district bodies would be increased, and finally territory-wide organs of self-government would be developed in which the indigenous population would play a substantial, if not a major part.'

The development of municipalities and district legislatures, then later the Congress of Micronesia, came at various times and stages of U.S. administration. These bodies first came into existence as advisory agencies and later were developed into bona fide law-making institutions. The point to remember is that these bodies brought the first element of political unity to Micronesia. They helped foster the feeling of belonging to a "club." Although they gave a somewhat illusory sense of belonging to and participation in government, they were, nevertheless, the initial training ground for most of the leaders in Micronesia today.

It was through these legislative "clubs" that the idea of a "Micronesia" actually developed and the idea gave rise to a sense of polirical unity among the indigenous leaders of Micronesia. Furthermore, it can be argued that the development of these legislative and advisory bodies did help transform the provincialism of most Micronesian leaders into a wider horizon of nationalism. The history of the development of actual nationalistic feelings cannot be covered without reference to the Congress of Micronesia, which is and has been the breeding ground for Micronesian nationalism.

At present, there is no territory-wide political party with membership covering all the six districts. Any government of the furure will have to encourage the development of national political parties if such a government is ever to capture the national scene and speak and respond as a representative of the people on a national level.

Political parties, although not fully developed in Micronesia except in Saipan and Palau, are almost essential to the kind of government that the Micronesian people are now used to. Further, they are part of and usually associated with representative government. Political parties would not be too foreign to the experience of Micronesians who, although they do nor openly publicize their party affiliations, do 
nevertheless have certain loyalties and strong affiliations in a traditional way.

A political party would simply be a group trying to gain or hold political power. Under either free association or independence, Micronesia would find that to run a fair and responsive government, she would need people who would be running solely on the merits of certain public issues and who would be elected to public office on that basis. This would help curb the tendencies in Micronesia toward favoritism and bribery in local elections. It would afford political office to men of imagination who would prefer to enter an election contest purely on the merits of certain broad national issues.

While there is no territory-wide political party at the moment, the Truk Independence Coalition may develop into a full-fledged party with membership in all districts. If this happened, opposition would soon develop, and another party would emerge to challenge the present Independence Coalition. There is a small element that opposes the Independence Coalition already developed in Truk. This and other elements of political feeling and thinking may join forces to form a real territory-wide party.

\section{Charismatic Leader and National Issues}

When Micronesia finally stands on its own, it will find that it lacks a charismatic national leader, one who has a capacity to inspire loyalty toward himself as the source of authority apart from an established status. Such a leader is needed to inspire a national following as Micronesia prepares itself to take on the awesome task of nation building.

There are several charismatic leaders in Micronesia but their attraction is presently limited to the district level and while they may have a following in other districts, such followings are small in number. However, this problem should be understood as an aspect of the geographic dispersion of Micronesia. The possibility of a national leader emerging soon is not too promising, but it surely is probable.

\section{Population and Resources}

Today, if one Micronesian is entitled to one breadfruit and one fish, within twenty years from now, that Micronesian will only have one-half of the same breadfruit and fish. This analogy is only half true, the situation may get even worse.

Nature has endowed Micronesia with slim resources and nothing 
in the way of a built-in mechanism to halt the multiplication of the Micronesian race. We must enlist the aid of science for that.

Herein lies the real dilemma of the Micronesian situation. The population of Micronesia, in the past twenty years, has never stopped growing. It is now slightly over a hundred thousand, and within the next twenty years, it is expected to double the present figure. The land area will remain the same, and food production, the number of breadfruit and coconut trees, will also remain at about the same level. What will and can Micronesia do? What is Micronesia's program and plan to meet the unchanging and fixed natural resources of Micronesia? How does Micronesia propose to feed her increasing population?

The "revolution of rising expectation" has already swept Micronesia. People are demanding better things and better services than they have ever demanded or enjoyed before. The gap between expectations and the reality of scarce resources, poverty, and a growing population is one dilemma facing any future government of Micronesia. Micronesia can no more change these high expectations than it can change its own history. Its only recourse is to change the opportunities for realizing the expectations.

\section{Posttrusteeship Government}

The postrusteeship government in Micronesia will not and cannot change too radically from its present form without incurring serious danger to national life and to the new government itself. Perhaps Micronesia will have to content itself temporarily with using the existing patterns, with the only exception being that Micronesians will assume the running of the entire government machinery.

Posttrusteeship government in Micronesia should have a reasonably centralized form of authority. The three branches of government will remain the same. Each will run independently of the other. Top positions within the executive branch will all be elective ones. The chief executive may continue to appoint his representatives in the district government. The idea of an elected district chief executive is antipathetic to the concepts of unification and centralization.

The Congress of Micronesia may have to continue in its present form. There will be little change, if any at all.

Other models of governmental structure should be acceptable, provided they do not radically alter the present experience. However, the American model of a presidential system of government should be examined closely. It may be already too late to try other models of 
governmental structure. The people of Micronesia are used to the present model, and, therefore, it is logical that it be continued with few minor changes, at least during the transition period.

The judicial system in Micronesia is primarily Micronesian in nationality except for the three High Court justices. It will be necessary for Micronesia to retain the services of qualified expatriates who may be willing to serve the Micronesian people, or find qualified Micronesians.

Between Micronesia's national aspiration and the economic and political realities, there is a big gap. Upon reflection, it is obvious that a choice is involved, but not much of one. Micronesia, after having been dependent upon nation after nation for centuries, has become almost a shadow of its colonizers. However, it has become apparent that Micronesia wants freedom, and with the immense responsibility of independence and self-government coming closer, Micronesia has become restless.

A new government must be created, instruments of government must be established, perhaps several languages besides English must also be learned, and a Micronesian army raised. Even a new set of moral and esthetic values may need to be chosen or the old ones reexamined.

But, there is a paradox-Micronesia's choice is very limited. What can Micronesia claim as its own except irs people and land? What is Micronesia if, in every step of the road to freedom, it must follow in the tracks of the exrulers? What kind of freedom will it be if Micronesia cannot forget its former masters, if Micronesians continue to speak their language, and imitate their dress? Why can't Micronesia reconstruct its ruins, and establish new principles, a new system of government? What is Micronesia's collective identity, if any?

Micronesia wants to build for herself an autonomous life, but what will it be based on? Can Micronesia really afford to go back to its past, to its subsistence economy? Is there anything in Micronesia which is wholly unique after centuries of colonialism?

There is quite a bit of myth about the whole Micronesian quest for identity and freedom. Most nation-states of the world have a single language, natural borders, and an admixture of ethnic groups less varied than Micronesia's. Micronesian nationalism clearly negates all minority groups and relations in Micronesia. Wouldn't the imposition of nationalism then be a myth since there clearly is no one dominant Micronesian identity? Wouldn't it be oppression, although of an internal sort?

In view of these unusual paradoxes, the new postrusteeship government will almost have to follow what is now available with only 
few changes; the major change, of course, will be the fact that Micronesians will run the government and guide the destiny of the new Micronesia.

Regardless of whether Micronesia opts for either free association or independence, Micronesia must make a choice as to the form of government it wants. In the interest of keeping a fairly cohesive and efficient government operation based on past and present experiences, the concept of centralization in the posttrusteeship government might be a logical one.

Under this concept all cabinets and district administrators are appointed, only the governor or the vice-governor will be elected. This arrangement will allow more loyalty and support to be given to the chief execurive who, in turn, is reponsible to the electorate.

On the other hand, there is the possibility of a confederation of the six districts of Micronesia. Each district would voluntarily join in a loose arrangement simply for political and economic reasons; otherwise, each district would be on its own and manage its own internal affairs. Its connection with the central authority would be for policy guidance and other external matters.

Under confederation, the district administrators would be elected, just like the governor, and while they would have no direct loyalty to the governor, they would be responsible to him for external political policy and for fiscal matters. If Micronesia should get an appropriation from an outside power, such as the United States, the line of connection between the district administrators and the governor would be that much stronger.

On the other hand, if the above arrangements do not accommodate sufficiently the circumstances and needs of Micronesia, the following three governmental systems are worthy of consideration by the people and the Congress of Micronesia. They are presented in a brief summary in the hope that they might encourage further discussion and consideration.

\section{Presidential System}

Due to the present political circumstances of Micronesia, and in view of the geographical dispersion of the six major groups of islands comprising Micronesia, the long history of cultural and ethnic isolation among the peoples of Micronesia, and, finally, the hard fact of disunity among the six districts, it would seem inevitable that a presidential system holds great promise that should be seriously considered in the government of posttrusteeship Micronesia. 
The head of state or the president in the future government of Micronesia must be responsible directly to the people rather than to the legislature, as is practiced in the Westminster system. He should be elected by the people. The nomination of candidates might be made the responsibility of the Congress of Micronesia.

The winner of this territory-wide election would become the first president of Micronesia. The same process would also be held for the office of the vice-president. Since these are the only two nationally elective offices, there should not be too much problem.

Such a manner of electing the president and the vice-president territory-wide would continue until nationally established political parties are formed or created with membership from every sector of Micronesia.

Under this system, it is expected that each district would also elect its own chief executive. Each district would agree to unite with the others to form a confederation or the United Districts of Micronesia.

In the legislative area, the present system as operated by the Congress of Micronesia would have to continue. The elected senators and representatives would be the first link berween the six districts and the national government.

The judiciary would be free from any political connection; the elected governor would nominate the required number of justices with the advice and consent of the Senate of the Congress of Micronesia.

\section{Westminster System}

Under this arrangement, the legislature or the Congress of Micronesia constitutes the legislative power. It is the supreme power in the new state of Micronesia.

The elected head of state or chief minister, together with his appointed cabinet, constitutes the executive branch.

The manner of electing the chief minister is different from the process utilized under the presidential system. The chief minister, under this system, would be an elected person like the rest of the members of the Congress of Micronesia; he would in fact be chosen from among the members of the newly elected Congress of Micronesia. By convention to be adopted, he and his cabinet would be collectively responsible to the legislative branch, and not directly to the people. He would have to resign if he lost the confidence of the legislative branch. 
The one advantage of this system is that it would cause very little problem or confusion in the election process; and, taking the problems of disunity and the lack of national political parties in Micronesia, this might speed up the process of selecting a national leader.

The new chief minister would appoint his cabinet either from among the members of the Congress of Micronesia or from those qualified outside the Congress of Micronesia.

The judiciary would be an independent branch. The members of the High Court would be appointed for life by the new governor with the advice and consent of the Senate of the Congress of Micronesia. Judges may not be members of the Congress of Micronesia.

\section{National Council System}

Under this system, the bicameral legislature, consisting of the House and the Senate, would continue in the Congress of Micronesia. The constitution of the new state of Micronesia would assign the executive power of Micronesia to a National Council of Government. The national council would consist of six members (representing each district) elected directly by the people of Micronesia in accordance with a system of equal representation from each district. The national council would elect its president. Thus, the president of Micronesia is, in fact, the president of the national council. Such a president would be changed every two years by a system of rotation within the national council. Members of the council would hold office for four years.

The advantage of this system is again related to the problem of unification and the geographical dispersion of the territory.

The national council would be elected and would not be responsible to the legislature or the Congress of Micronesia. The president of the national council would be responsible only to the national council and to the people of Micronesia. The manner of electing the president would be relatively simple. It would be by secret vote among the six members of the national council.

The president elected by the national council forms a government by appointing his cabinet; the cabinet would be directly responsible to him and the national council, not the Congress of Micronesia.

The judiciary would be similar to that of the presidential system or the Westminster system.

The national council system is both unitary and centralized, and 
can easily accommodate the idea of a confederation of the six districts or the desire for a reasonably centralized form of government.

NOTE

1. "Significant Events in the Development of Government in T.T.P.I." Office of Political Affairs, Headquarters, Trust Territory Administration, January 10, 1968. 


\section{II. ... therefore choose life, that \\ Free botb thou and thy seed may \\ live... \\ Association \\ -Deuteronomy 30:19}

THE WINDS that in the last decade brought great political change to many underdeveloped countries of Africa and Southeast Asia are blowing steadily and will continue to effect many great changes in Micronesia during this decade.

Today, after centuries of relative isolation and domination by the Spanish, the Germans, and the Japanese, and after some twenty years of American administration, Micronesians feel that a change in political status must be made in this decade. For all practical purposes, the 1970 s will be a decade of development and of decisions of profound and lasting consequences.

The Congress of Micronesia's Future Political Status Commission, after making extensive study trips to the islands of the South Pacific and to the districts of the Trust Territory to examine the question of Micronesia's future, proposed its recommendation for a state of Micronesia in free association with the United States. Furthermore, the political status delegation, which went to Washington in 1969 , also endorsed this position. Micronesia as a free and associated state would be a new governmental entity in the American system of federal government, but the concept is not a new one in worldwide governmental systems. West Berlin has a curious form of participation in the Federal Republic of Germany (West Germany); the European Economic Community (Common Market) of free and associated states of Western Europe share a common interest while retaining their own political independence; Puerto Rico is a free and associated commonwealth of the United States; and the Cook Islands has a free and associated status with New Zealand. This is a new emergent political 
status in the world for dependent peoples and for the liberation of colonial peoples who do not wish or may not be ready to organize themselves as independent political communities.

To Micronesians, what is basic to the concept of a free associated state is the question of ownership. Micronesians contend that ownership of the Micronesian islands rests with Micronesians. To exercise true ownership rights, Micronesians must be vested with certain powers of sovereignty. The question of "who governs" is related to "who owns the land." The question of sovereignty is very involved, and it should be understood that the Micronesian desire for sovereignty is derived not from a pecuniary motive; rather, it is based on the premise that a political alliance berween the United States and Micronesia, in which the Micronesians' rights of land ownership are respected, is a good thing, as opposed to the political subordination of Micronesia to the United States.

There will be mutual concessions by both parties involved. The element of friendship must be at the very core of the free associated state. There must be mutual respect. The free associated state is a compact among friends. It is hoped that under the concept of a free associated state, Micronesians will govern Micronesia. The report of the Future Political Status Commission states in part that "the aspiration of self-government is part of the love of freedom."

Also, the aspiration to govern oneself is a measure of human dignity. The demand for civic participation is a healthy thing and the United States' appreciation and recognition of these desires would be a sign of its greatness and strength.

Furthermore, the United States government should regard the concept of a free associated state as one that strikes a balance between "retaining the status quo" and the "independence movement." It is a position of compromise. It comes to terms with both the past and the future. It is a choice that will assure continued economic assistance and increase capital development in Micronesia. Micronesians who oppose this status will have to realize that the world is very different now; the forces of "Western culture" 1 are affecting Micronesia in many ways. Micronesia has become part of the greater world whether Micronesians like it or not. Micronesia cannot continue to live in the past nor dwell in the dreams of impossibilities.

Old myths and new realities must be taken into serious consideration. Realities cannot be brushed aside; our thoughts and discussions must be free of rigid and outdated beliefs. Of all the myths that have troubled the lives of the newly developing nations, the most pervading 
one is that of "extreme nationalism." There has been "Pan-Africanism" in Africa, and other related slogans in the Middle East and Southeast Asia, and here in Micronesia there is a growing "Pan-Micronesianism." 2 It is preeminently a state of mind rather than a state of nature, and it is gradually capturing Micronesia. It is one of the most powerful forces in world politics, and it is also the most dangerous. Pan-Micronesianism is a fanatic cry to overthrow everything non-Micronesian, disregarding all realities and circumstances. It is unfortunate that this extreme form of nationalism has become a force at precisely the time in Micronesian history when technology, knowledge, a common language, and education are beginning to make Micronesia a single unit in the physical sense and interdependent in the political, economic, and cultural senses.

The recommendation of the political status commission for a free associated state of Micronesia is not only meaningful but realistic. It is a choice born out of sad and bitter experiences both of past and present history. Subsistence living has taken so much from Micronesians and given so little in return. Under the new political arrangement, the people of Micronesia will have a chance to live and enjoy the blessings of Western culture and technology while retaining their own respective cultural indentities.

By the way of description, free association involves the concept of an entity. It also requires an agreement or compact. There are two parties to the agreement and each must have existence as an entity. Therefore, Micronesia, while not independent, would be sovereign. The unit or entity Micronesia, as distinguished from her people, would agree to surrender a degree of her independence in order to derive certain benefits for herself. Under free association, the Micronesian people would have those rights and powers they did not delegate to another party (the United States). This concept recognizes the right of the Micronesian people to form a government, and to join with another government voluntarily. Under the United Nations' concept of free association, Micronesia would have recognized international status.

Consequently, an area in free association with an independent nation does exist as an entity. However, the existence is partly dependent on an external power, the degree of which would depend on the terms of the association. Micronesia would retain sovereign power over her internal affairs. Foreign relations and national defense would be handled by both parties in accordance with the agreement. Micronesia would be recognized under international law as a unit or entity. Micronesia could maintain relations with foreign countries in accord- 
ance with the terms of the association. One of the most important features of this status is the right to unilateral termination. This right recognizes that Micronesia is a political entity and gives Micronesia the right to terminate her dependent status in favor of independence. Legally, there are many forms that such a right of termination could take. It would be exercised only under certain conditions, only after a certain period of time, and so forth. The method and conditions of termination would depend on the terms of the association. Further, the terms of association could be altered or amended upon the consent of both parties. ${ }^{3}$

A word about culture is appropriate. Culture is a fighting word in Micronesia. Micronesians take intense pride in their culture and this has been a decisive aspect in their pursuit of a free associated state status. The districts of Micronesia want passionately to preserve their individual cultural identities, but the truth is that they are not at all united on what to do with it.

Today the new Micronesian educated elite and the middle and lower classes are divided into three basic strands: First, there are those who see no prospect of maintaining a local culture and would promore the status quo and eventually settle for a territorial status. Second, there are those who prefer to fight for complete independence regardless of the impossible economic, political, and geographical hurdles such a move would erect. They would throw overboard what has been gained and assimilated, including the English language itself (the only vehicle of unity), and would return to the traditional life of Micronesia. And, finally, there are those who would refuse to do either, at least at this point in time and stage of development in Micronesia. This group insists that it is Micronesia's distinct destiny to be a bridge between Western culture and Micronesian culture, blending the two to some extent but basically building on the Micronesian foundation under the stimulus of Western cultural influences.

The free associated state status comes closest to representing the status desired by this latter group because it provides the only respectable and lucid approach in resolving the future status of Micronesia, given the conditions and circumstances present in Micronesia today. This approach considers not just the people's pride in their culture and their respect for their land system, but it also looks into the problems of education, public health, transportation, and communication, and the economic and political realities of Micronesia. It considers the feelings and aspirations of the older generation as well as the younger generation; it has taken into account the fact that many young 
Micronesians today desire things not Micronesian in nature and character, that there is a whole new class of people whose point of orientation is different from that of earlier generations. This group would rather have a Coca-Cola than a coconut. At the same time, the status commission recognizes that it must also accommodate the aged, the other class of people who would rather have a coconut than a Coca-Cola. Accommodation of the desires of all the Micronesians is the essence of the free associated state status. The leaders in the Congress of Micronesia who advocate this new political status are well aware of the need for maintaining cultural cohesion and identity, because it is from these wellsprings that a society draws its strength. They also recognize the need to provide the technological and economic advantages of Western culture that would be available through an alliance with the United States.

The new status for Micronesia will not be easy to institute. It is hoped that at the conclusion of talks between Washington and the Joint Committee on Future Status of the Congress of Micronesia, certain goals and objectives will be agreed upon. Once an agreement is reached on the basic broad objective, the Congress of Micronesia and the administering authority will have to work out the details as to how the Free Associated State of Micronesia could be established. It is certain, however, that several constitutional procedures would have to be carried our by the people of Micronesia.

The Congress of Micronesia would have to call for a territory-wide constitutional convention, a convention that would represent every sector of Micronesia. The convention would formally adopt a draft constitution for Micronesia. This document would have to be agreed to by the United States Congress and by the people of Micronesia.

After the draft constitution is adopted by the delegates to the convention, the Trust Territory administration and the Congress of Micronesia would jointly call for a territory-wide referendum (plebiscite) in which the people of Micronesia would vote to adopt or reject the draft constitution. Once the constitution is adopted, it would then be presented to the United States Congress for final approval and formal ratification. If this constitution is ratified by the United States Congress, the people of Micronesia and the United States government will have a formal compact, joining the people of Micronesia in a partnership with the United States, the state of Micronesia in free association with the United States.

This formal compact would also grant authority to the United States to present the agreement to the United Nations as a choice made 
freely and independently by the people of Micronesia. This would signify the terminating point for the United Nations Trusteeship agreement.

It is hoped that the state of Micronesia, upon completion of these formal constitutional steps, will call for a state-wide election to elect its own chief executive. These constitutional steps will formalize the changeover from the trust territory government to a free associated state government. Micronesia will continue to use United States currency, the U.S. postal service, and the existing communications and transportation network. This is a general picture of what might happen, details of which will have to be worked out later if and when the new state of Micronesia is created.

It should be noted that the status of free associated state is, by nature and character, a temporary arrangement, which would probably last at least the next twenty years. Its flexibility is probably one of its finest features. It is the opinion of this writer that so long as the United States continues to show interest in both Micronesia and Guam, or until a definite relationship between Micronesia and Guam is settled or clarified, or until Micronesia has opted for complete independence, there can be no real permanent political solution in this part of the western Pacific. As long as the United States maintains its strategic interest in this part of the Pacific and maintains its other commitments in Asia and in the Pacific basin, United States policy will continue to play a leading role in Micronesia, and the Micronesian people will have to understand and become reconciled to these facts.

NOTES

1. The term "Western culture" is used here in its broadest sense, that is, it is not restricted to American tradition alone.

2. Pan-Micronesianism should not be confused with Micronization. The latter is a civil attempt to place more Micronesians in government service in positions of greater responsibility.

3. From Stephen Miller's position -paper on the "Legal Consequences of Free Association," prepared for the Joint Committee on Future Status, 1971, pp. 4-5. 


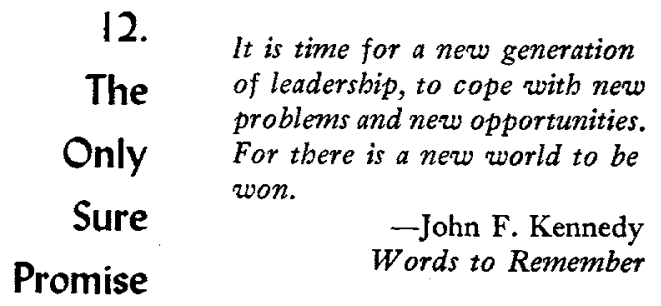

UNDER American stewardship of Micronesia, in 1951 a semi-independent judiciary was created, organized, and staffed by Micronesians, with the exception of the three High Court judges. For all practical purposes the judiciary branch has been functioning quite effectively, taking into consideration the level of education attained by most of its members.

In 1965, another independent branch was created-the legislative branch or the Congress of Micronesia. According to scholars who have observed or worked with it, it is just as good as any other legislative body in the Pacific area. The Congress of Micronesia now has full power and authority on all rightful subjects of legislation.

Only in the executive branch of the government has the United States failed, and stubbornly refused, to relinquish its hold. In the opinion of many people, both Americans and Micronesians, the time has come for the United States to take positive action in this particular aspect of irs administration of Micronesia.

A new Executive Order from Washington allowing Micronesians to elect their own chief executive is overdue. This action will complete the order of business in Micronesia. It will provide an independent execurive branch of government in Micronesia for the first time in its history.

The three branches of government will be run and staffed by Micronesians, with the exception of a few expatriate Americans who will stay on at the request of the new Micronesian government.

The real concern of the Micronesian people all these years has not been so much the external relationship of the United States and Micronesia, but the overly American-dominated and -oriented position 
of the Trust Territory government. Micronesian people can and should be given the chance to run their own internal affairs as they see fit. They should be allowed to create their own policy with respect to their own internal matters.

It is time for the United States to take a realistic stand on this issue. It must abdicate its persistent hold on the last of the three branches of the government-the execurive branch-and allow the Micronesian people to actually learn, by participation, the true art of self-government-learning by doing.

It would be unrealistic for the United States to completely withdraw from Micronesia. But the United States' administrative role in Micronesia could be that of advisor, consultant, and overseer-a secondary role, played in the background and not so much in stage center. This reversal of roles will fulfill the utmost desire of the Micronesians for internal self-government.

The relation and form of a future political arrangement with the United States will ultimately be decided by both the United States and the people of Micronesia. It is up to Washington to recognize this need to complete the rearrangement of Micronesia's government, a need that has already affected the relationship between the two countries.

In the years that have passed between 1946 and 1971 , much has changed in the world and in Micronesia, but much still remains to be done. Micronesia is changing rapidly at a pace that is almost impossible to keep up with. That is why one must pause and take a look at some of the changes that have happened and deliberate some of the problems that have yet to come or be solved.

That there will be change, whether one likes it or not, is the only sure promise that can be made. It is difficult to offer secure and firm commitments about the future, about jobs, about the standard of living, or even about the present way of life. No one can tell another how much money they will earn, no one can even tell another what the political future will be, but change is coming and will come. It is up to the citizens of Micronesia, and especially the young Micronesians, to promote the desired changes.

It is important to consider some of the changes that have taken place recently with respect to the political future of Micronesia. The Micronesian people are divided into three schools of thought. There are those who see no prospect of maintaining the traditional culture and would promote the idea of complete Westernization. There are those who prefer to fight for complete independence regardless of the economic, geographical, and political realities. They would overthrow 
what has been gained and assimilated during the past twenty-odd years and return to traditional Micronesian life.

Between these two extremes, there is a middle course-a synthesis of the two-based on the premise that there are certain wisdoms and values from the past, the traditional culture, that one should try to retain and reconcile with what is acceptable from the present or the Western tradition. Achieving this synthesis is a difficult task and a great responsibility. It calls for courage and moral leadership.

The young generation will be the leaders of the future as well as the heirs to this challenging destiny. They are living in the only period in the long and foreign-dominated history of Micronesia in which Micronesians have been accorded the right to voice their discontentments against an administering power. This privilege was never granted under the Spanish, the Germans, and the Japanese. Even under the traditional system, speaking up against traditional authority was never allowed. In fact it still is prohibited. Indeed, the young generation of Micronesia is fortunate to live at such a period when these basic human rights are recognized and respected. This is to the credit of the United States.

The United States administration in Micronesia desires a closer, if not a permanent, relationship with Micronesia. The present administration has undergone some important changes in attitude. American officials, on Capitol Hill on Saipan, and in Washington, are showing more interest in and greater understanding of the problems of this area. They have promised a more efficient and responsive administration of these islands. There are promises of equal pay for equal work; placement of more Micronesians in positions of greater responsibility; guarantees of compensation and consultation with Micronesians regarding lands. These announced changes and promises are encouraging.

For the past twenty-odd years, actual development and programs have come to and usually stopped at the district centers, the only Micronesia known to the press and the ourside world. Development and progress cannot be allowed to stop at the district centers. Education, medical services, business and commerce, communication and transportation, political development-all must flow into the outer islands and outlying areas of Micronesia. It is difficult to believe how any government, American or Micronesian, can ignore such a sizable portion of Micronesians, remotely situated though they are.

The outer islands people constitute about one-half of the total population in Micronesia today, but what they receive in terms of services and assistance is very small and inadequate. 
The dilemma of poverty faced by these outer islands people is the gap between expectations and reality. Micronesia can no more change these high expectations than it can change its own history. Therefore, the only recourse is to change the opportunities for realizing the expectations, for, as long as there is plenty, poverty is evil. Government belongs wherever evil needs an adversary and there are people in distress who cannot help themselves.

Micronesia has enjoyed the blessings of a great democracy. However, the American stewardship in Micronesia should not be continued on the basis of prevalidation. Stewardship of the trustee cannot be prevalidated. It should be continued on its merits.

The conditions and circumstances of Micronesia's outer islands people are almost the same as they were when Christopher Columbus discovered America; the same as they were when Kaiser Wilhelm decided to colonize these islands; the same as they were when Japan extended its military aggression into these islands; and they have remained the same since 1947, when the United States signed the trusteeship agreement.

As Micronesia continues in its quest for a political future, it must be kept in mind that there are those who will sacrifice everything in the name of "Micronesian dignity." Whatever the choice may be, it must be remembered that there can be no dignity if there is poverty; there can be no dignity of the human life if there is hunger; there can be no dignity of the mind if there is ignorance; there can be no dignity if the body is sick; and there can be no dignity if the soul is without hope. Also, there can be no dignity if these outer islands people have no sense of belonging to their own government simply because that government does not care or will not extend its hand that far.

There are great dangers and difficulties challenging Micronesia. But these are exceptional times; the exceptional challenges which are presented call for exceptional effort. Micronesians must follow the footsteps of their great ancestors who, many years before, roamed these open waters in their sailing canoes and challenged the ourside world to achieve their destiny.

The young Micronesians of the new Micronesia are the apostles of change-they must challenge the unchallengeable; think the unthinkable; and question the unquestionable. They must bring about change, the only sure promise. 


\section{The}

Part 3 Micronesian

Dilemma 
13.

Predicament

of

a

People
If man is deprived of bis freedom be will become either resigned and lose vitality, or furious and aggressive.

-Eric Fromm

The Revolution of Hope

IN THE MOVIE, The King and I, a favorite remark of the king was: "It's a puzzlement." This would not understate Micronesia's problems. The Spanish were not able to solve the "Micronesian puzzle," neither were the Germans, the Japanese, nor the Americans. The Micronesian puzzle remains unsolved. It is a dilemma brought on by elements of the culture, geography, resources, and politics. It is a melting pot of impossibilities. There is hope, however, that perhaps American ingenuity, understanding, and sense of social justice might sooner or later contain the situation and the problems.

Today's Micronesia was born of a history in which the world's big powers struggled to shape their own images. For centuries Micronesia has been a trust of civilization. Even in this day and age of advanced technology and man's conquest over nature, Micronesia is still trying to overcome most of her basic problems. However, Micronesia is now determined to attempt once and for all to shape her own destiny. This is the irony of the predicament of Micronesia. She has reached a point of development where science can help life and environment, and yet, a strong culture and tradition are both not ready to surrender their places.

Micronesia has reached the point where she knows that she cannot have both tradition and modernization at the same time. One has to replace the other. However, a great majority of Micronesians are still very much tradition oriented. It is not at all easy to forget one's past heritage, but the processes of change are not still. They have been in existence since the time early missionaries first Christianized Micronesia and they were given impetus by the arrivals of the German traders, the 
Japanese fishermen, and finally, the United States Marines who landed in the Marshalls in early 1944.

There is a predicament because two equally strong forces are pulling Micronesia in opposing directions. Forces of tradition and modernization are tearing Micronesia apart. Tradition is so strong that there are young Micronesians who are actually advocating a return to the "paradise" of the past. Equally strong are the processes of modernization, so strong in fact that the traditional element has resurfaced to counteract the new forces. There are old traditional chiefs in some of the more conservative sectors of Micronesia who are telling the young people to go to school abroad and find their destiny. There are those who counsel the young people to remain at home. This is a puzzlement.

Another aspect of the Micronesian predicament is the fact that after years of relative isolation by island or island group, Micronesians have finally discovered that there is an entity called Micronesia, an entity created and shaped by outside powers. The phrase "Man in Paradise" is even more confusing, for if he is created from the outside, what is he? Where does he belong? The Micronesian has traditionally thought that his small world was the only one in existence, but to his surprise, he finds that he is not alone, that he has kinship with other districts, and that there is a much bigger world beyond his immediate horizon.

The Micronesian man feels a sense of belonging and oneness with his other fellow Micronesian, yet he has learned, to his disappointment, that he cannot communicate with his newly discovered relatives in his traditional tongue, that he must use a foreign tongue-the English or the Japanese language. This is another of the predicaments that disturbs his sense of balance.

It seems that Micronesia will have to adopt a borrowed language as its national language. Micronesians realize that they are one people and that yet they are not. They want to live in unity, but tradition dictates that there will be six distinct cultures. How does one live, and yet dwell in two different worlds? Can modern science provide the answer? So far, it has not.

With the introduction of the new life, Micronesians have discovered that they have certain basic wants that only the process of modernizarion can bring and help provide. There are new assumptions and rising expectations. Electricity and running water are actually not bad, the Micronesians have discovered. With electricity, many things can be accomplished with less strain. Clean running water is healthy. 
But, again, Micronesia knows that it is difficult to have these things without wealth and a form of government that will encourage the influx of outside capital. Micronesia is poor, her natural resources are few. This is another dilemma. It has no real ready solution.

Education has brought enlightenment to Micronesian thinking. Under the three previous colonial powers, this opportunity was never afforded the Micronesians. The education they received was mostly in technical training. It was only enough for Micronesians to perform certain skills and remain happy and undisturbed. That is why no Micronesians, until now, ever thought of challenging the early establishments or even talking about future political status under the German and the Japanese regimes.

The Americans may someday leave Micronesia, but they will long be remembered, for despite all their shortcomings in governing Micronesia, they made possible a new phenomenon in Micronesia, the "liberation of the mind." Through education, this has become possible. The irony of the situation is that Micronesians are now using what they have learned as a weapon, not to destroy, but to gain equality and social justice, not only against their masters, but also against the archaic, the traditionalist, element.

Another of the real dilemmas of Micronesia, one that is not easily recognized and appreciated, or understood, especially by Americans, is the fact that a great majority of the Micronesian people are being colonized on two fronts-the one favoring modernization and the other the traditional past. In other words, the modern world and the landed traditional chiefs of Micronesia are both operating in Micronesia to gain and obtain control of Micronesia for their own selfish interests. The American military is buying and leasing lands from the people; some chiefs are kicking people off their lands and exchanging those lands for greater wealth. The realities of Micronesian politics are that if you are a commoner and you don't vote in an election for a chief who might be running for public office, you stand a very good chance of losing the rights to your land. You also stand a good chance of losing your creditableness. This is a Micronesian type of colonizing. It is one of the oldest methods of suppressing people, and it is still practiced in many parts of Micronesia. The average Micronesian is caught between two worlds. He must decide which way to go and which of the two is the lesser evil.

The Micronesian quest for a political future is, in many respects, an assertion of the will of the common man to obtain freedom and equality. It is a search for a better and just world. Education has brought about 
this understanding. It has enlightened man's mind, and therefore has given him the courage to challenge the social evils, both from within and without Micronesia.

Micronesia's request for a closer alliance with the United States is derived partly from this social predicament. The United States should realize and appreciate this problem. It is a supplication to end all forms of colonialism within and without Micronesia. Yet, it is compounded by other associated problems. Whatever political status is agreed upon, Micronesia knows that she cannot afford to go it alone. The concept of free association comes closest to a compromise between the two opposing forces.

The answer to these predicaments lies perhaps in the concept of a "curative treatment" approach, rather than a "preventive treatment." Education and understanding on the part of both Americans and Micronesians are needed for the survival of both in Micronesia.

One of the things Senator J. W. Fulbright discussed in Old Myths and New Realities was the attitude of the American people toward United States foreign policy. Americans persisted in believing old myths about other countries, refusing to accept the new realities. In Micronesia, this is equally true; both American and Micronesian attitudes toward the Micronesian situation will have to improve. They must recognize the "reality" of Micronesia as it exists now, and not persist in regarding it as it was during the Japanese time or even five years ago. This is very important if any meaningful discussions and solutions are to be had.

It is indeed a dilemma when a people wish to control their own destiny, but are unable to without involving another party, the United States. Not only is the question of terminating the trusteeship agreement a difficult one to resolve because the form of government superseding it must be decided, but Micronesia's ability to provide a sound economic base for the sustenance of government and life itself is also as difficult to resolve.

In addition, Micronesia's diverse ethnic groups do not share a common political goal. Their unification is therefore a real problem.

Micronesians claim exclusive sovereignty over their lands and their people. They have consistently asked for a greater measure of internal self-government over the past several years, yet the United States has not yielded to persuasion.

Timing may not be on Micronesia's side now, but history is on the side of Micronesia's request for self-government, and it is difficult to imagine that this quest for self-government would not be honored in this 
decade. In the words of English philosopher John Plamenatz, "It is among the imperialist peoples that there is probably the deepest understanding of your predicament and the truest sympathy with your aspirations." " However true this may be, the American military establishment respects no barriers that stand in the way of its never-ending quest for more land acquisition in Micronesia.

On the other hand, Micronesian nationalism is confronted by the dilemma caused by those who would look to the past and the traditional society as unique, nice, and easy and therefore essential to some form of national identity and by those who would cultivate and court modernization, secularism, and the scientific outlook of the more advanced countries. This dilemma is further complicated by a small, bur growing movement toward complete independence.

NOTE

1. John Plamenatz, On Alien Rule and Self-Government (London: Longmans and Green, 1960), p. 208. 


\section{We must dare to tbink "unthink- \\ 14. able" thougbts. We must learn \\ Independence to explore all the options and possibilities that confront us in for Whom? a complex and rapidly changing world. \\ - Senator J. W. Fulbright Old Mytbs and New Realities}

THERE IS NO other issue in Micronesia that is comparable in terms of importance and complexity to the question of the political future of Micronesia. Also, there is no other issue that divides the people of Micronesia more than the question of independence for Micronesia. It is an issue so involved that it may eventually spell the doom of this cluster of islands and its people if it is not dealt with properly, and if emotion and pride take precedence over rationality and wisdom.

Throughout time and history, each people and each generation have had to make such choices. History has summoned each generation of Micronesians to step forth and decide its political destiny. Micronesia is now at that crossroads of decision-making, propelled to that point by the forces of history, and Micronesia must respond to this summons with greatness and dignity-greatness to the extent that those whose responsibility it is to chart the political unknown must not accept independence blindly and foolishly and dignity in that the leaders of Micronesia should reflect on what is possible, rather than on what theoretically ought to be.

Whatever the ultimate choice may be, the leaders of Micronesia would be irresponsible if they chose as their model nations more generously endowed with natural resources than are their lands.

It is without doubt that the only way Micronesia will free herself from American domination and from her own utopian sense of the past is to obtain independence, or at least a large measure of autonomy. Micronesians should be masters in their own country, because so long as Micronesia remains under United States rule, Micronesians will find it 
difficult to rise to full political and social equality with Americans or with any other people. But it does not follow that the sooner Micronesia obtains her independence, the better. If Micronesia obtains her independence before she is capable of efficiently governing herself, to say nothing of achieving social justice and freedom for her people, she may sink into such corruption and squalor that her government will be more greatly despised by her people than if she had continued a little longer under the present system. Where there is corruption and squalor, there is usually oppression as well. Under an independence achieved too soon, the Micronesian people may find themselves ruled by an indifferent and corrupt minority, with nothing to comfort them except the thought that their new oppressors have skins of the same color as their own.

Recent advocates of immediate independence for Micronesia have argued that, among other things, Micronesia is economically weak and that therefore it should return to its past subsistence economy and be independent in that fashion. This is a solution evasive of reality and apologetic in character.

However, before any meaningful discussion on the issue of independence is made, it is best to take a closer look at how Micronesia should approach the whole question of independence.

First, the question is raised, Can Micronesia be independent? It is the kind of question that evokes a "yes" or "no" answer. It is also the kind of question children use when they want something, because the moment an affirmative answer is given, the child is granted the freedom to have what he wants. This type of approach is also very dangerous, however, because it does not require much in the way of rational thought. What is sought in such a question is simply to prove that something is possible, with no regard to the attenuating circumstances.

The second question is, Is Micronesia ready for independence? It is one which is much more difficult to answer because it demands a great deal of analysis and study of certain factors and condirions before an answer can be given. For example, analyses must be made of the level of education, the social conditions, the economic viability, and the fitness and level of political sophistication that the country and its peoples have attained. It has no ready answer. It requires rational thinking.

The third question, Should Micronesia be independent? is the most difficult of the three. It is philosophical in approach and requires sound judgment, judgment not only of facts, but also of values. It requires great courage to answer this particular question. Levels of aspiration 
must be taken into consideration. History, culture, and mores of a people-all are great factors, but none of these can be easily analyzed because there are no tangible facts to be studied.

This is the type of approach that the Micronesian people should consider. The basic question is, What kind of a society do the people of Micronesia want to have, and want to live in? What is the quality of life desired in Micronesia? The responses to those questions create the setting in which the following questions may be raised. Should Micronesia be independent? Is it wise to have it now or next year, or not at all? If modernization is desirable, will an independent Micronesia offer the opportunities conducive to development? These questions are fundamentally difficult. The third question embraces such considerations as feasibility, desirability, possibility and probability, workability, functionality, and the wisdom of independence as a choice.

There is a fallacy in the theory that, by virtue of Micronesia's right of self-determination, Micronesia must, therefore, seek independence. It is argued here that national independence or internal self-government for Micronesia, necessary though it may be to enhance the self-respect of the Micronesian people, is not enough. There must also be efficient government. In the old days, before the dawn of modern civilization and literacy, government could be efficient without being liberal and democratic. It could preserve order and respect for customs and popular beliefs withour being subject to criticism. But relations between governments and the governed are now very different and much more varied and much more active. People expect incomparably more from their governments than they used to; they make enormous demands upon them.

Circumstances differ from place to place, and general situations change from decade to decade. It is therefore hazardous to plan Micronesia's future by looking to Africa and Southeast Asia for precedents Micronesia should follow. Micronesia is indeed one of the unique places of the world. It is difficult to find any ready-made political solution that fits the peculiar situation of Micronesia. It is therefore illogical for Micronesia to try to find her answer in the history of other developing countries. It is sound, however, for Micronesia to judge her own position on the issue of independence in light of her own present circumstances.

There is a strong belief among Micronesians that their right of self-assertion is being delayed and impeded and that, therefore, they must fight to recover this right at all cost. This is noble, but not enough.

While the views and opinions of young Micronesians, and other 
non-Micronesians who are advocating independence, should be listened to with the greatest of care, they are not responsible for the ultimate settlement of the political question. It is the Congress of Micronesia that has been given a mandate by the people to make recommendations on the political status of Micronesia. The Congress will be held for its decision, good or bad, in no uncertain terms by the people of Micronesia.

An indisputable fact about the whole Micronesian quest for independence is that it will not come cheaply at all.

The high costs are recognized by the advocates of independence. Paradoxically, however, they are using it as a justification for opting for independence. Their argument has a negative quality about it. As an example, the independence advocates are saying that Micronesia should become independent by returning to its past where everything will be cheap, simple, and free.

On the other hand, those who favor a slower and more collective approach are saying that Micronesia does not yet possess the educational resources and the capabilities to exist independently and that, therefore, she should not opt for independence at this time.

The former have the attitude of "go for broke," regardless of what the prospects are. The latter want to adopt the attitude of "wait and see," a more cautious approach.

Until it is definitely certain what kind of a society and quality of life-style the people of Micronesia want, it would seem dangerous and presumptuous to conclude that Micronesia should return to its subsistence level of existence.

It has been determined that if Micronesia were to opt for independence within this decade, its government will need no less than $\$ 40$ million annually to provide the social services presently enjoyed and surely to be expected in the furure by the people.

The revolution of rising expectations is increasingly growing. People demand better things. No government, American or Micronesian, can continue to exist or to debate the political issue without considering this reality.

Micronesia is evolving more and more toward a true money economy. Its values are also rapidly changing. The younger generarion is gradually losing touch with the past. Micronesia can neither judge nor decide her future solely on the basis of her past.

How can Micronesia raise $\$ 40$ million on local revenues alone? The estimated tax revenues under the new tax law are insufficient to hold Micronesia together as a political unit. Unless there is a strong 
central government to raise funds, $\$ 40$ million cannot be raised. The unity of Micronesia will gradually disintegrate, and geography will dictate that Micronesians might as well disregard any thinking toward a politically united Micronesia.

With independence comes certain basic necessities. Any sovereign people must also look after their own security. To guard the 3 million square miles within Micronesia's borders and to operate one vessel alone would exhaust funds not less than $\$ 5,000,000$, not including the cost of maintenance. In the area of education and health, the cost of educating the youngsters of Micronesia and providing health and medical services would quadruple that amount.

An independent Micronesia will have to maintain diplomatic relations with other sovereign nations. It may not be necessary, but it is a good way of gaining benefits for Micronesia and the goodwill of other peoples. This, too, will be expensive.

Independence, as many African erstwhile colonies have learned, is expensive. The temptation to establish embassies and legations in the leading capitals of the world, as well as neighboring ones, and missions to the United Nations and its specialized agencies is wellnigh irresistible. These trappings of sovereign independence are costly.'

Assistance from some of the world organizations does not come cheaply either.

There are dues for belonging to the Bank Fund, Labor

Organization, World Health Organization, Food and

Agriculture Organization, International Postal Union, and so forth, and expenses for representation and attendance at meetings. ${ }^{2}$

Micronesian canoes and small boats while very simple and convenient to use in interatoll travel will not do for intradistrict travel or to carry large amounts of cargo. The need to use more advanced systems of transportation cannot be underestimated. This, too, is expensive.

"Many countries feel the need of an airline, international shipping company, or both under their own flags. As a rule with the company comes an annual deficit." "In Micronesia, it cannor be denied that there are political and social justifications for efficient, modern internal travel systems between district centers and remote uneconomic ports, but it will be costly. 
Funds from other countries may be a way to help meet the cost of running Micronesia. It must be remembered, however, that there will always be the proverbial strings attached to outside funding and Micronesia will need to respond to the pull of the strings or she will obtain no assistance.

Aside from monetary considerations, there are also political and social requirements of independence. These cannot be ignored, now or in the furure.

The United Nations has set certain standards and conditions as indicators of a people's readiness for self-government. These are:

First, opinion of the population of the Territory [Micronesia], freely expressed by informed and democratic processes, as to the status or change in status which they desire;

Second, freedom of choosing, on the basis of the right of self-determination of peoples, between several possibilities;

Third, the degree of evidence that the attribute or attributes of sovereignty which are not individually exercised will be collectively exercised by the larger entity;

Fourth, geographical considerations, the extent to which the relations of the nonself-governing territory with the capital of the metropolitan government may be affected by the circumstances arising out of their respective geographical positions, such separation by land, sea or other natural obstacles; and extent to which the interests of boundary states or [districts] may be affected, bearing in mind the general principle of good-neighborliness referred to in Arricle 74 of the United Nations Charter;

Fifth, ethnic and cultural considerations, the extent to which the populations are of different races, language or religious groups or have distinct cultural heritages, interests or aspirations, which distinguish them from the peoples of the country with which they may freely associate themselves;

Sixth, political advancement of the population, to the extent that it may be sufficient to enable them to decide upon the future destiny of the Territory [Micronesia] with due knowledge. ${ }^{4}$ 
It is beyond doubt that proving a country's readiness for national independence or even internal self-government does not come easy. There is a moral obligation to set certain standards for the social good of the people, and additionally, the United Nations does not give out declaration of independence documents very freely. It is the task of the leaders, the Joint Committee on Furure Status, to see that these conditions and requirements are not only attained, but also understood by the people of Micronesia.

Micronesia is unique because of its location, its geography, and its cultural characteristics. For these reasons, no single formula will be easy to utilize. In fact, Micronesia will almost have to create her own formula.

It is evident that independence is the ultimate state of political evolution for any people, including Micronesians. It is not easily conferred on just any group of people. There are certain conditions that must be mer. Micronesia can have independence, if the people are ready and willing to pay the price.

However, in light of the available evidence and the general mood in Micronesia, the option for independence will prove unacceptable. It would, if adopted, be costly in material and human sacrifices, both of which are not necessary at this time. A change in status to independence, while desirable, should be delayed, regardless of whether the United Nations wants to push for an early settlement.

Micronesia has a very unique situation unmatched in the world today. It is strongly urged that the United Nations resolution on the granting of independence to dependent peoples, insofar as it implies application regardless of whether the people are ready for it or not, should be taken with great caution.

Micronesia is the home of the Micronesians. To have the best of possible worlds, only the Micronesians can decide what is good for themselves.

However, under no circumstances should the right to furure independence be compromised. Once the right to choose independence in the future is lost, it will never be regained!

NOTES

1. Charles P. Kindleberger, Power and Money (New York: Basic Books, 1970), p. 36.

2. Ibid.

3. Ibid. 
4. See Jandali Abdulfattah, "United Nations Effort to Set Standards for National Independence," (unpublished doctoral thesis, University of Wisconsin, 1956), pp. 203-204. The subject is treated in much greater detail. 


$\begin{array}{rr}\text { I5. } & \begin{array}{r}\text { Colonialism creates the patrio- } \\ \text { tism of the colonized. } \\ \text {-Jean-Paul Sartre }\end{array} \\ \text { Promise } & \text { The Colonizer and the } \\ \text { and } & \text { Colonized }\end{array}$

WHEN United States invading forces landed in Micronesia during World War II, little thought was given to the fact that the United States was, for all intents and purposes, again writing another chapter of colonialism into its own history. One American writer has said that "few Americans may realize it, but our nation finds itself referred to as a 'colonial power' despite its renunciation of such a policy in 1776." 1 Most Americans will not admit it, but the fact remains that they are colonizing Micronesia. Such a turn of events is unfortunate, for, up to quite recently, Micronesians had never regarded the presence of Americans in Micronesia as being colonialist.

However, when in 1967 Micronesian leaders, through the Congress of Micronesia, started to ask for a greater measure of self-government, they found that certain departments of the United States government were not willing at all to have Micronesians assume grearer responsibility and control over their own affairs, including their lands.

The Micronesian people felt, at the time the first waves of Americans began arriving in Micronesia, that indeed a new and better way of life had finally arrived, and in many respects this has been true.

The loss in material and human destruction suffered by the Micronesians during World War II can never be calculated. Whole islands were destroyed and lost forever, and populations decimated through no fault or cause of their own. Four years of incalculable human suffering came to a stop, and again another power gained control, this time the United States of America. This turn of events brought high hope and great expectation in Micronesia that a new and improved way of life would be coming. 
Twenty-five years later, this same hope and expectation, which the people of Micronesia had anticipated so confidently, is now the basis of serious questioning by the people. There seems to be a big gap between the lofty promises of the Trusteeship Agreement and the performance of the administering authority.

Who is responsible for this situation? Japan? Certainly, to some extent, because she instigated World War II in the Pacific. But can she be made to underwrite Micronesia's economic recovery now that the war is far in the past? It is not certain. What about the Americans? Certainly not directly; they are guilty only of making promises they have not yet fulfilled.

Can the Micronesians be held responsible? In no possible sense can they be considered responsible for their own present predicament, nor of their future if they are not permitted the absolute freedom to decide their own destiny.

The responsibility for Micronesia's present circumstances is that of the United States, who under the Trusteeship Agreement, agreed to certain legal and moral responsibilities. The presence of Americans in Micronesia is not by the right of conquest alone, but also by virtue of the Trusteeship Agreement. The Trusteeship Agreement can be considered the basic constitutional document governing the whole relationship between Micronesia and the United States. True, the people of Micronesia are not a party to the agreement, but as wards of the trustee, they have certain legal rights that are respected under international law.

For the United States, the Trusteeship Agreement is the guiding principle. The document clearly commits the trustee to certain basic responsibilities and moral obligations with respect to the people of Micronesia. These fundamental responsibilities are written in clear and understandable language. They were written into the agreement not by the people of Micronesia, but by the same trustee that has so far failed to carry them out. Without the inclusion of these terms, it is highly doubtful whether the Security Council would have approved the Trusteeship Agreement.

These humanitarian considerations were intended as built-in mechanisms of control as well as ornaments to help balance out the real and only interest of the United States in Micronesia-military. Thus, the United States, in performing its role as a trustee, must also render certain humanistic duties; such civic responsibilities as education, health services, economic development, and so forth, were to be provided in 
exchange for the right to build missile sites and Coast Guard stations, acquire lands, and so on.

After some twenty years of United States assistance, Micronesians look at the "balance sheet" and are appalled to find that it does not balance. The Unired Stares, in fact, has been colonizing Micronesia and willfully neglecting its moral obligations to the people.

Promises have been made since 1946 when an economic survey of the Trust Territory was conducted by the United States Commercial Company. Its recommendations and studies came out in the book Planning Micronesia's Future. Some of the promising recommendations of the study have never been implemented.

Millions of dollars have been spent in study after study since 1946. There have been such studies as the "Nathan Associates Economic Report," the "Solomon Report." Many lesser and more specialized studies have also been made in almost every area of human endeavor in Micronesia.

It is the feeling of many Micronesians that the time has now come for the implementation of programs and projects. The agenda for development in Micronesia is long overdue.

It was because of, and not in spite of, these "unkept promises" that in 1967 the Congress of Micronesia started in motion the decolonization process through its Joint Committee on Future Status, its "status delegation" that went to Washington, and its commission before that.

These three different agents of change were mandated by the Congress of Micronesia to study and recommend to the Congress the best and most realistic course of action with respect to the future political status of Micronesia.

With United States policy, it seems that the end justifies the means, but to Micronesians, the means must justify the end. To the United States the day-to-day governing of Micronesia is of little concern so long as the natives are happy and Micronesia is kept undisturbed. But for Micronesians, being happy and contented are only a small part of the "Micronesian philosophy." Sovereignty, self-government, land ownership, self-determination, all these must be accounted for, and the trustee should not attempt to ignore these vital issues. Indeed, the Micronesian philosophy clearly points to the question, "Who governs whom? Thus far, there has been no satisfactory response.

The United States policy of trying to contain the Micronesian people through the auspicious granting of greater direct appropriations to Micronesia, and the activation of military Civic Action teams, Office of Economic Opportinity programs, and the Peace Corps, has not 
worked because these things are not founded upon the realities of the Micronesian situation. To attempt to offer a pair of sun glasses to a blind man is a useless gesture. What the blind man needs is curative trearment, not adornment.

Five years ago, Micronesians requested that the United States Congress enact an Organic Act for the area. This was a request which stemmed out of respect for the United States. The United States Congress turned a deaf ear to that request. In 1969, and again in 1971, the Micronesians made a similar request, this time for free association status, but again the United States rejected it, countering with an offer of commonwealth status, a disguised form of colonialism. It was already too late; the tide of political events in Micronesia had taken a 180-degree turn, and a new Micronesian philosophy had developed, a philosophy emanating from certain political realities and legal rights.

It is doubtful whether any future United Stares offer that does nor take into consideration the basic question of sovereignty and complete internal self-government for Micronesia will be acceptable.

The unfulfilled promises of the trusteeship agreement have created a gap in U.S.-Micronesian relations. The question here is not whether the Micronesians are anti-American or antidemocracy. The real question concerns principles and humanitarian considerations. What is the role of the trustee? And, how has the trustee performed thus far?

The Trust Territory administration is only an agency of the United States government. Its performance reflects the general attitude and policy of Washington. Policies governing the entire area are made in Washington where the views of the Defense Department and the military establishment are not easily ignored. It is these same people, thousands of miles away, who cannot read or feel the pulse of political events in Micronesia who are dictating the overall policy that governs Micronesia.

Naturally, in such a situation, it would be difficult if not impossible for the agent of the trustee to fulfill its role commendably.

At this late hour, it is doubtful whether any amount of United States dollars can really change the tide of political events in Micronesia. In such an atmosphere, the fulfillment of the responsibilities of the trustee becomes even more difficult, if not impossible.

A new and bold approach to politics in Micronesia is called for. "The American alliance system in. Asia and the Pacific is likely to continue to decay. . . . The true theme of international politics in the area is likely to be that of self-reliance." 2

This is the policy that the United States is likely to pursue in Asia 
and in the Pacific area in this decade. It may not necessarily apply to Micronesia, but it does make Micronesia more valuable and thus vulnerable to United States needs and interests if the U.S. relations with other Pacific and Asian powers continues to deteriorate in the years to come.

The Micronesian overture of an alliance of free association with the United States would be beneficial to both the United States and Micronesia. It is the only political arrangement that can repair the damages already incurred. It will bring greatness to the United States in the eyes of the international community as well as confidence to Micronesians. It will bestow respectability upon the already colonized Micronesians. Finally, it will improve a now bitter relationship. It will be a triumph for the United States-Micronesia partnership.

The trustee can no longer hide herself. She must now show her face and, for once, honestly state her intent and purpose in Micronesia. Since the United States cannot totally pull out of the Pacific and Asia, such an open attitude would kindle understanding and sympathy from the Micronesians.

The recent negotiations between the United States and the Congress of Micronesia's Joint Committee on Future Status and the very fact that Micronesians have taken it upon themselves to chart a course to their future political status are in themselves clear and ample signs of political unrest and dissatisfaction with the past performance of the trustee. It is Micronesia's response to the United States' unscrupulous attempt to engulf Micronesia and to negate her role as trustee of the people of Micronesia.

The position of the Micronesian people at this juncture is that the trusteeship is now due for change, adjustment, or renegotiation. It is only natural that the beneficiary make such a request. The nature of a trust is that the trustee can have no rights against the beneficiary. The conduct of the trustee must be subject to the scrutiny of the world community. The trustee is not a trustee if it is not subject to control.

The United States would be mistaken if she did not take seriously the Micronesian desire for change now. There is as yet no "Yankee Go Home" attitude in the Micronesian approach. It is strictly a friendly reassertion of what are considered basic legal rights. It is the feeling of many that the trustee has forgotten her true role; the Micronesians are simply asking that the trustee give recognition to the Micronesian interest and perform accordingly. The United States will have to recognize that the Micronesian interest in the free association approach is also a recognition of United States strategic interests in the islands, as well as a sympathetic appreciation for democracy and freedom. 
Without any clear direction from Washington, it has been extremely difficult for the keeper of the trustee's interest, the Trust Territory administration, to fulfill its obligations and responsibilities to the Micronesian people in a compassionate manner; yet, as an agency of the United States, it must share some of the blame.

Men of reason must ultimately realize that unless the military aspect of the trustee's role in Micronesia is openly discussed and divorced from the humanitarian considerations, the trustee will have to take the blame for the political problems and the present impasse in negotiations. If the present state of affairs is not changed, it may turn into a political revolution that may spread beyond control. The quest for national unity and free association will disappear.

\section{NOTES}

1. U.S. Rep. Patsy T. Mink, "Micronesia: Our Bungled Trust," Texas International Law Fonum, vol. 6, no. 2 (1971), p. 181.

2. Hedley Bull, "The New Balance of Power in Asia and the Pacific," Foreign Affairs, vol. 49, no. 4 (July 1971), p. 674. 
16.

Unification

and
We bate each otber more than we bate the Americans.

-Dwight Heine Personal Communication

\section{Self-government}

THE QUEST for future political status has come to rest on the recommendation that Micronesia enter into negotiations with the United States in order to create the state of Micronesia in free association with the United States.

Both the Future Political Status Commission and the Political Status Delegation, whose commissions expired in 1969 and 1971 respectively, never seriously took into account the basic problem of Micronesian unification. Unification in Micronesia is a real and potentially dangerous problem that must be studied and appreciated. If Micronesia should fail to cope with this matter properly-and with wisdom-further talks and negotiations may become useless.

Discussions of the problem of unification are in fact discussions about the various ranges and intensities of culture, language, feelings, attitudes, aspirations, and social and political sophistication that exist in Micronesia.

In Micronesia today, there are nine different regional languages spoken. The use of the English language as the only territory-wide medium of communication has divided the people of Micronesia into two groups, the few who govern and the many who are governed; the former use the English language, the latter, who are mainly in their fifties, are generally unable to use that language.

For people over fifty years of age, the Japanese language is used as a territory-wide medium of communication, with varying degrees of success. The fact that the English language is the only national vehicle of political unity in Micronesia, because it is used by the leaders, is little understood nor fully appreciated. It is disturbing that the language that 
is responsible for unifying the people of Micronesia is spoken by but a small proportion of the population.

\section{Nature of The Problem}

Local linguistic loyalties and varied ethnic backgrounds have deep roots in Micronesian history. The six dominant regional cultures are based or centered on language communities. These regional linguistic loyalties represent values more easily intelligible and acceptable to the average Micronesian than any discussion about modernization and international politics. Language creates a people. For example, the Palauan language has created the Palauan people with their unique values, the Yapese language has created the Yapese people. Even the small minority of Carolinians on Saipan have a distinct language and their own values. There is no such thing as an "indigenous Micronesian language" from which can be derived a Micronesian person or a Micronesian national awareness and oneness.

Feelings and attitudes are often by-products of these same linguistic loyalties. What is considered valuable in Palau may have no value at all in Truk or vice versa. The Yapese distrust the Palauans and dislike Saipanese. The Saipanese consider the people in the rest of the districts as inferior and somewhat backward. The people residing in the district centers regard people from the neighboring outer islands as undesirable outsiders, or inferiors who migrate into the district centers to look for jobs and thus create unnecessary problems. Even within a district there are clans and villagers who do not get along with each other, and there are villages or municipalities which are subjugated and ruled by other villages according to their rank or standing within the social structure.

Provincial loyalties are far from dying, and they are responsible for hindering the cause of unity in Micronesia with respect to attitudes toward job and work. It has become most difficult to recruit available and qualified Micronesians for top positions in the administration and elsewhere because those that are qualified find it difficult to work for or under another Micronesian who holds a higher position. This is true in both the district and central governments. There are Micronesians who would prefer working under a non-Micronesian who is not involved in local political issues and generally can arbitrate more objectively on problems and differences.

The fear of domination by a Micronesian of another racial or ethnic group is a major problem in Micronesia. One is a Yapese or a Marshallese first, a Micronesian second. Palauans are believed by some to be aggressive, but if a Trukese or a Yapese must imitate Palauans in 
order to compete as Micronesians, then neither would identify with Micronesia. Micronesians withhold their loyalties on the most basic level.

Much has been made of the fact that the Congress of Micronesia is a "unifying force" in Micronesia. This statement, while it may be true in some respects, needs to be qualified. The Congress of Micronesia is a highly respected institution in Micronesia, but its record shows that it does not fully deserve being called a unifying force.

It can be stated that the Congress has a "united front," projects a false sense of unity, it seems, only because it has a common foe-the presence of the American administering authority. Once that adversary is removed, the united front may fade away, and the inherent feelings of rivalry and regionalism will resurface as they did in the summer of 1967 when a resolution was introduced that would have divided the whole territory into two regions, East and West. This same feeling of regionalism again resurfaced in 1971 , when the procommonwealth and secessionist element in the Marianas boycotted the special session of the Congress in Truk by refusing to send its delegation. Further, the Truk and Marshalls delegations, or at the least some of their members, have openly supported the idea of independence knowing full well the position of the status delegation, whose stand on free association is a matter of record.

Indeed, it can be argued that on the territorial level, the appearance of unity among the indigenous leaders of the six districts is impressive. However, this misleading appearance of unity has, in most instances, been created by the ability of the leaders to adopt and use certain tools and commodities of a non-Micronesian nature and character, such as the use of the English language, the ability to function in the Western culture, the ability to deal with and to manipulate Americans, and the appreciation of the benefits of modern conveniences.

Votes cast in the Congress of Micronesia are generally on the basis of district interest and regionalism with little concern for the common good. Those who vote purely on the merits of an issue are the exception and almost always in the minority.

Demographically speaking, a great majority of the Micronesian people are still living in the remote towns and villages of the outer islands of Micronesia. Close contact with these people is extremely difficult and will probably always be so. Forced resettlement of outer island people is clearly unacceptable.

It is difficult enough for the Marshallese people to make any contact among themselves, but for an outer islander from the Marshalls 
to make any contact with people from the outer islands of Yap, Truk, or Palau would be, indeed, the chance of a lifetime. The people of the outer islands of Micronesia have a very vague concept of what life is like in the district centers, much less in the outside world of today.

Micronesia is fast approaching a change in political status. It is not going to be an easy change. It is the kind of change that calls for the highest level of courage and human understanding. Statesmen are not made overnight; however, in view of all the divisive elements now existing in Micronesia, the Joint Committee on Future Status must set an example of high statesmanship and leadership both among themselves and in their handling of the problems of unification now facing Micronesia. For the political leaders, it is a test of their craft to try to identify the factors and find solutions that will withstand the test of time.

To unify the people of the six districts of Micronesia, who tend to distrust one another and who have had a long history of animosity toward each other, is not an easy undertaking. People do not love one another and live in harmony with each other simply because they are asked to do so. Nevertheless, if our objective is to create a state of Micronesia, then our only recourse is to attempt to impress upon the citizenry the need for unification in Micronesia. This feeling must come from the people themselves. They must "feel unity and federation"; they must be moved to think of themselves as one people with a common self-interest.

History provides some analogies of the problems of trying to unify diverse cultural groups into a single country. In Nigeria, the British organized a great number of tribal groups into a single political entity and gave them a common language-English - and a national legal system, modelled on the British system. But the recent civil war and the tragedy of Biafra has demonstrated the fragile nature of Nigerian unity. The partition of India is another example. The British were blamed for withdrawing too early and leaving the Muslim minority at the mercy of the Hindu majority.

Micronesia may be approaching a similar situation where none of the six districts of Micronesia will tolerate being run or dominated by any other district or by leaders from another district.

Micronesia's contact with three Western colonial powers (Spain, Germany, and the United States) and one Asian colonial power (Japan) has destroyed the traditional life-style almost beyond recall. Western political institutions have taken root in Micronesia and will inevitably become part of life in Micronesia. However, complete Westernization is 
unlikely and perhaps not desirable. Micronesians, even as they change, must change within the framework of their own culture. But as pointed out by Dr. Franck in Why Federations Fail,

It is not enough that units of a potential federation have the same idea of "the Good" but that "the Good" for any one must be consciously subordinate to or compatible with "the Good" for all. This, then, is tantamount to an idealogical commitment not to federation only as means-such as, for example, a means to gain independence or financial stability, to utilize secondary or tertiary factors-but to federation as an $e n d$, as good for its own sake, for the sake of "answering the summons of history." 1

This position must not only be appreciated and understood, it must be felt by and within the leadership of the Joint Committee on Future Status, for unless it is felt, there is little that members of the commirtee can do to generate a feeling of Micronesian identity among the people within their respective districts.

The common means of achieving a semiterritorial unity is through political centralization or a reasonably centralized authority. Excessive centralization, however, may alienate regional groups and other minority ethnic groups from joining together.

It has been pointed out that unless the people of Micronesia "feel united" or "feel federated" there is little that can be done to unite them under one government. They must feel it, and it must be a feeling coming from within. Government cannor legislate fraternity. The blue flag with six white stars has done little, if anything, to inculcate the sense of national patriotism that citizens of many older states of the world passess.

The history of Micronesia itself speaks clearly of the strong isolationism that has possessed the various ethnic groups throughour time and history. After many years of colonization by various powers, the feeling of a shared common interest and fraternity is still very weak, if not grown weaker. It is a problem that may eventually destroy whatever form of government is created or established in Micronesia now or in the immediate future.

Indeed, the fact that unification and centralization are complementary to one another indicates that what little unification or sense of cohesiveness Micronesia may now possess has come and perhaps must come from withour. It must be something non-Yapese, non-Trukese, 
non-Palauan, even non-Micronesian. It must be strong and something new to the total experience and past history of each of the six districts of Micronesia.

Both history and geography have helped to disunite the people of Micronesia, but that is because the process of modernization has played a very litrle part in bringing these islands together until quite recently.

As pointed out by Dr. D. A. Rustow, "The division of labor within a modern society and the sense of common loyalty within a nation rests on a pattern of interdependence. In this pattern, men as individuals remain anonymous and for many purposes interchangeable, but men as members of the same group are known to behave predictably, and can be trusted. To allow for such predictability and interchange, the nation-state must claim exclusive authority over a precisely defined portion of the globe so that its rules can apply indiscriminately to all residents of that country." 2

The great span of ocean in Micronesia should not be used as an excuse for nonunification. Geography has had its share in fragmenting these islands, but its place as a factor in hindering nationalism is minor. Neither mountains, rivers, atolls, nor islands divide or separate nations from each other. It is not mountains, rivers, atolls, or islands that form the boundaries of nations, it is their human inhabitants.

Indeed, the peoples of Micronesia have strong individual attachments to their respective cultures. However, in this advanced age of technology, geography should not be a stumbling block to national unity.

Micronesia, however, is not quite ready, emotionally or otherwise, to depart from its cultural background and history. A confederation of the six districts of Micronesia with a centralized authority may be the logical direction for Micronesia. Such a confederation must be composed of six members who have voluntarily joined together to recognize and protect their common interests within the defined portion of the Pacific Ocean that is Micronesia. Cultural diversity is then a problem, but not necessarily geography, for modern technology can span the geographical distances to unify Micronesia. The economic reality of such a proposal, however, would be expensive and beyond the resource capability of Micronesia. A political alliance or relationship with a bigger power may help alleviate the situation.

It is possible to foresee a government of Micronesia, by Micronesians and for Micronesians, that will be able to cultivate the feeling of unity and oneness among the people of Micronesia. Such a government 
may cause some minor disturbances, but will ensure continuity and guarantee a certain measure of stability in the administration of Micronesia.

The people of Micronesia will not feel a sudden change or drastic reorganization in government and the people may very well experience a new feeling of pride in a government that is now run by their own people. This factor alone may elicit the support of the people of Micronesia in working toward a common goal and a common interest.

Such changes will place all key decision-making positions in the hands of Micronesian people. The legislative branch is already in the hands of Micronesians and so is the judiciary with the exception of the three High Court justices. Major changes in the executive branch are expected to cause a little disturbance but maintenance of the status quo for the most part will ensure a smooth transition of the reins of government from an American-controlled government to a Micronesian-controlled government.

With unification as a major goal, any move toward creating an independent state of Micronesia at this stage will not only cause drastic changes within the governmental structure and in its external relationships, but it will create a turmoil throughout the six districts of Micronesia. It will subject the population to such a radical change that what little cohesiveness Micronesia may now have will be completely destroyed.

A larger confederation may be a logical direction to help unravel the problem of unification in Micronesia. Modern technology may help, but it is expensive. The cost of unifying the six diverse cultures will not come cheap. Whatever option is taken as to the form and structure of the future government in Micronesia, the question of national unification must be seriously considered. The form of government and its relationship to the people and to the outside world is as important as the question of unification. This is one of the few issues facing Micronesia that the Congress of Micronesia cannor ignore. Micronesia cannot have a government without a united people behind it.

At this stage it can be argued that the urgent need is to create a common feeling of unity and sense of identity before significant political changes are achieved.

Geography and isolation should not be used as an excuse for a lack of unification. Micronesia cannot think of itself as a nation living by itself in the middle of the Pacific Ocean. It must want to share and participate in a greater world of commerce and modern technology.

To quote from Renan, "To forget is an essential factor in the 
making of a nation." 3 Perhaps, the only answer for Micronesia is to forget its past history and start anew.

NOTES

1. Thomas M. Franck, ed,, Why Federations Fail (New York: New York University Press, 1968), pp. 173-174.

2. D. A. Rustow, $A$ World of Nations (Washington, D.C.: The Brookings Institution, 1967), pp. 38-39.

3. Ernest Renan, What Is a Nation? in Alfred Zimmern, ed., Modem Political Doctrine (London: Oxford University Press, 1939), p. 190. 


\begin{tabular}{|c|c|}
\hline & The fate of developing nations \\
\hline Th & $\begin{array}{l}\text { depends primarily on the cour- } \\
\text { age and wisdom of their leaders }\end{array}$ \\
\hline Challeng & $\begin{array}{l}\text { and on the responsiveness of } \\
\text { the great peasant millions who }\end{array}$ \\
\hline & \\
\hline eac & $\begin{array}{r}\text {-William McCord } \\
\text { The Springtime of Freedom }\end{array}$ \\
\hline
\end{tabular}

THE PROCESS of decolonization in Micronesia was set in motion in 1967 by action of the Congress of Micronesia. This expressed intention was approved and sanctioned by the administering authority. Since 1967, the Congress of Micronesia has created and empowered three select committees on political status whose primary function has been to study, negotiate, and make recommendations to the Congress of Micronesia regarding any proposed changes in the political or constitutional status of the Trust Territory as a whole.

In the period between 1967 and 1973, there have been many meetings, much travel, debate, and discussion, sometimes within the membership of these commitrees alone and at other times within the entire Congress of Micronesia. There have also been meetings with outside groups and with various agencies of the United States government. In addition, since 1969, six rounds of formal negotiations have taken place between these select committees and authorized representatives of the United States government.

The sixth round of negotiations, and the most recent one, was held at Barbers Point, Oahu, Hawaii in August and September 1972.

A brief review of these talks will reveal that substantial progress and advancement toward the political objectives of the Congress of Micronesia have been achieved. However, closer scrutiny will also reveal that now, instead of one political choice, there are three, each championed by its own political faction within the Congress of Micronesia, a subject to which I will return later in this chapter.

The third round of talks at Hana, while inconclusive, did result in agreements in certain broad areas of vital concern to the Congress of 
Micronesia. Any student or scholar of the Micronesian scene cannot help but appreciate that the United States has come a long way in revising its attitude toward Micronesia. The United States now admits and, to a certain degree, accepts the basic right of the Micronesian people to determine their own political destiny.

More important, perhaps is the fact that these talks have been able to continue and thus have provided a forum in which dialogue between Micronesia and the United States government could be held.

Micronesia in its search for a change in government or a change in political status has also inspired the ambitions that move men in politics. With the creation of the Congress of Micronesia in 1965, the people of Micronesia, through their elected leaders, discovered a new purpose, the development of their islands and societies, toward which they could focus their energies and aspirations. Prior to that, they could only accept without questioning what was given. The Congress of Micronesia, however, created a new channel through which two-way communication could be established between the government and the governed.

There was a sense of purpose, of unity; the people of Micronesia rallied round and behind their representatives in Congress to help find as well as to chart their common destiny. The administering authority began not only to listen, but also to respond. Authority and the control of affairs, which prior to the creation of the Congress of Micronesia were the prerogatives of the administering authority, were suddenly released in greater measure to the Micronesian people. Ethnic, religious, and regional differences that had seemed unimportant so long as an outside administration ruled erupted, and, more often than not, these differences now dominate the loyalties of each districts' peoples as the course along the winding road toward an uncertain political future continues to stunt their previous sense of common purpose and unity.

Today, after eight years of Congress and six rounds of talks, the same people who not too long ago had united behind their Congress are now having great difficulties in moving toward national unity and a common political future.

The challenge raised by the question of Micronesia's future is, more than anything else, a challenge of leadership, a challenge to statesmanship at a trying and decisive phase in Micronesia's political evolution. These are extraordinary times and they demand extraordinary leadership and statesmanship.

Micronesia, whether or not anyone wants to admit it, is being colonized on two opposing fronts: by the forces of modernization and by the forces of Micronesia's own traditional past. The Micronesian 
solidarity which developed at the time of the creation of the Congress of Micronesia is being weakened gradually. Thus, instead of a Micronesian solidarity, there is now Trukese solidarity, Marshallese solidarity, and Saipanese solidarity. National loyalty is being replaced by ethnic and district loyalties.

The pace of rapid modernization and transformation in Micronesia and within the Congress has alienated the leaders from the followers, and thus increased group antagonism within Micronesia. The quest for political status, aggravated by lack of public participation, has enlarged the gap between the Congress of Micronesia and the electorate. The administration's programs of accelerated modernization in economic and social areas may also have increased rather than diminished the scope and intensity of Micronesian political and ethnic conflicts.

With these rapid social changes, and the contention between forces of modernization and traditionalism, political loyalties have also been greatly affected. A great number of people throughout Micronesia today are confused about where their political loyalties lie, a not unexpected predicament since there seems to be no common goal. The Congress of Micronesia is advocating great changes in government and in political status; the administration is pushing for economic and social improvements; and the average Micronesian is caught between these two different, if not opposing, forces. The Micronesian John Q. Citizen is in a dilemma; he is attracted to and receptive to the idea of modernization, and yet is not quite willing to relinquish his past.

For lack of direction, regional loyalty has come to replace territorial loyalty. The people of Saipan want to go their own way, the people of Truk want their own way, the Rotanese want to secede from the Marianas, and it is possible that more districts and groups may soon decide that they too must plan their own future destiny.

I had the privilege a year ago to give a paper at a seminar at the University of Papua New Guinea, the title of which was "Unification and the Coming of Self-Government." Since that time, some of the observations which were made have gradually come to the fore. I had seriously questioned not whether the Micronesians had the capability and maturity of mind to govern themselves, but rather whether they had reached the stage where their diverse and varied district loyalties could bring political unity and a national government which could exert authority and provide a sense of common purpose.

The Congress of Micronesia has somewhat lost its provisional base; perhaps the fact that it is now going to the people, to the districts, to 
hold its regular sessions will resurrect that measure of confidence and pull the people of Micronesia together. Only time will tell.

In the final analysis, it must be this legislative body that ultimately makes recommendations and gives direction in the long and uncertain years ahead as Micronesia strives to define and decide what its political future will be-whether alone or in alliance with another country. The consequences are dire if this august body is unable to provide the kind of leadership that is needed at a time like this, for even greater numbers of ethnic and subdistrict groups may want to go their own ways and determine their own futures.

The second round of talks held in May 1970, on Saipan, between the Political Status Delegation and U.S. representatives revealed profound differences between the two positions. As a result, an impasse was created. At the recently held third round of talks at Hana, the United States came closer than at any previous time to embracing the legal rights and political demands of the Micronesian people, if not in substance and detail, at least in spirit and broad general principles.

However, the talks at Hana also revealed, for the first time, and in an official circle, that the Micronesian delegation has within it profound differences in political opinions and goals. In fact, it would seem that while the United States is becoming more willing to discuss changes, the Micronesian representatives are becoming more divided and are moving further and further away from the position of free association, away from leading the people of Micronesia toward one common destiny.

With all the differences in goals and opinions within the Congress and among members of the Joint Committee on Future Status, it is worth noting that these political factions did not block the joint commitree from pursuing its official position on free association during the discussions at Hana. That course had been set in the mandate that established the committee in January 1971.

In every society affected by social change, new groups arise to participate in politics. Micronesia is no different. It is becoming apparent, however, that Micronesia's Westernized elite no longer can be as self-assured as it used to be. Consolidation of Micronesia's diverse ethnic communities into one nation is further away today than it was six or seven years ago. The challenge of trying to weave the varied social and political fabrics to form the pattern of Micronesia's future will tax the skill and statesmanship not only of the Joint Committee on Furure Status, but of the Congress of Micronesia as well.

There is no assurance that if the present trend continues the 
political objectives of the Micronesian people will be improved. There are increasing signs that people in Micronesia are getting restless, and are confused about Micronesia's political alternatives and goals, and the chances of survival as a single political entity.

There seems at present to be no concerted goal or direction in Micronesia. The administration is pursuing its own goals and objectives according to its own obligations and responsibilities. The Congress of Micronesia is engaged not only in trying to build a nation, but also in pursuing its own priorities and objectives. The district governments and district legislatures go their own ways.

Unless direction arises from some source, national loyalty will continue to deteriorate. The established institutions in Micronesia, such as the Congress, the administration, district governments, the judiciary, churches and schools, do not share the same goal, and are thus unable to provide national direction. Unless they are organized behind a common purpose during this period of crisis in Micronesia, they will not be able to give objective expression to the national will. All these require a national leadership. Both the Congress and the administration are in a position to exercise this kind of statesmanship and leadership.

Perhaps sometime in this decade both the administering authority and the Congress of Micronesia, as representatives of the people, should jointly make some effort to redefine and direct national goals and priorities for the Seventies. Present goals and objectives overlap, and the public is confused. As it is, the interplay of politics between the new hopes and the old ways may eventually yield substantial damage to Micronesia herself.

As a consequence of rapid change and growing uncertainties, people in some areas of Micronesia have found their goals more in tune and in harmony with another's, and with those ideas and concepts which are non-Micronesian in character.

The people of the Marianas, at least a great majority of them, are united and ready to accept the idea of a separate status with the United States with its problems and blessings; they appear to be together in their pursuit of this goal.

A great majority of the people in the Marshalls, Truk, Ponape, Yap, and Palau fall generally under the category of advocates of free association. There are minority factions within these districts, but it can be argued that at least they, too, are willing to adopt a foreign arrangement in which they will be able to share both blessings and problems.

The case of Truk, is an unusual one. Truk, from all appearances, is 
opting for complete independence, free from all foreign domination, including ties with other districts of Micronesia. It is not clear what their idea of independence is-whether it is a return to the past and a subsistence economy or whether it is a proposal to try their hand in the experience of other countries who have achieved modernization and an advanced technology. One cannot overstate the situation, however, for there are those in Truk who may not at all be willing to go the independent way.

Recent political development in the Marshalls is equally unusual. Marshallese political leaders have issued an ultimatum that unless the Congress of Micronesia returns 50 percent of the Marshalls' local tax revenues they will stage their own separate negotiations with the United States.

The official U.S. position at the third round of negotiations at Hana was one directed at and in response to the Micronesian proposal for free association. At no time during the talks at Hana did the U.S. delegation make any attempt to respond to or encourage any discussion in the direction of either independence or commonwealth proposals. And as has been pointed out previously, the official Micronesian position was also directed toward free association.

Internal self-government in Micronesia will come within the next few years, probably sooner than anyone expects. Transition to the status of free association will follow, but political momentum is not always easy to predict with any measure of accuracy. Neither can anyone predict the ultimate interest in the U.S. military nor the economic role of the United States in what will one day be called the former Trust Territory of the Pacific Islands.

It would be in the interest of both the administering authority and Micronesia to push for self-government at the earliest possible time.

To delay internal self-government is to invite separatism and promote division within Micronesia. Self-government is perhaps the only real unifying force left in Micronesia at this late hour. It should have been given six years ago when the Micronesian people were united behind the Congress of Micronesia. 


\section{Preferably that option for uni- lateral termination sbould extend \\ Negotiations: \\ Résumé \\ and \\ Review}

NEGOTIATION could be defined as the art of conferring with another so as to arrive at the settlement of some matter. In the case of Micronesia, the matter to be settled is no less than the very political life and destiny of the one hundred thousand people of Micronesia who have been under the stewardship and control of the United States since 1945, since the conclusion of World War II.

The manner in which a country arrives at or obtains its ultimate political status follows no set formula. Many countries gained their present political status through the process of evolutionary growth, some others by peaceful unilateral declaration of independence, and still others by nothing less than bloody war or revolution. The United States of America gained its independence in this manner.

Micronesia is different. Unlike most other countries in the world, its political future must be negotiated, because, among other things, its ownership is not clearly defined by international law. Micronesians maintain that they own Micronesia, and the United States claims it has mandate over Micronesia by right of treaty and through conquest by war. However, rather than arguing this point, I am interested more in looking at what has happened since 1969 when the first round of negotiations was conducted, and to the future to see just what in the way of a political settlement of the status of Micronesia can be foreseen and perhaps hoped for within this decade.

The first round of negotiations was held in Washington, D.C., in October 1969, at the invitation of the former Secretary of the Interior, Walter J. Hickel. The talks were exploratory in nature and helped lay the foundation for subsequent talks on the political status of the 
Micronesian islands. Indeed, this was the first step toward fulfilling the Congress of Micronesia's mandate on the political status issue.

The Micronesian Political Status Delegation presented a list of eleven points, which provided a basis for reasonable discussions. They were:

1. That the people of Micronesia will draft and adopt their own constitution;

2. That the Micronesians will be assured that there will be no confiscation of their land and no military bases will be established in the islands without full consultation and consent of the Government of Micronesia and fair compensation; that land currently held, controlled or possessed by the United States under lease or other arrangements will be renegotiated;

3. That the United States, subject to certain exemptions, limitations, and conditions, will conduct Micronesia's external affairs and provide protection from outside aggression and consult with Micronesia before entering into international obligations with respect to Micronesia;

4. That Micronesia will agree not to allow any other country to enter into Micronesia for military purposes;

5. That the United States will agree to an early settlement of Micronesia's postwar damage claims;

6. That the United States will remove all barriers to the free movement of Micronesians into the United States;

7. That the United States will also agree to remove all barriers to the free movement of goods from Micronesia into the United States;

8. That the United States will seek full consultation with the Government of Micronesia in matters of shipping, civil aviation and communication;

9. That Micronesians will have access to the. United States Ninth Circuit Court and the United States Supreme Court;

10. That Micronesia will continue to have access to banking facilities in the United States, to the use of United States currency and postal services; and

11. That the Unired States will guarantee financial aid to Micronesia. ${ }^{1}$ 
Although there were no conclusions reached during these preliminary discussions in Washington, the United States delegation agreed in principle with the basic position of the Micronesian delegation, a noticeable exception being the question of land control in Micronesia.

The Micronesian delegation insisted that the people of Micronesia should have unqualified control over their land. The U.S. delegation, on the other hand, presented a formula for the acquisition of land which gave the president of the United States the ultimate power to acquire land in Micronesia.

The second round of negotiations was held on Saipan in May 1970 at the invitation of the Micronesian delegation. The May talks proved to be as detailed and as thorough an exchange of viewpoints as has ever occurred between the two delegations. This second round of talks, however, revealed profound differences between the United States' and Micronesia's positions.

The U.S. delegation rejected the Micronesian offer of free association and proposed instead what it termed "commonwealth" status. This offer was totally rejected by the Micronesian delegation, and this rejection was upheld in the Congress of Micronesia by representatives from all the districts, with the exception of those from the Mariana Islands. The Micronesian Joint Committee on Future Status maintained that the U.S. offer "fell well below the minimum standards of self-government acceptable to the Congress of Micronesia, the people of Micronesia, and the United Nations." 2 This created an impasse between the two negotiating delegations.

The U.S. position at the second round of talks was at odds with the position of the Micronesian Political Status Delegation. The essential nature of free association as defined by the Political Status Delegation was incorporated in the delegation's opening statement. This consisted of the four basic principles and legal rights:

(a) That sovereignty in Micronesia resides in the people of Micronesia and their duly constitured government;

(b) That the people of Micronesia possess the right of self-determination and may therefore choose independence or self-government in free association with any nation or organization of nations;

(c) That the people of Micronesia have the right to adopt their own constitution and to amend, change or revoke any constitution or governmental plan at any time; and 
(d) That free association should be in the form of a revocable compact, terminable unilaterally by either party. ${ }^{3}$

Whatever compromises might be necessary on other points, recognition of these four propositions was an essential and nonnegotiable component of a free association between the United States and Micronesia. These four principles were recognized and adopted subsequently by the Congress of Micronesia in House Joint Resolution 87, in July 1970 .

The Congress of Micronesia convened in Saipan in January 1971 for its Fourth Congress, First Regular Session. By this time, it was clear that more and more factions proposing alternative political statuses were beginning to emerge and that these factions were gaining support.

In the Marianas District, the proposal was for no less than opting for commonwealth status. In May 1971, when the Congress of Micronesia convened in Truk for a special session, another political faction came on the scene, the "Independence Coalition." Its members and advocates consisted mainly of the Truk delegation to the Congress of Micronesia. The Truk Independence Coalition, by taking a stand favoring independent status, became the first district to stand in opposition to the official position of the Congress of Micronesia.

The year 1971 proved to be a decisive year as far as the issue of Micronesia's political status was concerned. President Nixon appointed Dr. Franklin Haydn Williams, with the rank of ambassador, as his personal representarive to the Micronesian status negotiations. At the same time, preliminary discussions took place regarding the crucial third round of negotiations. The Micronesian political status issue had caught the attention of both the State Department and the White House. It was becoming apparent that the handling and responsibility for the negotiations had been removed from the Department of the Interior, and that the White House intended to take a direct hand in the Micronesia status issue.

On October 4 to 12,1971, at Hana, Maui, the third round of negotiations were held. This time, Ambassador Williams headed the U.S. delegation, and on the Micronesian side, Senator Lazarus E. Salii and Representative Ekpap Silk headed a twelve-man delegation as cochairmen.

In Micronesia the political status issue had become critical. The Joint Committee on Future Status was only too happy to accept the invitation to resume further talks, and although the talks at Hana were to be the third in the series thus far, the committee was eager to meet 
the new U.S. negotiating team and what they hoped would be a fresh approach to the political status issue since the impasse of the previous year.

The third round proved to be quite important in that the new negotiating team headed by Ambassador Williams took a different stand. This time the United States accepted the concept of free association as a viable political arrangement for Micronesia providing that the new compact between the United States and Micronesia guaranteed the United States roles in two vital areas-defense and foreign affairs. Aside from these two areas, the Unired States accepted in principle three of the four Micronesian principles and legal rights detailed earlier. The fourth one, the right of unilateral termination, became the only major point of disagreement.

The U.S. delegation insisted that termination of the compact should be by the consent of both parties. On the other hand, the Micronesian delegation maintained that for a small country like Micronesia the right to unilaterally terminate the compact is absolutely essential. The right to unilaterally terminate the compact or any future relationship with the United States, or for that matter with any other country, is more than necessary as a built-in mechanism against any future abusive or reckless use or treatment of the proposed alliance.

The chance that Micronesia may someday revoke the compact or its alliance with the United States is, in my judgment, very remote. Nevertheless, the Congress of Micronesia does not want to take any chances on such an important issue as this.

Clearly, the third round of negotiations at Hana, for all practical purposes, may prove to have been the crucial and significant turning point in the U.S.-Micronesia negotiations. These talks, like any other negotiations between two political entities, have been subjected to close scrutiny and a wide range of interpretations. In essence, the Hana talks laid the foundation for an alliance between the United States and Micronesia. The two parties at the Hana talks have indeed committed one another to a compact of free association, even if the details have yet to be worked out. It would be most difficult for either side to back away from the spirit of Hana, or to introduce new proposals. The U.S. government, the United Nations, and the Micronesian public have all been exposed to those principles agreed upon at Hana. On the Micronesian side, most of the leaders are now almost committed to the terms of the Hana agreements. The Joint Committee and the Congress of Micronesia will almost have to follow through and offer the Micronesian people the compact of free association between the United 
States and Micronesia. The details of the compact then will be the real subject of further negotiations.

In terms of emotional preference, the compact of free association may be a second best for Micronesia. However, the people of Micronesia know only too well that this is the most practical arrangement for them, one that has realistically assessed the unique nature and circumstances of Micronesia and the changing world of this century.

The concept of unilateral termination by either side remains the key issue in U.S.-Micronesia status negotiations. These talks cannot and should not continue too much longer. Micronesia is far behind in her agenda for development and the sooner these talks are concluded, the better. If no basic accord is reached in the near future, Micronesians will lose faith and confidence in both their leaders and in the United States.

Although the Congress of Micronesia can reconsider its stand on the unilateral termination issue, it is best that this stand remain intact in whatever agreement is reached. It is a good reminder to both sides that neither will tolerate abuse of the relationship by the other.

However, Micronesia should not hope to bargain for her future on the loose assumption that she is absolutely strategically vital to U.S. Pacific defense interests. Such an assumption may create serious damage by giving false hope to the Micronesian people, particularly since most of it is based on rentative calculations. What is sound and practical today may not hold true ten or twenty years from now.

Another area of some disagreement has been the extent to which the United States should handle Micronesian defense and foreign affairs interests. Since it is true that Micronesia is undefendable, it is certainly true that Micronesia on her own cannot defend herself against any outside aggressor. If the United States will assure Micronesia that her prior consent would be sought on certain areas of vital local concern, such as fisheries, water rights, and trade, I see no reason why Micronesia cannot let the United States handle her defense and foreign affairs.

The third round at Hana closed with basic agreements on the first three principles and legal rights of the Micronesian people. There was a deadlock on the issue of "unilateral termination." The Micronesian Joint Committee on Future Status came very close to offering a compromise of a five-year period in which either side could invoke unilateral termination. This idea, however, was not offered. There was great commotion within the committee when this idea was advanced for consideration by the members. Since it became clear that the issue was too radical in view of the Joint Committee's mandate from the 
Congress, the issue was dropped from further discussion by the committee.

However, the committee was greatly relieved by the progress of the Hana talks and by the new approach taken by Ambassador Williams. There was a feeling of accomplishment, and a desire to continue with the status negotiations. With this in mind, the Joint Committee issued its invitation to the fourth round of negotiations, to be held in Koror, Palau District. The Koror negotiations were successful in that both delegations reached broad agreement in principle with respect to the issue of "unilateral termination." Thus, the four major demands of the Micronesian people came to a satisfactory end. This action paved the way for the fifth round of negotiations and the actual drafting of the compact.

In the Koror talks, the United States delegation was found to be more willing to accept and more responsive to the four principles and legal rights of the Micronesian people. In fact, these four principles and legal rights were developed into a forum acceptable to both sides, at least, in broad principles. The Koror talks paved the way for the crucial talks held in Washington, D.C., from July 12 to August 1, 1972.

At this point in the four years of status negotiations, the Congress of Micronesia's Joint Committee on Future Status was ready to start thinking about the actual drafting of the compact of free association between Micronesia and the United States. The American delegation to the negotiations was also ready, if not in spirit and moral commitment, at least in its willingness to sit across the negotiating table day in and day out (from which position they continually reminded the Micronesian delegation in so many ways of the importance of the role of the United States in the Pacific Ocean area to keep world peace and security).

In preparation for the Washington talks, the Micronesian delegation arrived one week early; delegation members held a series of meetings among themselves and with Paul Warnke, the Joint Committee's legal consultant in Washington, D.C. With the understanding that the high commissioner was about to call for a special session of the Congress of Micronesia the following month, at the request of the leadership of the Congress, the committee more than ever decided to press for the actual drafting of the compact of free association. This approach was agreed to by Ambassador Williams and the U.S. delegation.

Consequently, two drafting subcommittees representing the two sides were formed. It became the task of these two groups to meet daily 
and then return to the full delegations for discussion and further instructions.

After a month of meetings, a partial draft compact was drawn up, composed of a Preamble, Title I on Internal Affairs; Title Il on Foreign Affairs, and Title III on Defense. Along with these three titles, two auxiliaries, Annexes A and B, were added to Titles II and III. The two annexes were directly concerned with the authority of the Micronesian government in the area of foreign affairs, and with land as it relates to the defense of Micronesia and the United States.

The Micronesian Joint Committee on Future Status and the U.S. delegation reached general accord on the three titles, the preamble, and the two annexes. With this partial draft compact in hand, the Micronesian joint committee returned to Micronesia. A report of the draft compact centering on those parts which the two delegations had agreed to in Washington was presented to Congress in the special session held in Kolonia, Ponape District.

Immediately after the draft compact had been officially presented to Congress and distributed throughout Micronesia, the Joint Committee began to get, very strongly, the feeling of an almost complete rejection of the draft compact. The repercussion within the Congress was sharp and unwavering. The feeling of criticism, however, should be understood. The Joint Commitree had done practically nothing to prepare both the Congress and the people of Micronesia for its report on the fifth round of negotiations. The draft compact was perhaps the most important legal document that had ever been presented to the people of Micronesia for their consideration. Others such as the trusteeship agreement and various secretarial orders are equally important but they were made by outsiders and the people of Micronesia were never consulted on their merits. Thus, the congressional reaction in Ponape toward the draft compact can be viewed as a natural development.

On the whole the sharp criticism and the outbursts by the press and by casual observers were at best shallow and superficial. These self-appointed critics were unaware that the Congress as a whole had met in secret executive session and decided that no action of approval would be forthcoming from the Congress during that session. This strategy had the full backing of the Joint Committee on Future Status.

The fifth round of status negotiations in Washington signaled the end of the discussion of principles and the beginning of discussion of the details of the compact of free associarion. This approach was consistent with the long-held view of the Joint Committee on Future Status that agreement on basic principles must come first. At the Koror talks 
Micronesia's four basic principles and legal rights were met and recognized.

The basic drawback of the partial draft compact was the fact that it was not a completed document. The sections on finance, trade and commerce, and immigration and travel had not yet been negotiated. Time had not allowed the completing of these sections. Thus, the Congress of Micronesia was more than justified in its desire to see the completed compact before giving its final approval. While the Congress in its special session in Ponape was discussing the draft compact, preparations were already in the making for the sixth round of negotiations, to be held at Barbers Point in Honolulu, Hawaii.

The sixth round of talks at Barbers Point failed to produce anything of a substantial nature. The special session in Ponape caused a considerable disturbance with respect to the central topic of the negotiations by authorizing the Joint Committee on Future Status to negotiate independence for Micronesia as an added option.

This new mandate was unacceptable to the United States delegation. Thus, the whole Barbers Point talks centered on procedural questions. The issue of independence completely upset the United States' grand strategy for its Pacific and Asian policy. However, in spite of this failure at Barbers Point, both sides agreed to continue with the current series of negotiations in the hope of arriving at a mutually agreed upon compact of free association.

After the Barbers Point talks, over one-half of the members of the joint committee returned home to face a generally tough election with the issue of political status gaining the attention of most of the people in Micronesia.

The election resulted in the loss of two of the members of the Joint Committee. Cochairman Silk won by the very small margin of eleven votes. All the other members returned to their positions without too much trouble.

After the 1972 election, it became urgent that the seventh round be held if at all possible before the January 1973 session of the Congress. The Micronesian delegation was prepared to resume the talks. However, the U.S. delegation was not because of prior commitments it had made with the Mariana Islands District to start the first series of their separate political status negotiations.

The primary objective of the seventh round of talks is to produce a draft compact of free association to present to the Congress for its consideration. The seventh round of talks has been tentatively scheduled for October 1973. At the time of this writing, the time and place have 
not yet been decided. This seventh round will also consider the remaining issues of the compact of free association, namely, finance, unilateral termination, and U.S. land requirements in the District of Palau. Palau's traditional leaders have gone on record to oppose the use of their islands for military purposes. Their appeal has been presented to the Joint Commitree on Future Status and the committee has no choice but to follow that mandate. Primarily, the request of the Palauan traditional leaders is that all public lands in Palau now held in trust by the Trust Territory government be returned to their original owners. U.S. negotiators would then negotiate directly with the landowners. The leaders have said that unless this request is honored, they would not allow U.S. military to acquire land in Palau.

\section{NoTES}

1. Report of the Political Status Delegation, Saipan, Mariana Islands, July 1970, pp. 2-3.

2. Ibid., p. 7.

3. Ibid., p. 11. 
19.

Freedom

from

Within

and
We know tbrough painful experience that freedom is never voluntarily given by the oppressor; it must be demanded by the oppressed.

- Martin Luther King, Jr. Why We Can't Wait

\section{Without}

IN THE LAST two decades, the world witnessed the demise of colonialism in Asia and Africa. Decolonization of Oceania began much later, but the people of the Micronesian islands in the Western Pacific feel no less strongly that they, too, must remove the last vestiges of colonialism in Micronesia, and join in the almost universal recognition that all peoples have the right to control their own destinies.

However, the process of decolonization in Micronesia, unlike that which has occurred in most of the countries of the Third World, is a revolution to end colonialism both from within and from without. Micronesia's quest for freedom, as with its other social, economic, and political aspects, is confronted with a dilemma. It is the contention of this writer that Micronesia, in its struggle to free itself from the domination of American colonialism, must also attempt to free itself from a persisting traditional past-a past that has little to contribute in this day and age except, perhaps, a tradition of submission and a desire for an isolated existence.

Micronesia's own past civilization has taken much from the Micronesian in terms of "sweat, toil, and tears," and given very little in return. Micronesia has suffered a great deal at the hand of her own past, a past that has been not only brutal and miserly in its rewards, but one that has tolerated social injustice and has shown little concern for the future welfare of its own youth and its people. Micronesia's own traditional past, throughout the years, disregarded Micronesia's own social problems, and was not able to provide the necessary conditions and circumstances in which the problems of ignorance, hunger, health, and poverty could be improved, contained, or dealt with. 
On the other hand, modern civilization, especially twentieth-century Americanism, although it has provided many material rewards, and rewards in terms of education and improved health services, has also, during the past twenty-odd years, shrewdly attempted to contain and to swallow Micronesia in a grand design for complete ownership of Micronesia.

This is the dilemma which the average middle-class Micronesian has found he has to face. Micronesians of this age are faced with a dilemma formed by their own traditional colonialism and the modern neocolonialism of big powers.

The colonial heritage of four outside major powers has left an indelible scar on Micronesia. Between the Treaty of Tordesillas and the present Trusteeship Agreement, over four hundred years have elapsed. For over two hundred of these years Micronesia was subjected to the rule of four successive colonial powers, three from the West (Spain, Germany, and the United States), and one from the East (Japan).

It is, however, not the purpose of this book to examine in depth the penetration of Micronesia by each of these powers, except to observe some of the obvious results of their individual regimes. The Spanish laid the earliest foundations of Christianity (Catholicism) in Micronesia, and this paved the way for the later spread of the other branches of Christianity, especially Protestantism. In the Mariana Islands, the impact of Spanish life and culture was so great that it almost wiped out the original culture of the Chamorro people. In the other districts the Spanish influence was not longlasting, except in its religious impact.

The Germans, on the other hand, were not interested in converting the natives to any particular way of life or to any new religion. Their main interest centered around trade and commercialism, mainly for the benefit of the German government. The copra trade was greatly improved and commercialized during the German administration. The Germans taught the natives business techniques so that the natives could help them in the copra trade.

The Japanese were not much different from the Germans. The Germans acted strictly in their own interests. The Japanese did too and in addition they were more sure of themselves in that they knew what their goals in Micronesia were. They thought they were going to be in Micronesia forever. Consequently, they made every attempt to integrate the Micronesian people and culture into the Japanese system. The influence of the Japanese on Micronesia was by far the greatest, with the exception of the Americans.

Up to the end of the Second World War, Micronesia had been 
under the rule of foreign powers almost constantly since it was first discovered by the Spanish in the early sixteenth century. The Spanish period lasted for almost two hundred years. The German period was brief (1899-1914), ${ }^{1}$ as was the Japanese (1914-1944), a total of some fifty years. The Americans have administered Micronesia for almost thirty years (1944-1973).

The colonial experience under the Spanish, Germans, and the Japanese had softened Micronesia in such a way that American penetration, beginning in 1944, was relatively easy and smooth. Micronesian receptivity to the process of modernization developed and accelerated much later (under the American regime), mainly as a result of the German and. Japanese governments' subdivision of Micronesia into various administrative districts, and an influx of material goods and an accelerated educational system, both of which are relatively new. Their impact cannot be underestimated.

These new schemes initiated by the Americans gave birth to new agents of change which have had a great impact on Micronesia.

The development of district centers throughout Micronesia has brought about urbanization. People from the outer islands migrated to the district centers in the hope of finding new job opportunities and a new way of life. With a new job and a new life centered on a money economy, a once-religious people began turning more and more to secularism. Secularism became a new way of life, outside of the usual religious life.

With greater material wealth and a money economy, people came to realize that they could increase their wealth through commercialism. Businesses were developed and organized. Catalogs from Sears and Roebuck and Montgomery Ward became the bibles for this new group of businessmen.

Education in Micronesia and abroad opened the minds of Micronesian yourh to new knowledge. Nothing in the way of traditionalism was left unquestioned when those who went abroad came back. This newly educated class brought new concepts to Micronesia.

These four agents of change gave rise to the present revolution of rising political expectation within Micronesia.

From 1960 on, Micronesia experienced a great reevaluation in its social, economic, and political attitudes. Those Micronesians who had gone overseas to school returned and were critical of the administering authority, saying that it had become static, that it responded to change too slowly. Swiftly, this newly educated elite pushed for reforms. They demanded that a territorial legislative body be created, and their 
demands resulted in the establishment of the Congress of Micronesia. Furthermore, they demanded that Micronesians be appointed to higher positions in the government; thus the administration began to appoint Micronesians to top-level posts in the district and territorial governments. There were even requests that Micronesia be annexed as a territory of the Unired States. Those more acquainted with bureaucracy and its conduct were demanding "equal pay for equal work." As of 1972, there were two major pay scales in Micronesia, one for U.S. employees, and one for Micronesians. The Micronesian pay scale had four different classifications of pay levels. Salary compensation has invoked bitter feelings between Micronesians and Americans, perhaps, more so than any other area. It is here that the American feeling toward the Micronesians has really shown its true color.

In the early stages of the American administration of Micronesia, very few Micronesians were qualified, even as clerks, to work for the administration, much less to assume positions of importance and responsibility. Consequently, Micronesians were told to go to school overseas, and they were promised that upon their return, they would be promoted to high positions within the administration. Returning Micronesians found that they had to go through additional "on-the-job training" before they could be advanced to the higher positions that paid higher salaries. There seemed to be no end in sight to what Micronesians had first to do before they were thought to be qualified for any high-level job or pay in the administration. Up to the time of the implementation of the new classification system in Micronesia, classification of positions was more in accordance with racial status than anything else. Even if a Micronesian were accorded the rank of a district administrator, the highest post in the district government, his salary might still be below that of his secretary, if his secretary happened to be an American.

The fact must be realized that for some twenty years of American stewardship of Micronesia, a small band of American bureaucrats has dominated the administration and thus has perpetuated its own interest-a group that is qualified to be categorized as an example of the "ugly American." This group has hurt the American image in a place that is very sensitive because of its international status. Washington paid very little attention to the situation in Micronesia until 1971, when the "Micronesian situation" could no longer be contained. The Department of State and the White House were finally brought into the picture with the appointment of Dr. Franklin Haydn Williams as President Nixon's personal representative to the Micronesian status negotiations. 
It was in 1967 that the Congress had taken steps to decolonize Micronesia, so by 1971 there was no turning from the impasse to the former way of life. The U.N. gospel of "self-determination" had taken root with the Micronesian leadership elite. Their only recourse was the court of world opinion and the United Nations.

The strategy for the "rendezvous with destiny" was already in the legislative mill. The newly established Congress of Micronesia adopted Senate Joint Resolution 25 which ultimately created the first Future Political Status Commission whose mandate, among other things, was "to insure that [the Micronesians] are fully cognizant of the issues involved and the range of alternatives open to them with respect to their future political status." 2 The impact of this joint resolution was phenomenal. Micronesia has never been the same, and it will never return to what it had been in the past.

The feeling in Congress at the time was that the task of deciding the political future of Micronesia was not the sole responsibility of the administering authority. The Micronesian people had a lor to say about what their ultimate destiny would be.

After a summer of traveling and study (1969), the political status commission was ready to submit its report and recommendations to the Congress of Micronesia. Taking into consideration the United States' strategic interest in the Pacific and particularly in Micronesia and also the realities of Micronesia's social, political, and economic resources and capability, the commission recommended that Micronesia seek a status of free association with the United States. This recommendation was subsequently adopted by the Congress of Micronesia.

It is not enough simply to establish broad principles to guide Micronesia's political future. There must be some concrete plans and blueprints ready should Micronesia enter into a compact with the United States. The simple questions are: What comes after trusteeship? How will the new government operate? In what fashion or what model? What will be its source of revenue? In short, what would be the most functional system of government for Micronesia? These questions, and many more, have not escaped the minds and imaginations of the Micronesian leadership.

Under the concept of free association, Micronesia may continue with its present system of presidential government with three separate but equal branches of government. Such a system, while it would be easier than others to implement because the people of Micronesia are well acquainted with it, also has its disadvantages. For one, it is expensive, and I doubt whether Micronesia can afford it. Furthermore, it 
does not solve the problems of regionalism and animosity within and among the districts. However, $I$ think it would be in the interests of continuity and smooth transition for Micronesia to remain with this system for several years more; new concepts and systems can be worked out during that period.

There is also merit in the concept of an "execurive council" for the period of transition and actual change in status. The executive council would constitute a corporate head of state whose members would represent both the executive and legislative branches of the government. Such an arrangement would resolve the problem of regionalism, since the executive council would undoubtedly consist of representatives from the six districts of Micronesia.

The whole process of decolonization that has occurred in Micronesia since 1965 has made many Micronesians more consciously aware of the role Micronesia must play as a member of the community of small islands and nations in the Pacific Ocean. Micronesia cannot hope to isolate itself from its neighboring Pacific islands; it also cannot stop the greater world from moving into Micronesia. The world of the twentieth century has engulfed not only Micronesia, but also the other countries and islands of the Pacific Ocean.

Micronesia, however, can control, to a certain extent, the life-style or the quality of its own society. But, it will not be able to hold itself from those changes that will inevitably surface from within its own society. The fact has been made painfully clear in recent times that despite strong cultural resistance against the forces of modern science and technology, Micronesia within the past twenty years has experienced great changes. These changes have come and are still coming. Their impact cannot be overlooked. The process of modernization has almost revolutionized the urban centers of Micronesia and these changes are slowly but gradually finding their way into the remote communities of the outer islands. This is the only sure promise that anyone can make about Micronesia or in Micronesia: that change is inevitable.

During the past ten years in which Micronesians have been seeking a better world for themselves, a world that is in tune and compatible with their own cultures and traditions, they have come to discover one painful aspect of themselves - the dilemma that they are not one people, that they are not of one mind, that there are deep-rooted feelings of animosity and prejudice deep in the heart of their homeland.

The more than two thousand islands and three million square miles of saltwater in the western Pacific that is Micronesia is a creature shaped by global politics, by the machinations of Western powers in seeking to 
"reshape the world in their own image." Prior to their discovery by the Spanish, Micronesians had always been an isolated people, isolated even from each other, each group living in its own small world. As an entity carved out of the Pacific Ocean by Westerners, unity and harmony have not come easily to these people, who have pride in each of their respective cultures.

Nationalism in Micronesia stems from within, but it was created and motivated by the forces of colonialism. Thus, while nationalism is a bitter enemy of the administering authority, it is also its product. With the rise of nationalism in Micronesia, we have also seen the emergence of a diversity of political groups, each aspiring to gain a foothold in the arena of national politics.

Agitation for independence formally started in 1971, with its base in Truk District. It is too early to make any valid assessment of its growth or its strength. It is nevertheless a force to be reckoned with, if not now, in the years to come, for to Micronesia with her chronic problems of poverty, disease, and illiteracy, and to Micronesia with her strong orientation to her past and to its heritage, independence does make sense. By becoming independent Micronesia will be able to protect her own self-interests. However, in the context of individual righrs and liberty and the reality that the new generation in Micronesia is oriented to modernization, not to what it considers an archaic past, one must ask the question: an independent Micronesia for whom? Who will benefit most if Micronesia should become independent now? Obviously, it will be the traditionalists, the landed paramount chiefs. Independence is considered by them to mean a Micronesia as it was in the past.

If Micronesia is to have her independence modelled after those countries which have recently acquired independence, she will almost have to consider such an option. Such an option, though noble in character, will create more disadvantages than advantages. Micronesia's balance sheet of progress in an independent status will most likely be in the red, at least in the context of fulfilling twentieth-century expectations.

The course of Micronesian aspiration toward self-government and/or independence has been marked by difficult problems. Some of these problems have arisen from within Micronesia, and some have been imposed from without. Since promises of development in Micronesia have not always been fulfilled, there should be no reason to blame or belittle Micronesians for their quest for freedom. But, if Micronesians 
are unable to work together for their own common good, then they themselves must find the solution.

It is here in the area of Micronesia's lack of natural resources that perhaps some degree of cooperation between Micronesia and the administering authority can be worked out. As a matter of fact, the proposed free association embraces this very possibility. The various select committees on political status, created by the Congress of Micronesia, have recognized "the wide spectrum of interests which have linked the United States and Micronesia in a strategic trusteeship. That very term-strategic trusteeship-implies a variety of interests, ranging from pragmatic military considerations to idealistic stewardship, which have mingled and sometimes clashed in the history of the administering authority. Yet, despite past difficulty with the United States' purposes and cross-purposes here, the first status commission acknowledged the validity of these interests and felt that they could be accommodated on reasonable terms in a self-governing Micronesia. Therefore, the status commission's request for free association with the United States was based, at least in part, on a recognition of American interest-or interests-in Micronesia." 3

It is difficult to see how the administering authority could fail to see the spirit of accommodation and generosity exhibited by the Micronesian people, despite all the enormous problems that have presented a dilemma for them. Micronesia's weakness in natural resources and her internal cultural problems have placed Micronesia in a predicament that suggests no easy solution. However, the lack of cooperation and contact between the administration and the Congress of Micronesia adversely affects the working relationship at the policymaking level, and, hence, a solution to the predicament.

Indeed, the challenge to the political future of Micronesia is a challenge of leadership, both in the administration and the Congress of Micronesia. The average Micronesian citizen is lost and confused for lack of direction.

In a presidential system of government, such as Micronesia has, it is not unnatural to have differences of opinion between two equal branches of the government. However, when there is confusion as to the role and authority of the branches, then there is a crisis of leadership in which public interest and loyalty become the victims.

Micronesia's quest for freedom from the dominant force of American colonialism came about as a result of many contributing factors, most of them created by America herself. Lack of foresight and 
unimaginative policies have caused more harm to America's reputation than anything else. Prior to the creation of the Congress of Micronesia, the administration had consistently refused to allow Micronesian participation in the overall planning for Micronesia.

If it is the role of the trustee to see that the beneficiary's best interest is served, then it would seem only right and reasonable that the trustee listen to what the beneficiary has to offer. Many people in Micronesia and most recently the Congress of Micronesia have come to resent the fact that many important decisions are being made in Washington and elsewhere in the administration without the advice and input of the Micronesian people. Many experts thousands of miles away were artempting to identify the needs and priorities of the Micronesian people. In many instances a solution was to be had in Micronesia, but Washington had ready-made solutions for almost every conceivable ill and problem of Micronesia.

Micronesia wants to be free of domination from forces both within herself and from outside. Micronesia is faced with a dilemma of a people brought together by the forces of colonialism and a struggle for both political and economic freedom. Micronesia, however, cannot hope to have the kind of political freedom she wants unless she determines what she wants. In respect to economic development, the United States has not been lacking in goodwill. Some of the blame must be placed on the administering authority, but a great deal of it must be directed at the Micronesians themselves. Land is essential to any kind of economic development, and if Micronesia wants economic development, she must realize that she cannot continue to preserve her land-tenure systems under the excuse of trying to preserve her culture. Political freedom in Micronesia is dependent upon economic considerations. Micronesia will secure her political freedom from the administering authority, but can she secure her economic freedom from a feudalistic land system and from a tradition that many want to preserve?

Today, after many centuries of domination by forces from the outside, as well as from within, one can only speculate as to whether Micronesia can afford a new freedom from without, particularly if she is unable to secure a similar freedom from within.

I believe that Micronesia is in too much of a hurry, and that the mere attainment of political freedom for Micronesia will not necessarily make Micronesia a free society. Freedom cannot be acquired so cheaply, nor so quickly. Neither can it be a product of a series of negotiations.

Freedom is possible for Micronesia through evolutionary growth 
and through the development of a new society that respects individual rights, freedom, dissent, and equality.

The new society under any new political arrangement must be in good working order. It must show a strong sense of unity. Its government and economy must function smoothly. This means that there must be a wide diffusion of technical skills, and political and social skills as well. In this respect I accept what Mr. Hoffer has suggested, that "a free society is also a skilled society." 4

Many people in contemporary Micronesia are more interested in the struggle for freedom than in the actuality of a free society, the means rather than the end. The fact is that if Micronesia is incapable of making social and political reforms from within herself, she cannot expect to enjoy true freedom. There is no sense in exchanging an outside form of oppression for one from within Micronesia.

\section{NOTES}

1. The Germans engaged in trading in Micronesia as early as 1885. Legally, however, Germany purchased the islands from Spain in 1899.

2. See chapter 8 for greater detail.

3. Future Political Status Commission's Report, Congress of Micronesia, Saipan, Mariana Islands, July 1969, pp. 18-19.

4. Eric Hoffer, The Ordeal of Change (New York: Harper and Row, 1963), p. 79. 


\section{For bow long could be fail to Epilogue: see the misery of the colonized An Overview and the relation of that misery to bis own comfort? -Albert Memmi The Colonizer and the Colonized}

THE AMERICAN defense role in the Far East, Southeast Asia, and the entire Pacific Ocean area has been reduced and lessened considerably in recent years.

The Japanese have gotten Okinawa back, the Vietnam war is over for Americans, the Leftists in Japan want all U.S. troops to leave that country and the U.S.-Japanese Security Pact terminated. United States troop strength in Taiwan and Korea has been cut, and many people in the Philippines want the United States to move out or pay a higher rent on military-use lands. Overall, we are seeing the gradual reduction and weakening of American involvement in this part of the globe. This trend is consistent with the Nixon Doctrine, which calls for reduction in American troops in the Pacific, Far East, and Southeast Asia.

For those who are not familiar with the geographical location of the Micronesian islands, the recent rounds of status negotiations concerning the political future of these islands may seem insignificant and perhaps unimportant. However, these talks are directly related to U.S. involvement in Pacific and Asian affairs and a closer look reveals that the "balance of power" theory has much to do with the U.S. position.

The political status talks represent a really serious attempt by U.S. planners to reach an accord with the Micronesian people about the political future of their islands. But U.S. policymakers are especially concerned with the future role of the U.S. military in these islands, and with U.S. policy toward the Pacific Ocean area. Thus, while U.S. policymakers are trying to paint an overall picture of the withdrawal of the U.S. military from the Pacific, the Far East, and Southeast Asia, the 
facts of these recent negotiations do not give that impression at all. On paper this impression may be some source of satisfaction to the United Nations and the world community, but the fact remains that the United States wants to remain permanently in Micronesia, wants to use Micronesia as a security buffer, and wants to maintain its influence in the Pacific and Asia.

While President Nixon was repairing twenty years of strained diplomatic relations with the People's Republic of China, preparations had already been made for his personal representative to come to Micronesia once again to negotiate not so much the political destiny of some 107,000 Micronesian people, but the furure role of Micronesia as a military base for the United States. This is the reasoning behind U.S. actions at the negotiating table.

For the United States, the success of these negotiations is absolutely necessary. These islands, together with neighboring Guam, represent the last of the U.S. defense strongholds in the western Pacific.

From all practical considerations, the fourth round of talks held at Koror, Palau District, seemed a real victory for the Micronesian people. The United States had embraced, at least in substance, all of the four principles and legal rights espoused and adopted by the Congress of Micronesia and articulated by the Joint Committee on Future Status. But closer scrutiny reveals that the real price Micronesians will have to pay to be freely associated with the United States is having to continue to host the U.S. military under a status of forces agreement, now under negotiation. This is exactly the same arrangement and price the Japanese paid under the terms of the peace treaty they signed in San Francisco in 1951. What is not commonly known about the Japanese peace treaty is that although the United States signed the peace treaty and thus granted Japan her independence, she at the same time, under John Foster Dulles, worked out a deal known as the "Yoshida-Dulles formula," which provided for a security pact with the Japanese people.

Thus, Dulles accomplished then what he needed for his Pacific and Asian policy, and it seems that Ambassador Williams is moving to do the same in Micronesia.

It is difficult to understand and appreciate fully the real drama of these last six rounds of negotiations without any background information on the events leading up to the first round of talks and the role which the Congress of Micronesia has played in these negotiations during the last four years.

The real turning point in the Micronesian struggle for freedom and 
self-government came with the creation of the Congress of Micronesia. The Congress has been the real agent of social, economic, and political change in Micronesia.

Before the 1960s, United States policy in the islands had been one based on a "zoo theory," a "holding operation." Fifteen years ago, the budget for the islands was about $\$ 7$ million annually. The official justification for so small an appropriation was that the United States did not want to create permanent wards by establishing a budget which Micronesia could never hope to meet from her own resources. But a change in philosophy occurred when the Vietnam war began to escalate and pressure began mounting for the reversion of Okinawa to Japan. Within a few years, the budget rose to about $\$ 40$ million, and today it stands at $\$ 60$ million, though Micronesia's economic potential has remained unchanged. Our second largest export still remains scrap metal from World War II, and our largest export is copra, the biggest loser in world markets today. For a political entity that encompasses some 1,300 miles of ocean from north to south, and more than twice that distance from east to west - over three million square miles of ocean-it is difficult to understand why the total export of fish last year amounted to only $\$ 900,000$. Micronesia's only real source of revenue, unfortunately, is grants from the administering authority.

Sometime in the early 1960s, when Washington was forced to bring the islands out of the "zoo" and into the orbit of the twentieth century, education was placed in the forefront of deliberately fostered cultural changes. This was done on the premise that trained manpower was essential for increased economic activity and an informed citizenry necessary for self-government. But whatever measure of success or failure we assign to U.S. activities during the trusteeship, one element stands above the rest - the establishment of democratic institutions.

Ironically, this, the greatest achievement in Micronesia of the richest nation on earth, cost practically nothing.

In 1965, the administering authority finally allowed a territorywide legislative body for Micronesia. In that year, Executive Order 2882 , as amended, was issued, creating the Congress of Micronesia. To Washington, it was just another legislative assembly similar to those created in other U.S. territories. Little did Washington realize then that the whole U.S. defense posture in the Pacific would be altered in such a way that the Congress of Micronesia would become a leading actor in the whole drama.

In 1967, the Congress started the movement that would lead to the alteration and redefinition of Micronesia's governmental structure and 
to the determination of her political future. Yet, Washington remained unconvinced of the seriousness of the Micronesian quest for self-government.

In 1970, Washington finally began to realize how serious the Congress of Micronesia had been. In 1969, the Congress established the first political status commission to study the political arrangements of other islands and countries of the Pacific area. Upon the return of the commission from their study trip, the Department of the Interior took the first step by inviting the status delegation to Washington to begin discussions on the political future of Micronesia.

The Department of the Interior represented the U.S. government at the first two rounds, and completely failed. It failed because there was no genuine effort to try to understand Micronesia and Micronesians in their struggle to gain a new and better status for themselves. The Interior Department had no new ideas to offer except annexation or commonwealth-both of which were turned down outright by the Congress of Micronesia.

In 1971, the political situation in Micronesia reached a point of explosion. The Interior Department seemed incapable of exercising the necessary amounts of imagination and foresight. The White House then moved in and took over completely the Micronesian political status negotiations.

At the third round of talks at Hana, Maui, in the Hawaiian islands, the new U.S. delegation conceded three major issues: eminent domain, control of law, and the right of self-determination. Moreover, for the first time, the United States spelled out its actual defense needs and requirements in Micronesia. Unilateral termination became the only point remaining unresolved.

For Micronesia this was a very refreshing approach. As a result of these major concessions made by the United States government, the Micronesian commitment to the idea of free association became stronger. The Joint Committee on Future Status issued the invitation for the fourth round of status talks to be held in Micronesia.

In Koror, the U.S. delegation continued to move toward agreement on the Micronesian proposal for a state in free association with the United States by accepting in principle unilateral termination. This action satisfactorily met the four major demands of the Micronesian people, demands which must constitute the basis of any relationship of free association with the United States.

At Koror, a new element was introduced into the status talks: the issue of transition. The U.S. position, agreed to by the Micronesian 
delegation, was that any meaningful approach to the issue of Micronesia's freedom and self-government necessarily implies a period in which actual transition of administration will take place.

Under the broad agreements reached at Koror, Micronesia would become, after the change of trusteeship status, a fully self-governing state in a relationship of free association with the United States. All internal matters would be under the control of the Micronesian people and their elected leaders. The United States government would be responsible for Micronesia's foreign affairs and for her defense. In return for the use of certain Micronesian lands and the right to maintain a military force in Micronesia, the Joint Committee on Future Status proposed that an annual payment be made to Micronesia.

With respect to the executive function, after the compact of free association is signed and ratified by both sides, the position of high commissioner would be replaced by a corporate executive council, whose members would represent each of the six districts. This would constiture the highest level of policy-and decision-making in the new state of Micronesia. The executive council would elect a chairman from among its members who would serve for a predetermined period of time. The legislative and judicial areas would remain as they now are.

As the two sides have moved toward an accord, the regional differences within Micronesia have become more serious and dangerous to the internal unity of Micronesia.

At this point in time the general state of affairs in Micronesia can still be manipulated to make Micronesia hate what it loves and love what it hates. Micronesia knows that to survive in this world, it must stay together. The opposite is also true: it knows that to disband is to court troubles and problems.

The present Americanization of Micronesia is an unprecedented phenomenon in Micronesian history. The American penetration of and intrusion into the islands of Micronesia since 1944 has brought an incalculable amount of confusion and frustration, and damage to both people and materials. The Micronesians as a whole are gradually losing their sense of harmony and direction. There seems to be a serious lack of national leadership and national goals. There is litrle public participation in the important issues affecting Micronesia and her peoples; this aparhy has destroyed Micronesia's united front, which was strong and effective in the earlier days.

It would seem that the chief trait which characterizes the temper and mood in Micronesia today is impatience. "Tomorrow" has become a dirty word. The future is now; hope has turned into desire. The 
present young generation cannot see why it should wait any longer for a say in the domestic and international affairs of Micronesia.

Everywhere there is a quest for pride. Pride is the only currency that can buy souls. An undertaking or a cause will make headway in any district only if it generates pride.

The day when Micronesia will assume responsibility and govern itself is fast approaching. Micronesia must soon forget its minor internal differences.

Historically, these islands have always been isolated from one another. The presence of outsiders helped bring them together and made them a political entity. If the presence of an enemy is the only unifying force, then Micronesia must look inward to see what problems make it difficult for her to achieve unity on her own. The real enemies are poverty, disease, and illiteracy. These are the real challenge of this decade for Micronesia.

Throughout history, each generation has had to answer the summons of history. The American administration since its early days made its biggest mistake when it alienated the present generation of Micronesians who now control the political destiny of Micronesia. Their proclamation, their struggle for freedom against U.S. colonialism in Micronesia, is a direct result of three decades of mismanagement and mistreatment. It is a direct result of a policy of human containment in Micronesia.

In Koror, the U.S. delegation helped formalize the furure status of Micronesia by agreeing to the Micronesian demands. Now it is up to the Micronesian people themselves to decide on the life-style and the quality of life they want. This is the destiny of Micronesia. Some countries of the world have had to find their destiny in the battlefield, others by wars of liberation and conquest, and still others through the process of political evolution. In Micronesia, destiny had to be negotiated. Here, a people who claim sovereignty over their lands have had to do so in face-to-face confrontation over a negotiating table.

Micronesia emerged from the Palau talks as the future state of Micronesia in free association with the Unired States. In Palau, the world's most powerful nation met with the world's tiniest and weakest microstate. In their sessions, decisions were pursued and arrangements were reached on the future political status of Micronesia.

It is proposed now that upon the signing and ratification of the compact the state of Micronesia will be created and a constitutional convention will be called to draft the formal constitution of Micronesia.

The springtime of Micronesia's struggle for freedom and human 
dignity is virtually coming to a close. Changing its political status from trusteeship to free association, however, is only the beginning. There are problems awaiting the new state of Micronesia, problems of internal unification, the running of a scattered bureaucracy, and transition. Whether the new state of Micronesia will be able to cope with these problems is a matter of speculation at this point in time.

However, in light of the last quarter-century's experience under colonial powers, it is difficult to imagine that these small and scattered islands across the Micronesian waters would want to continue under the mediocre and apathetic parernalism of American colonialism. The vestiges of Western colonialism in the western Pacific are gradually fading away.

The new state of Micronesia is proposed as a balance berween annexation and independence, or, as one American observer states, it is "the middle road to freedom." To the Micronesian, it represents the ideal and perhaps the most realistic of the proposals and options for the political future of Micronesia. It is Micronesian independence disguised under the name of free association.

In this day and age there are real difficulties for all the ministates of the world. Their only hope for freedom and self-respect must depend to a great degree on the concept of "interdependence," for truly, there is no real independence in today's world. This is an era of cooperation and interdependence. No nation can ever really hope to be on its own. Micronesia recognizes this state of world affairs. Its option for free association with the United States speaks for itself.

The nature of the Micronesian struggle for freedom is less a struggle against the economic dominance of an outside power than it is a moral issue. The primacy of colonialism and the resulting loss of human dignity and self-respect have been more repugnant to the Micronesian people than their economic situation. The American grand design for dominance in Micronesia is gradually coming to an end.

The main preoccupation of Micronesia during the past four years of political status negotiations has been to try to redefine its political relationship with the United States. At Koror, in Palau, during the fourth round of talks, this redefinition was narrowed down to a reasonable certainty. In broad principle, Micronesia will enter into a relationship that allows it complete internal freedom, except in the areas of defense and foreign affairs. The United States will assume the responsibility in these two areas. She will represent Micronesia in all official government-to-government relationships and in international organizations which require official governmental participation. Micro- 
nesia would exercise foreign policy actions in many areas of purely local concern. Micronesia would be free to enter into any trade, economic, technical, and cultural negotiation with any country or regional organization, so long as these dealings did not involve direct government-to-government relationships.

It is becoming very clear that Micronesia is commencing a new experience in national self-government and national unity. Micronesia must now turn inward to redefine its own goals and strategy in political, social, and economic development areas.

In looking ahead to the final resolution of the Micronesian struggle for freedom and self-government, some important matters still remain unsolved. Further negotiations on these matters are necessary. The issues of finance, transition, termination, and ratification of the compact of free association need to be resolved.

In looking at the record of the past four years of negotiations, we can see that it has been Micronesia which has been more willing to compromise. The United States has not given anything away in the entire four rounds of formal negotiations. If the United States thinks that she has given to Micronesia such things as control of law, control of land, sovereignty, and so on, the Micronesians have reminded the United States that they are reclaiming these lost rights, which were temporarily and unwillingly vested in a postwar colonial government.

On the other hand, Micronesia has proposed to give the United States, as part of the compact of free association, the right to maintain a military presence in Micronesia and to exclude third countries from entering Micronesia. Micronesia has accepted the U.S. request that the United States handle foreign affairs and defense as part of its global responsibility to keep and insure peace in the Pacific area. However, Micronesia has proposed a safeguard, unilateral termination, which will come at a specified time and which will allow the revocation of the compact of free association by the people of Micronesia.

Furthermore, Micronesia has agreed to allow certain of its lands to be used for the stationing of U.S. military troops. And, at the same rime, the Joint Committee has noted the desire of the Marianas District to become part of the United States, a desire which the United States has reacted to with eager interest.

As is usual in international negotiations, Micronesia is asking for direct payment for all these concessions given to the United States. However, the United States, although it is involved in negotiations with a legal representative of the Micronesian people, is still acting as a colonial power acts toward a subject people. 


\section{Epilogue}

The Micronesians are not in these negotiations to ask for favors or to exchange their country and their political destiny in return for U.S. gratitude. The records of these talks have indicated that the Micronesians have been extremely civil and humane during the course of these negotiations.

I think this is about as far as the Micronesians will go in these talks. It is now up to the United States to show good faith by recognizing its peculiar role in Micronesia.

It is true that America came as both liberator and conqueror to Micronesia. However, its role as a conqueror ceased when the Trusteeship Agreement was signed in 1947. And its role as a trustee is now in its twilight.

Micronesia does not have too much time left. If it does not get its freedom in the immediate future, it will probably be too late. But there is hope, and even if the Congress of Micronesia cannot complete the task, the Congress must not abstain from it. The struggle for freedom will continue.

When the fifth round of negotiations ended in Washington, D.C., the Micronesian delegation came back home with a partial draft compact fully agreed to by both sides. Time did not allow the completion of the whole compact of free association. However, the Joint Committee on Future Status felt it ought to present the draft compact to the Congress for an early review.

The High Commissioner issued a proclamation calling for a special session of the Congress to be convened in Kolonia, Ponape District, in August 1972. This parricular special session proved to be a critical one. It created a real dilemma not only for the U.S. delegation but also for the Joint Committee on Future Status. The Congress passed the now famous Senate Joint Resolution 117, which directed the Joint Committee on Future Status to start negotiating with the U.S. delegation for an independent Micronesia. This new mandate was given as an addition, not a substitute.

Senate Joint Resolution 117 proved to be a real stumbling block at the sixth round of talks held at Barbers Point, Hawaii, in September 1972.

There are many reasons why the Congress of Micronesia suddenly changed horses in the middle of the stream by switching from supporting free association to requesting that the option of independence be explored. 1) The Congress was greatly disappointed with the partially completed draft compact. 2) This action was indicative of the growing sentiment within the Congress favoring full independence for 
Micronesia. 3) Those members of Congress who voted for the passage of Senate Joint Resolution 117 were greatly influenced by a group of self-appointed American advisors. 4) There was a real clash of personalities within the Congress as to who would get the credit for the political settlement if and when the task was completed.

Each one of the above reasons has merit worthy of consideration, but I rather think the reason was far deeper than most would like to speculate. It was the case of the difference between the rhetoric of politics and the reality of politics. The fine print in the partially completed draft compact held facts too appalling at the moment of truth.

Up to the time the partial draft compact was submitted to the Congress, the people of Micronesia and the Congress had talked about free association, and how nice it was that the U.S. government had consented to give Micronesia autonomy and that the United States would take care of all the other costly problems of defense and foreign affairs. Now for the first time Congress was presented with the partial draft compact which translated and transmitted everything about free association into written literature. The hard facts and realities of the proposal were too much for a Congress that had been dreaming all these past years. It seems to me that this is what happened to the Congress assembled in a special session in Ponape in August 1972. The gap between the rhetoric of free association and the hard realities translated into a compact was too great for an unprepared and unrealistic group of legislators. This turn of events, however, was to be expected. Congress and a sizable portion of the Micronesian people had been listening to descriptions of free association, but had never seen it on paper. When it did appear in print, they found that it sounded better than it read.

Thus, the special session in Ponape gave an additional mandate to the Joint Committee on Future Status. The negotiating committee had no choice but to accept this added mandate. After a short recess, the members of the joint committee began preparing for the sixth round of negotiations scheduled to be held at Barbers Point, Honolulu, Hawaii.

The fourth round of talks in Koror, Palau, had reached agreement on the broad principles governing the whole negotiation; the fifth round, the Washington talks, began the drafting of the compact; the sixth round of talks at Barbers Point was to continue with the task of completing the compact of free association. Instead, the sixth round centered largely upon procedural questions and nothing substantial was accomplished.

The implications of the special session in Ponape disturbed the American delegation to a considerable extent. The basic assumption 
held by each side concerning the nature of the joint negotiations, especially at the sixth round, was curtailed. At this point the Joint Committee on Future Status was forced by the turn of events to at least give some explanation to the rationale behind S.J.R. 117 and its effect on the joint negotiations, which it did as follows:

This language does not mean that we should not proceed toward the completion of a draft Compact. If there is any uncertainty, it is due to the fact that we cannot, of course, predict the ultimate reaction of the Congress and the people of Micronesia with regard to the Compact. We do not believe that this in and of itself alters, or should alter, either our basic approach or our murual resolve to arrive at a draft Compact satisfactory to both our delegations. ${ }^{1}$

This clarification informed and assured the American negotiating delegation that, although S.J.R. 117 was an added mandate, it did not change the basic resolution of the Micronesian delegation to proceed with the completion of the compact. The new mandate was complementary rather than contradictory.

Despite this assurance from the Micronesian delegation, the American delegation was still unconvinced. Indeed, the special session in Ponape overwhelmed the American delegation and caught it off guard. To a degree, the Micronesian delegation was similarly affected despite its attempt to rationalize its own position. However, this state of affairs should perhaps have been expected by the two negotiating delegations.

Both delegations operate on certain basic assumptions. The American delegation operates on instructions it receives from the White House and from the Departments of State, Defense, and Interior. The Joint Committee on Future Status must operate on mandates it receives from the Congress of Micronesia. This makes it somewhat difficult for delegations to negotiate if their instructions do not allow them flexibility to deal with sudden changes in policy. This was especially true in the case of the American delegation. The Joint Committee on Future Status whose orientation had been directed toward the resolution of the free association arrangement had more flexibility, and thus, was able to incorporate the Congress' new mandate. The American delegation's instructions, it seemed, allowed it no flexibility and it was thus unable to deal with the new issue of independence. As a consequence, both sides had great difficulty in carrying on with the talks at Barbers Point. It 
thus became necessary to temporarily recess the sixth round of negotiations.

There is high hope, however, that the compact of free association will be resolved when the seventh round of negotiations is resumed in 1973 , and in subsequent rounds of talks in late 1973, if they are necessary.

The Joint Commitree on Future Status has been willing and able to grapple with the issues facing the future of Micronesia. It has provided the bold and positive leadership that is so necessary. At this point, it could be said that Micronesia is at a crossroads. It is, therefore, more than ever before essential that Micronesia's growth and maturity should dictate that each district support the concept of free association under which the Joint Commitree on Future Status operates. The success or failure of this endeavor will not only affect the pages of recorded history, but also the lives of every Micronesian, and the life-style of the Micronesian society.

\section{National Unity}

As Micronesia comes closer and closer to making its final decision on the political arrangement between itself and the United States, and on the internal relationship of the five regional districts, the forces of internal conflict and disunity have emerged and entered the national debate.

In many ways, many of the difficulties in the Micronesian quest for order and national unity are products of gross misunderstanding and lack of appreciation from within Micronesia itself. There seems to be a strong desire on the part of some Micronesians and some districts to pursue a course of relative isolation within Micronesia itself and of Micronesia from the surrounding Pacific community. The cause of national unity is less imperiled by outside pressures than by selfish motives from within. There is little feeling of nationhood outside each of the regional communities.

In addition, the Congress of Micronesia has been unable to provide the kind of national leadership that is needed at this juncture. It has a tendency to dwell on the negative at the cost of the positive. It has let itself be motivated by self-appointed counselors and advisors from the outside, the non-Micronesians who dislike the American system, and who, therefore, are critical of that system. What should be recognized is that these self-appointed advocates are also American idealists who can afford to tear down their own system. They are part of a far more 


\section{Epilogue}

superior economic system and a much more stable political system. Their bitterness and discontent with the American system is not sufficient reason for Micronesia to accept or to even listen to their advocacy.

There are also the young Micronesians, their bitterness inflated and influenced by the current anti-Establishment revolution in the United States, who now feel they are in a position to advise Micronesia on the proper course to take.

Very few, if any, of these young Micronesian idealists and these self-appointed outside advisors know what life was like in the old Micronesian society, much less how it is to husk a coconut or chase a fish on the rough reefs of Micronesia with no shoes on. Micronesia can do well without these kinds of advice, for when times become hard, it will be the Micronesian who will suffer the consequences, not those who can afford to leave what their bitterness has wrought. On the other hand, Micronesia should accept the opinion of those outsiders who love their countries, yet are willing to tell Micronesia of their faults.

At this stage, it is difficult to see how Micronesia can afford to be idealistic in the face of the great adversities that must be surmounted. Micronesia should be looking forward, not backward. It must scrutinize its own system and not that of the Americans. Micronesia must learn the hard facts of her own social, economic, traditional, and political conditions. It is the existence of aspects of an old and archaic system in the midst of the twentieth century that has made Micronesia what she is today.

The issues that must be considered in determining Micronesia's future course are the same issues that have confronted generations of Micronesians and, in fact, societies the world over-poverty, illness, and ignorance. The question is not whether one form of political arrangement is superior to another, but rather which form of political association is most likely to help in the wars on poverty, illness, and ignorance. These are the problems facing Micronesia today, yesterday, and tomorrow.

The Congress of Micronesia cannot abrogate its role of providing national leadership in this time of great political crisis. The people will decide in a plebiscite what the form of association will be. If the Congress fails to provide guidance and direction, it can raise no quarrel with the decision of the people. A plebiscite may not be the best way to decide, but it is the democratic way.

For many nations, political independence is expected and unques- 
tioned. No one would challenge the right to independence of, for example, the Japanese or the Swiss. In the cases where independent statehood may be out of the question, these nations or subnations should exercise self-determination, within the limits of what is practicable and dictated by the circumstances. Micronesia has six regional communities, perhaps with six separate political consciousnesses. What is the best way to mold such diversity into a single independent entity? If Micronesia should opt for an independent state at this time, she will have destroyed all her chance for independence later on, because the Micronesia of today will cease to exist; each district will go its own way. For Micronesia, independence must come slowly and through a process of evolutionary growth. Micronesia needs time to mature, to assimilate and integrate her feelings and emotions into a viable whole.

If Micronesia becomes independent within the next two or three years, the Micronesia which we know today (the Trust Territory of the Pacific Islands) would disintegrate so fast that history would be hard put to record the transition. Palau would go its own way, as would the Marshalls and perhaps some other districts. There would be no reason for these districts to stay together if they were better able economically and politically to go it alone. It is for these reasons, therefore, that independence ought to await Micronesia's maturation, a time when the districts would give it their willing support.

\section{Free Association or Independence}

At the crossroads, the paths to free association and independence beckon. Which path should Micronesia take? This perhaps is the most challenging of the deliberations facing the Congress and the people of Micronesia.

It is argued here that the desire for independent status for Micronesia in this decade is both premature and highly divisive. It is premature because it is unrealistic at this time, at least in terms of the economic considerations. It is divisive because it impinges upon the development of national unity and political cohesiveness.

Free association on the other hand would provide Micronesia with a sense of continuity and evolurionary growth. It would provide a sense of security from within and from without. It would allow Micronesia time to experiment with the operation of her own internal government by relieving her of worries of the economic security of her people, or threat from outside, or natural disaster. This would be possible because the United States would continue to give aid in time of natural disaster, 
would make an annual payment to the new government of Micronesia for the military use of its lands, and would retain the responsibility for Micronesia's defense and foreign affairs.

Of the two choices, for all practical purposes, independence for Micronesia is a nice dream, a tale, a myth, an issue filled with emotion and a good subject for speeches. It would emancipate Micronesia's sense of pride in her past, but it could do little to eliminate the chronic misery of the Micronesian islands and their people.

Free association offers both a challenge and an opporrunity-a challenge that would test the capability and stability of Micronesian courage, leadership, and bureaucracy, an opportunity for evolutionary growth. It is a selection made out of necessity and the realities of the Micronesian situation.

Nationalism is a dangerous phenomenon. It has destroyed many young and aspiring independent countries in the underdeveloped world. It can also destroy Micronesia. In Micronesia, it is a passion that finds its roots in a buried past. It is one of the most effective brakes to progress. It is a soothing tonic to such things as traditional identity, tribal organization, caste system, traditional concept of family and pride in the number of children produced. While these traditional wonders may be fine, they will not help the cause of national unity in Micronesia. They have little regard for any sense of national brotherhood, development, and progress outside of their small groups.

The advocates of independence for Micronesia seem to think that all the blames for the ills and problems of Micronesia have their roots in colonialism, but Micronesia too must share some of the blame for her complete obsession with an archaic past.

More than at any other period, Micronesia now has the opportunity to make a complete social, economic, and political breakthrough with the opportunities available to her under the proposed arrangement of free association with the United States. Certainly there will be problems but they will be parts in relation to the whole. There are no plateaus in international affairs and negotiations. What is considered a utopia soon becomes the beginning of a decline. Micronesia will gain a few and lose a few. Flexibility is perhaps Micronesia's best hope as she looks toward the unknown.

Micronesia must not confuse form with substance, illusion with reality. Micronesia thus far has been able to make the transition from feudalism to a semimodern territory. Her main challenge now comes from a proposed move that will make her a larger community of islands, 
exchanging economic benefits among one another and sharing a common heritage in close and friendly political association.

Micronesia is very small and poor in terms of international affairs. History thus far has indicated clearly that small states survive only because great powers need them, as buffers, boundaries, and as a part of the balance of power and trade. Although many Micronesians would look at colonialism and readily attack it for the many ills it brought to Micronesia, nationalism is worse, for it has often viciously purged its state of elements that seem alien to itself. Nigerians slaughtered thousands of Ibos, thus triggering the Biafran revolt; the Nazis slaughtered millions of Jews. These were nationalists', not colonialists' acts. I have great reservation about the rising Micronesian nationalism because in it there is a dangerous element of hate directed toward Micronesia, as well as toward the United States. Thus, while sovereignty is highly desirable, it can also bring chaos because it breeds intense nationalism. There are more checks and balances in free association than in independence. In this context, Micronesia would do well to listen to what an authority on national self-determination had to say about the future of small states.

The dependence of small nations on the great powers is more absolute now than ever before. For most of the smaller nations in the modern world, moreover, a negative independence is not enough. The economic influence of the world powers is inescapable. This is the setting in which the independence of small states must operate. ${ }^{2}$

\section{A Sense of Purpose}

When the process of decolonization was first begun by Congress in 1967 , no one would have thought it possible that within a five-year period, this movement would become the main apostle of change for Micronesia. Within the next four years, the future political status of Micronesia should be settled. The strength and confidence is there, all that is needed is the moral support of the Micronesian public. In a way, many of the difficulties experienced in the quest for change in status have been a source of pride for Micronesia. The success enjoyed thus far is the result of the success of the Congress of Micronesia as a legislative body, and as an agent of change. Yet Micronesia should not make the mistake of resting on its laurels.

Micronesia must continue to work on her remaining problems, such as colonialism, poverty, and the lingering ways of the past that 
impede growth. Micronesa is now caught between the forces of modernization, the inevitable changes that are coming, and her own traditional past. Therein lies the greatest dilemma of Micronesia. Of its remaining problems, there is hope that Micronesia can cope with colonialism for a while, but one thing is certain, as soon as Micronesia will have gotten rid of colonialism, the other two problems will certainly emerge, and they are potentially more destructive. Micronesia has been united in fighting a common opponent, the United States, and thus has been fooled into thinking she has solved her problems because she has this sense of unity when, in fact, the unity is a very fragile one. The following illustrates Micronesia's dilemma very clearly. Peter Abrahams is a black novelist, born in Johannesburg. He has put the following into the mouth of his protagonist, an African leader.

"Our country has, or rather had, three enemies. Of one of these, I have made an ally. But let us say that there are three. The first of these is the white man. And then, there is poverty; and, finally, the past. These are our three enemies. When I came here, I thought that I would have to face only one enemy, the white man. But, as soon as I had gotten rid of him, the other two enemies appeared; and they are even more powerful and dangerous than the white man. Next to them, the white man seems almost an ally; and so, I have converted him into an ally who fights at our side against poverty. Now, he works for us, so that those who come after us will have bread and a place to live. There are now schools and hospitals in our land. Our young men and young women are beginning to awaken from their torpor. Why do you think I have spent so much money to send them to foreign lands? Because I need them to fight at my side against our third enemy, our worst enemy: the past. ... For the sake of appearances, I have performed the rites of juju; I have participared in blood ceremonies; and I have prostrated myself before the altars of our ancestors. But now, I will do so no longer. Now, there are enough young people who have put aside these outdated superstitions for me to be able to undertake the extirpation of everything that is ugly in our past. And you, Selina, and you Adhebhory, whom I once loved as a brother, you are of the past. I shall destroy you, because it is you who are the obstacle to the evolution of a greater Africa. Go, fight me in the party 
conference, and you will see who will win. You come too late, my friends. Too late. . . ."3

Micronesia's insecurity produced by centuries of subordination is not lessened by our discussing its manifestations any more than a tidal wave is understood by studying the surface of the ocean. Micronesia's goal becomes unattainable partly because we spend to much time worrying about colonialism and the past. Micronesia's greatest need now is a sense of purpose. Fifty years from now no one will care who was right with respect to our present political dilemma if in the process, Micronesia has torn herself to pieces.

\section{An Analysis of the Micronesian Dilemma}

After six rounds of political status negotiations and the recently concluded session of the Fifth Congress of Micronesia, 1973, it is safe to say that the complexity of Micronesia's political dilemma has been intensified as the forces of separation continue to haunt the members of the Congress of Micronesia. Victory and success in the negotiations would be only the beginning of the real effort here at home. Whatever compact of free association is agreed upon, it must win the enthusiastic support of the Congress and the people of Micronesia. For the most part, the real cause of this political dilemma may be found within Micronesia.

In 1970, in an article that appeared in Pacific Islands Monthly, I made the observation that "Congress was confused about what it wants." Now, two years later, and with the imprint of the Fifth Congress of Micronesia still fresh in people's minds, there seems to be no reason to change that observation.

As the time for deciding the political settlement becomes nearer, the forces of disagreement and fragmentation within Micronesia have become greater. It is now possible to foresee the reaching of an accord with the U.S. delegation but, unfortunately, this is not true of winning the approval of the Congress and the people.

The refusal of the Fifth Congress to give final approval to the three measures sponsored by the Joint Committee on Future Status, namely, the bills to establish a constitutional convention, the Office of Transition, and the Commission on National Unity, has set back the final resolution of the status issue to where it was two years ago. In fact, it has weakened the position of the Joint Committee on Future Status in the eyes of the U.S. delegation and the people of Micronesia. The United States cannot help but wonder who and what the Joint Committee 


\section{Epilogue}

represents. This is not the fault of the Joint Committee. It is a failure of the Congress to provide leadership and guidance. It resulted from misunderstandings, and perhaps from political power plays by individual members of the Congress interested in demonstrating their control, power, and influence. This, perhaps, is to be expected in a legislative body whose members come from varied ethnic and political backgrounds. It is sad that a national goal was sacrificed in the interest of local politics. The greatest good for the greatest number should be the order of the day in Micronesia in this century.

The Fifth Congress, for all practical purposes, failed to consider the most important issue before it-the resolution of the political status of Micronesia. The Congress had decided in 1969 that the time had come to start decolonization of Micronesia. In order to do this, the Political Status Commission was created with members from both houses and representatives from each district delegation. The mandates given the present Joint Committee on Future Status through several bills and resolutions are straightforward and unequivocal; they are the four basic principles and legal rights discussed at length in earlier chapters. The most important of these mandated the committee to negotiate a compact of free association with the United States, failing this, the committee was mandated to negotiate for Micronesia's independence.

This has been the position of the Joint Committee on Future Status all along. However, in order to accomplish this end it was necessary for Micronesia to acquire the instruments necessary for the transition to self-government. There would need to be a constitutional convention, and an Office of Transition, to set the objectives of self-government. As envisioned, the Commission on National Unity is a by-product of these two major agencies. The question of national unity has always been a major factor in the topic of self-government. Thus, if Micronesia is to begin drafting her constitution and is to begin empowering the machinery of transition, then it is absolutely essential that the problems which are the sources of disunity and dissatisfaction among Micronesians also must be taken into serious consideration. The Commission on National Unity would be charged with the task of examining and solving these problems.

The causes of Micronesia's political dilemma must be looked at in the context of the relationship between the Congress and the Joint Committee. The committee is neither parochial nor regional in ourlook. It views its mission as being national in character and acts accordingly. The Fifth Congress by comparison is regionalistic in outlook, illustrated by its passage of insignificant pieces of legislation and a great number of 
pork barrel bills. While the Joint Committee was looking at the forest, the members of the parent body, the Congress, were looking at their respective trees.

The president of the Senate, Senator Tosiwo Nakayama, called upon his fellow senators and fellow Micronesians to "wake up" from their twenty-six years of sleeping. Apparently, no one wants to wake up. The chairman of the Joint Committee, Senator Lazarus Salii, in a speech on the floor of the Senate, with members of the 1973 U.N. Visiting Mission sitting in the public gallery, sought to reach his fellow senators by saying "Micronesians should be masters of their own destiny, and be first-class cirizens in their own islands under their own constitution." He closed his remarks by commenting on the importance of a constitution, "I believe it is time that the people of our territory join hands and try to fashion a constitution-a constitution which I hope will establish for the first time a truly legal framework for these islands. In our quest for a constitutional form of government, we must not also forget a constitution cannot do its work unless the people are united behind it. To provide unity for the people of Micronesia, we must lay the foundation for social justice in Micronesia."

The lawmakers decided that there was not enough money to start building the foundation of their future government. It is interesting to note here that in 1972 at the special session in Ponape, an identical bill was introduced; it failed passage for the same reason: insufficient funds. Curiously, in that same session the lawmakers voted themselves an increase in salary from $\$ 8,000$ to $\$ 12,000$, a $\$ 4,000$ increase totaling $\$ 132,000$ a year. Again, during the January 1973 session, the bill was brought up for action and again there were insufficient funds, and again lawmakers sought increases for themselves, this time attempting to raise their office expense allotments from $\$ 2,500$ to $\$ 3,500$, a $\$ 1,000$ increase (or $\$ 33,000$ a year). This measure however failed in the Senate. One begins to wonder if Micronesia is not gradually developing a very elitist and self-serving system of government.

Each member of the Congress of Micronesia wants to establish as policy what he thinks should be the set of priorities for Micronesia. One thing should be understood and made clear to all-the only real priority for Micronesia over the next five years is the political status issue and unless this issue is resolved, all other matters in Micronesia are secondary in nature.

The major causes of Micronesia's political dilemma are many. However, it is my position that Micronesia's dilemma and her inability to come to a consensus of opinion regarding her future political status 
can be traced to six major areas: 1) the confrontation of the Old and the New; 2) the nature of U.S. policy and the status of Micronesia; 3) the argument over which comes first, economic or political development; 4) unity versus fragmentation; 5) the curse of geography; and 6) arrogance of power.

\section{The Old and the New}

Micronesia as a whole is reluctant to accept change or to embrace what is new. It is in the nature of human beings to fear the unfamiliar and strange. The great majority of Micronesians would rather not bother with the world; they would prefer to stay home and go fishing. It is this general attitude that is delaying our national development. The young generation is used to a modernized way of life yet ideologically it wants to say "Yankee go home!" It is a paradox. A generation of Micronesians who have never lived on a coconut economy want to advocate it because it fits what they have learned of the Western world in their classrooms, namely, that outsiders are guilty of corrupting and colonizing Micronesians. But the young generation operates in the present, in the new Micronesia, the Micronesia that depends on imported goods.

The old folks are set in their own ways, they are beyond reach by any means, yet the old folks are fascinated by the new way of life or what has been brought to Micronesia. The old leave the decisions to the elected leaders; the young want more control and leaders responsive to the electorate. Only the rational man in Micronesia can guide Micronesia. As a thinking man, his way would be to take Micronesia through a middle course. His sense of reality makes him reject complete independence or complete Americanization. He wants free association as being the closest to a synthesis of the two.

\section{U.S. Policy and Micronesia's International Status}

Micronesia is neither a U.S. territory nor is it a sovereign independent state. The Micronesian claims ownership and sovereignty of Micronesia. The American claims Micronesia by the right of conquest, but that claim ceased to exist when the United States entered into a trustee agreement with the United Nations for the governing of this area. Thus, all U.S. policies toward Micronesia are affected by this strange situation.

If the United States fails to promote the development and the well-being of the people of Micronesia, she is charged by Micronesians with neglect and irresponsibility. On the other hand, if programs and 
development are promoted, the United States is accused of making Micronesia more dependent on American aid. This is a real dilemma which the Congress seems to ignore by failing to enact legislation designed to resolve such a dilemma.

\section{Economic or Political Development?}

There are those who say that for the next five or ten years Micronesia should forego all political activities for the sake of economic development. This view is as interesting as it is naive. Were the real economic and political circumstances in Micronesia not what they are, this view might have some validity.

One of the most important aspects of the current negotiations is the element of time. Time is on their side, not ours. The longer Micronesia waits to settle its political problems, the greater the impact of American aid upon Micronesia will be. And under such circumstances, Micronesia will have no choice but to choose integration with a far more superior economic system. Alternatively, if, as seems to be the current trend, aid is reduced, then development will be hurt.

The sooner the compact of free association is approved and ratified, the sooner the process of economic development can be instituted and controlled by Micronesians. If, on the other hand, we stop negotiations on the future status, and allow American aid, or economic assistance from some other outside source, to enter Micronesia, then Micronesia will become a political pawn easily maneuvered by the international powers.

The accepted view of economic development for Micronesia involves the massive inflow of outside capital to help develop the economy. This is an orthodox view, and one that has not proven itself. At least, it has not brought about great improvement in Micronesia during the past twenty-odd years; it has made Micronesia more and more dependent on the big countries providing the capital.

The U.S.-based Van Camp firm has a fishing operation in Palau, but Palau's fishing economy is no better developed than those of the other districts. Yet, the Van Camp operation represents the investment of huge quantities of outside capital funds. What has happened is that Palauan offshore waters are being drained of their resources and, because the fish is taken to American Samoa for processing, American Samoans are earning a livelihood from fish caught in Palauan waters. These fish are returned to Palau in small tuna cans and sold for a fantastic price. How has the investment of outside capital funds helped Palau in this case? 
I lean toward the view of economic development that states that underdevelopment in an economy is not an original state. The economic and social structure of underdevelopment are the products of the cultivation of colonial dependency in their colonies by colonizing countries. The reason for this lies principally in the character of the relationships between the colonizer and the colonized.

If Micronesia continues to court rich outside corporations, her economy may become oriented to the export of certain primary products (such as fish), which would be under the control of foreign capital or companies, and which would reenter Micronesia as imported goods (canned tuna fish). Outside capital would develop transportation and dock facilities and utilities only to the extent necessary to complement the export sector under their control. And this dependence upon the money-supplying power would also shape the social structure of underdevelopment.

The only way Micronesia can develop economically is by starting with small firms and corporations built mainly by Micronesian investments. What is important is not the dollar amount, but the direction and approach: they must be Micronesian in orientation.

\section{Unity versus Fragmentation}

Of all the problems facing Micronesia, the achievement of unity is the greatest. It is another of the many dilemmas that Micronesia must resolve before the Trusteeship Agreement is terminated.

Many people in Micronesia assume that Micronesia is united. On the surface it may seem that way, but within the pyramid of Micronesian history and culture, it is not. There are deep resentments and feelings of antagonism among the six major ethnic groups of Micronesia. Pride in district precedes all others, and when one district attempts to dominate another, it is almost always resisted by the other districts. There is very little national pride in Micronesia; what there is of it exists mainly among the younger generation who went to school together first in and then later outside of Micronesia.

For selfish reasons, there are those in Micronesia who want to fragmentize her. If this should happen the Micronesia we know will cease to exist. There are those in one district who would opt for a close affiliation with Japan, as there are those in another district who want to join with the independent Republic of Nauru, or with Hawaii as an addition to the county of Maui. This is preposterous. The president of Nauru would be unwise to agree to a union with the Marshalls, for undoubredly he would soon be voted out of office by the more populous 
Marshallese. As for joining Hawaii, I would think it preferable to have a president in the Marshalls than a mayor (the chief executive at Hawaii's county level). For Palau to entertain the idea of affliation with Japan is extremely dangerous, not only to herself, but to the rest of Micronesia as well.

These ideas of fragmentizing Micronesia arise from selfish motives. However, Micronesians, as a race, have a good chance of developing a small Pacific nation if they can only recognize the meaning and the benefits of unification.

\section{The Curse of Geography}

Micronesia is at the same time cursed and blessed by her geographic circumstances. Her sense of unity is frustrated by her own geography, yet the waters that divide her islands and make difficult her unification are the same waters her people set sail upon to discover each other.

The task of unifying Micronesia is made difficult not only because of her special geographic characteristics, but also because of her many cultures. The challenge nature has imposed on these islands is less a problem than the cultural one. Science and technology are gradually making Micronesia smaller and smaller. Entrenched ignorance and arrogance, on the other hand, are not that easily conquered.

\section{Arrogance of Power}

From the end of World War II until now, Micronesia has experienced nothing but an easy life-a hand-out type of existence. Everything Micronesia has wanted, Micronesia has gotten. The U.S. Navy gave Micronesia much in the way of material goods, and although the Interior Department has not been able to equal the navy's generosity, it has given virtually every educated Micronesian that educarion at no cost, a gift that Micronesians have been asked to repay not in dollars but in public service to their own people. In addition, every year since 1945 millions of dollars have been given to Micronesia, making Micronesia and Micronesians beneficiaries of a false economy, but nevertheless, an economy in which people do not have to worry about their future.

Micronesian economists, bankers, government officials-all have not had to worry about the state of the Micronesian economy. There is no reason to worry: each year the U.S.' Treasury Department hands out a check to Micronesia.

For over twenty years, Micronesians have been living in a welfare 
state. They have been conditioned to believe that what they have, or what is given them, is their due. Very few Micronesians have ever really earned a decent living, for everything is given. The Congress of Micronesia, through its Joint Committee on Program and Budget Planning, has been given a peculiar role with regard to the federal budget: an opportunity to look over the budget given to Micronesia each year. It is a role which has given the Congress a false sense of pride, since the only thing the Joint Committee on Program and Budget Planning can do is set priorities within Micronesia. It cannot basically change, increase, or decrease the budget. It may alter it, but in very small ways indeed.

In other words, Micronesia is a puppet subject to the manipulations of overall U.S. budgetary considerations and the very life of Micronesia is dependent upon the ups and downs of Washington thinking.

When the Congress of Micronesia in 1967 determined to decolonize Micronesia, it, in fact, made the decision to confront its own master and creator.

In the beginning, the people and their Congress were united in their efforts. Micronesians gradually began to gain self-confidence; they were, after all, challenging a giant. However, something went wrong. The Congress' own Joint Committee on Future Status, charged with recommending an appropriate political course, is finding it extremely difficult to move ahead. It seems that each and every lawmaker wants to have his say, wants to make his impact on the course of Micronesia's political future. It is a case of one Micronesian's stubbornness, ignorance, and arrogance pitted against that of another. No sense of purpose is served at all.

No more vivid example of thoughtlessness and arrogance can be conceived than the conduct that has recently characterized certain members of the Joint Committee on Future Status. In the ground rules governing the committee's operations, it was understood, by gentlemen's agreement, that everyone in the committee would support the majority opinion in negotiations and in the Congress. The agreement, however, has not been honored. Instead, shrewd behind-rhe-scene politicking has been the rule.

In the final analysis, the root cause of the difficulties in the quest for change in political status exists not solely in the accomplishments or lack thereof of the Joint Commitree or the Congress, but also deep within the Micronesian national character.

There is an irrationality and an impulsiveness about our people which often results in actions that are disharmonious and contradictory. 
A long tradition of isolationism and provincialism makes us narrowminded and dogmatic, reluctant to discard prejudices and slow to adopt even necessary changes and improvements if they embody a new concept. Indecisive and hesitant, we succumb readily to conceit. Opportunistic, but lacking a spirit of daring and independence, we are wont to place reliance on others. Our want of rationality often leads us to confused desires and a confused view of reality, and thus we do things without careful planning. We have a false sense of pride; when American visitors come to our houses or villages, we start talking in English to them and to our dogs, speaking in native tongue only to our small children. In short, as a nation or race, we lack the maturity of mind and the necessary condirioning to enable us to know when and what to sacrifice to achieve our goal.

Dag Hammarskjöld once said "The longest journey is the journey inward." Micronesia need not journey long to find her real enemy. In many ways, we, her people, are her enemy.

However, there is hope that Micronesia's political leaders will rise to the situation and lead Micronesia onward, for I believe that when hope has gone life has ended, actually or potentially.

What I have recorded here is a society in transition: the emergence of a new Micronesia. Micronesia had evolved slowly, in relative isolation, for many centuries, but during the last three decades the pace of change quickened as she was exposed fully and continuously to new institutions, attitudes, and ways of thinking and of doing things.

The American attitude toward the Micronesian political dilemma creates both a danger and an opportunity for Micronesia. It is potentially dangerous because it may cause the United States Congress to increase federal spending as an effective way of gaining the popular goodwill of the people of Micronesia. Micronesia needs to become more self-reliant, not more dependent.

On the other hand, the American attitude offers opportunity for Micronesia because it will make the United States government increasingly sensitive to the Micronesian point of view. The Congress of Micronesia through the Joint Committee on Future Status has made it known that Micronesia seeks far more than just increased aid. Her goal is self-government, and the self-respect and human dignity that are incumbent upon it. It will be difficult for the United States to ignore this request.

It is in the interest of Micronesia that her leaders and her people stay together, because as the late Professor J. W. Davidson, former consultant to the Joint Committee on Future Status, once observed: 


\section{Epilogue}

"The government intends that the United States shall remain in Micronesia on terms satisfactory to herself. The freedorn of Micronesia must be sacrificed in the interests-as these are currently interpreted in Washington—of international peace and security." 4

NOTES

1. Proceedings of the Sixth Round of Negotiations, Future Political Status Commission of Micronesia, Saipan, Mariana Islands, November 1972, p. 13.

2. Alfred Cobban, The Nation State and National Self-Determination (New York: Thomas Y. Crowell, 1969), pp. 308-309.

3. Jean-Francois Revel, Without Marx or Jesus (Garden City, N.Y.: Doubleday \& Co., 1970), pp. 67-68.

4. J. W. Davidson, "The Decolonization of Oceania," The Journal of Pacific History, vol. 6 (1971), p. 147. 
We wish to emphasize bere, bowever, that although the micronesians themselves must work out for themselves what kind of future links they wish to bave with one another, the Postscript administration is still at tbis stage obligated to promote national unity in every way possible.

Report of the United Nations $V$ isiting Mission to Micronesia-1973

AS THIS BOOK was getting ready to go to press, political events of great consequence developed in two district legislatures, the Marshall Islands Nitijela [Marshallese for district legislature] and the Palau District Legislature, which are bound to have great effects on the current series of political status negotiations with the United States, the whole question of U.S.-Micronesia relations, and the internal stability of Micronesia. The two district legislatures adopted several resolutions that consider the possibility of separate negotiations with the United States. Following this development, Ambassador Franklin Haydn Williams stated that although the United States will not impose unity upon Micronesia, the "United States continues to believe that despite considerable cultural diversity and differing local problems and interests, a unified Micronesia would best meet the economic, social, and other needs of the people concerned."

As far as the Joint Committee on Future Status is concerned, this new development is politically troublesome and clearly illegal, and a cause of major concern, not only to the nature of the negotiations with the United States but to the very unity of Micronesia. In chapters 16 and $17, \mathrm{l}$ examined the dangers posed by the issues of Micronesian unification and the challenge of leadership, especially at this period in our political development. I wish now to take a closer look at the situation in terms of irs political and legal implications.

The recent separatist movements in the Marshalls and Palau are significant because they may succeed in turning back the clock as far as negotiations with the United States are concerned. The same old problems pointed out in chapters 16 and 17, unification and leadership, 
arise again. Unification is a basic problem in Micronesia, but it can be achieved if forceful and enlightened leadership is exercised at the national and local levels.

Basic to the dissatisfaction in the Marshalls and Palau are the economic considerations. The Palauans view their economic problems in terms of their land and how much the United States is willing to compensate them for use of these lands. Thus, they ask, Who has ownership rights in Palau? The original owners or the present Trust Territory government? The government continues to say that it is holding these lands in trust for the Palauans.

The situation in the Marshalls is quite different. A small sector of the Marshallese people, especially the traditional leaders, has been enjoying the benefits of U.S. military presence on Kwajalein atoll.

The Marshallese are not complaining about United States' acquisition of their lands for military use. Their concern is with local tax revenues, the largest in the Trust Territory, which derives mainly from U.S. personnel living on Kwajalein. This money goes to the Treasury of the Congress of Micronesia, and some Marshallese leaders have requested several times that the Congress return 50 percent of this tax money to the local legislature. The Congress has refused this request each time. As a consequence, Marshallese leaders decided in April 1973 to go on their own. The district administrator has not signed the legislation into law as of this writing; if he does sign it, he will in fact be signing an illegal piece of legislation.

\section{Political Aspect}

The question of separatism in Micronesia is an issue of reality. No one is unaware of it. It has always been in the minds of Micronesian leaders. It is the main issue that is causing a great deal of difficulty in Micronesia today. It is not a new issue, but it is one that has come to the fore within the past six or seven years. It is true that the Marianas have always wanted to rejoin their cousins in Guam, at least this is the reason advanced by the Marianas as the basis for their decision not to join with the rest of the districts of Micronesia. Politically, I think this is a legitimate reason. However, I disagree with the timing and the manner in which it has been handled, particularly the way in which the United States has eagerly embraced the situation. It looks as though the trustee is colonizing the beneficiary.

The actions of the Marshallese and the Palauans are motivated by the political realities of their two districts. They look at their respective economic situations and think how they may be better off if they were 
allowed to control it. On one level this may appear to have some benefits. However, from the standpoint of international relations and especially of Pacific Islands' and Pacific Ocean area politics, it would seem very unwise and impractical. These islands of Micronesia are so small, almost negligible and powerless in terms of world politics and the realities of modern day life, that their only chance of survival in the realm of politics is to work together as a unit. Their slender natural resources, when combined, provide them a stronger bargaining position in the Pacific and in the world than when these resources are shredded into little pieces.

All separatist movements in Micronesia while the trusteeship agreement is still in force are without basis in law. They may be politically sound but there is little in Micronesia's recent history of legal precedence to support their legal existence. The Congress of Micronesia, the highest legislative body in Micronesia, was allowed or permitted to exist by Secretarial Order 2819 of the Department of the Interior; the authority creating the administration of the Trust Territory of the Pacific Islands is derived from Executive Order 11021 by the president of the United States. The president derives his power as regards the Trust Territory from a congressional enabling act of the United States Congress (Title 48, Chapter 14, U.S.C.). This congressional enabling act authorizes the president to approve, on behalf of the United States, the present trusteeship agreement between the United States and the U.N. Security Council. All these legal documents treat Micronesia as one single political entity. There are no such legal documents existing for each of the six districts individually. The districts can claim legal protection under these documents only as the Trust Territory of the Pacific Islands (Micronesia).

Clearly, there is nothing in these legal documents that can give support to a single district in its claim for a separate status in negotiations or otherwise. Furthermore, the Trust Territory code clearly spells out the authority of the district legislatures. The district legislatures of Micronesia are legislatures of a specifid nature. On the other hand, the Congress of Micronesia, similar to the United States Congress, legislates for the whole territory. It is the only one with authority to enter into any negotiation on behalf of the whole territory with a foreign power. Acts of the Congress of Micronesia supercede all acts of the district legislatures, and no district legislature can introduce legislation that is inconsistent or contrary to those of the Congress of Micronesia.

It is therefore highly questionable whether the United States or 
any of its federal agencies can enter into separate negotiations with an individual district. The United States has no property or governance rights in any of the six districts, except in its capacity as trustee for the Trust Territory as a whole. The United States has implied, at times, in its interpretation of the trusteeship agreement that the clause "maintenance of international peace and security" takes precedence over the clause "to foster political development toward self-government or independence."

True, Micronesia is a creature of circumstances of history, but it is also true historically that the League of Nations and the Japanese mandate regarded Micronesia as a single unit, and the United Nations and the United States trusteeship now recognize it as such. The United Nations has had precedence set that when a trust territory holds a plebiscite to determine its future political status, it does so as a unit.

It is my feeling that the United Nations will not look favorably upon the trustee (United States) that tries to pry off parts of the territory and form liaisons to its own benefit, regardless of whether the overture was initiated by the district. The right of self-determination in Micronesia belongs to the unit, not its parts. It must be exercised at one time on a given date by all the districts throughout Micronesia. The right of self-determination is possessed by the Micronesian people collectively. It will not come one district at a time. Is there a limit to how far the right of self-determination can be carried out? If not, we must remember that there are over two thousand islands throughout Micronesia that may possibly wish to exercise this right. The question of separate status for each district is an internal one-and, one $I$ believe, that can only be exercised at the termination of the trusteeship agreement, not before.

Because it is a decision to be made within Micronesia, the United States acts improperly in entering into separate negotiations with individual districts. The issue is only made more complicated by United States' acknowledgment of these illegal requests. The United States has a serious responsibility to see that the trusteeship agreement is honorably terminated for the Trust Territory as a whole. After that she can enter into separate negotiations with as many districts as she wishes. I wonder if this is not the better approach for the United States and her basic interests in Micronesia.

The nature of a trust is that the trustee enjoys no rights against the beneficiary. It is my conclusion that the United States is colonizing in the Marianas; and the same would be true if she should enter into separate negotiations with Palau or the Marshalls. I also believe that it is 
illegal for any district to attempt to enter into separate negotiations with the United States without authority from the Congress of Micronesia. Furthermore, I believe the United States has a sacred responsibility to ensure that Micronesia remains unified, not divided. The United States is just as much a creature of the trusteeship agreement as Micronesia is, and she cannot afford to violate that trust without causing serious legal and moral charges to be brought against herself in the international community.

In restropect, the adventure of change may be a tragic adventure for many - a sad uprooting of cherished customs and institutions. Yet, change is the one constant of history. It has certainly been the dominating factor in the development of Micronesia during the past three decades. The future does not belong to those who are content with today, those who are apathetic toward common problems and their fellowmen alike, those who are timid and fearful in the face of new ideas and bold adventures. Rather, it will belong to those who can blend passion, reason, and courage in a personal commitment to the ideals of Micronesian society. It will belong to those who see that the political future of Micronesia can only emerge from the clash of contending views, the passionate expression of deep and often hostile beliefs. The passion for freedom and self-determination for Micronesia and her citizens is the ultimate weapon in the Micronesians' struggle for human dignity.

For many years to come, scholars, historians, politicians, Micronesians, as well as Americans, shall continue to debate the future of Micronesia politically or otherwise. What is the proper political arrangement for a people lumped together by the colonizing hands of great powers. I have no reservations that the great majority of the Micronesian people have in them a strong desire to remain a united people. I do have reservations, however, about whether the Micronesian national experience, enriched and yet plagued by its diversity of cultures and customs, has been given the proper test of time. Because of this one must ask whether democracy, at this point in time, is an importable commodity to Micronesia. I hope I am wrong. Micronesia will eventually receive her freedom from the United States or from her own traditional past. She will have self-government and/or independence. These are, however, no guarantee that Micronesia will have a stable government, republican in form and strength. Very few nations of the non-Western world have been able to successfully import democracy. The separatist movements throughout Micronesia today are nothing more than a manifestation of the Micronesian objection to, and rejection 


\section{Postscript}

of, especially by the chiefs and the older generation, the imposition of a new order on Micronesia, whether it is in the language of the compact, the activities of the Joint Committee on Future Status and the Congress of Micronesia, or through the control of land by the administering authority. The Micronesians in this way are saying, "No thanks, in no way are you going to tell me what my future shall be."

Micronesia has been summoned by the forces of history; it cannot afford to stand still. It must take a stand on the political status issue as well as on the quest for national unification. This calls for creative innovation, imagination, and national leadership of the highest order. I have faith and confidence in the new Micronesia that is emerging and that the people of Micronesia will rise to the summons of history. 


\section{Major Political Events in the \\ Appendix 1. Process of Decolonization Since \\ 1967}

Summer 1967

Senate Joint Resolution 25 adopted. Introduced by Senator Bailey Olter of Ponape. This resolution created the first Future Political Status Commission.

January 21, 1968

The commission met with members of the House Subcommittee on Territorial and Insular Affairs, U.S. Congress, in Saipan, Mariana Islands.

\section{January 25,1968}

The commission met with members of the Senate.Subcommittee on Interior and Insular Affairs, U.S. Congress, in Saipan, Mariana Islands.

$$
\text { January 27, } 1968
$$

Members of the commission again met in Saipan; the then Representative Lazarus Salii, its first chairman. Dr. Norman Meller of the University of Hawaii was called to Saipan for the first meeting of the commission to discuss the range and alternatives of political status open to Micronesia.

$$
\text { July } 8,1968
$$

The commission presented its first "Interim Report" to the Congress of Micronesia.

$$
\text { January } 1969
$$

Dr. J. W. Davidson of Australian National Universiry was retained as consultant to the status commission.

\section{March-April 1969}

The Future Political Status Commission traveled to the islands and countries of the South Pacific to study and observe various political systems in the Pacific area. 
July 1969

The status commission presented its "Second Report to the Congress of Micronesia," recommending free association as the political choice for Micronesia. Congress accepted this choice when it adopted the "Second Report" of the commission. The "Statement of Intent" was aired throughout Micronesia.

\section{August 1969}

The Political Status Delegation was created under P.L. 3C-15, and by Senate Joint Resolution 63. The delegation's mission was defined.

October 1969

The Political Status Delegation went to Washington after it was recommissioned under this new name. The eleven points were presented in Washington. Senator Salii, who won reelection the year before, was again appointed as chairman. This marked the first round of talks on the future of Micronesia.

\section{May 1970}

The second round of talks was held at Saipan, Mariana Islands. The U.S. negotiating team was headed by. Assistant Secretary of the Interior Harrison Loesch. The United States made its offer of a commonwealth status for Micronesia, and rejected the Micronesian proposal of free association.

$$
\text { July-August } 1970
$$

The Congress of Micronesia convened in Saipan. The U.S. offer of commonwealth was the subject of bitter objection and was finally rejected by the whole Congress, except the Marianas delegation. Since then the position of the Mariana Islands has been out of line with the rest of the other five districts. It became clear that Marianas is opting for complete reintegration with Guam and the United States. The "Third Report" to the Congress on the question of status and proposals for termination of the trusteeship agreement, and the manner of adoption of a new constitution, was offered and adopted.

The Joint Committee on Future Status was created by House Joint Resolution 102. Senator Lazarus Salii and Representative Ekpap Silk were elected cochairmen.

Under H.J.R. 87, the Congress of Micronesia endorsed the "Four Principles" of Micronesian legal rights.

\section{January 1971}

The Congress of Micronesia again convened in Saipan, under a new Secretarial Order, giving it fifty calendar days of work. Discussions on political status during this session were cut short when the Congress of Micronesia building burned and the session adjourned. 


\section{May 1971}

High Commissioner Johnston called for a special session, held on the island of Truk. It was during this historic session that the Joint Committee on Future Status came under heavy attack as it got ready to meet with Ambassador Franklin Williams, a newly appointed representative of President Nixon to the starus negotiarions. At the same time, the "Independence Coalition," advocating complete independence, was formed in Truk. All Trukese members of Congress were the first members and several others joined from Palau, the Marshalls, and Ponape. Dr. Thomas Gladwin was retained by the Truk delegarion as their advisor, and subsequently by the whole commitree.

Senator Salii announced the appointment of Dr. Eugene Mihaly of the University of California, and Carl Heine, deputy district administrator, Yap, as consultant and staff director respectively, of the Joint Committee on Future Status. Professor J. W. Davidson was again reappointed to his role as consultant. Dr. Gladwin was asked to write a paper on the alternative of independence.

\section{July 1971}

A special subcommittee was created and asked to travel to Japan, headed by Senator Tosiwo Nakayama. It submitted a report on future trade relations with Japan.

\section{October 4-12, 1971}

The third round of talks, the first with Ambassador Williams, held its negotiations on the island of Maui, Hawaii. Senator Lazarus Salii and Representative Ekpap Silk, cochairmen, led the Micronesian negotiating committee. For the first time, the United States came around to giving recognition to Micronesia's quest for self-government.

\section{April 2-13, 1972}

The fourth round of talks was held in Koror, Palau District, in Micronesia. In principle, the U.S. delegation finally accepted the last of the conditions laid down by the people of Micronesia-unilateral termination of the compact.

Paul Warnke, a distinguished Washington lawyer, was retained by the joint committee as its legal consultant.

\section{July 12-August 1,1972}

Fifth round of talks was held in Washington, D.C., for one month. This round of talks produced the first draft of the compact of free association.

\section{August 14-September 2, 1972}

The High Commissioner called for the second special session to be held in Kolonia, Ponape District, to consider the issues of political status, and the report of the Washington talks. Strong opposition to the partially drafted compact developed and the introduction of S.J.R. 117 on independence was the highlight 


\section{0}

of the special session. Political maneuvering within and without Congress caused unnecessary delay in the work of the joint committee.

\section{Seprember 28-October 6, 1972}

Sixth round of status negotiations held at Barbers Point, Honolulu, Hawaii. This round of talks centered largely on procedural questions and basic assumptions held by both sides. The special session in Ponape earlier had created a real dilemma for both sides, and thus caused delay in proceeding with substantive matters.

\section{January 13-February 27, 1973}

The Fifth Congress of Micronesia convened in Saipan, Mariana Islands, returning for the first time since it was made homeless when its chambers were set on fire in February 1971. The Fifth Congress was a "do-nothing" Congress. It passed nothing of great significance. The Joint Commirtee on Future Starus experienced one of its greatest disappointments when the Congress refused to pass legislation strategic to the whole issue of political status negotiations.

The seventh round of status negotiations has been tentatively scheduled to be held in October 1973, to consider the remaining issues of the compact of free association, namely, finance, termination, and U.S. land requirements in the district of Palau. The exact time and place of this seventh round has not yet been decided, at the time of this writing. 


\section{Appendix 2. $\quad \begin{aligned} & \text { Statement of Intent of Future } \\ & \text { Political Status Commission }\end{aligned}$}

TWENTY-TWO years ago, when the islands of Micronesia were constituted as the Trust Territory of the Pacific Islands and placed under American administration, the United Nations directed that the administering authority "promote the development of the inhabitants of the Trust Territory toward self-government or independence as may be appropriate to the particular circumstances of the Trust Territory and its peoples and the freely expressed wishes of the people concerned." At that time, when the traumatic damage and dislocation of war had barely passed, when the distance between the Territory's six districts seemed so great as to call into question the area's very existence as a single administrative unit, when American plans in the Trust Territory were as vague as Micronesians' future intentions, there was little urgency about what has come to be known as the "future political status" of the Trust Territory. Yet with the passage of time, with the formation in 1961 of the Council of Micronesia, in 1965 of the Congress of Micronesia, and in 1967 of the Congress' Political Status Commission, we have reached our years of decision.

The Political Status Commission was created to study the alternatives before Micronesia and to make its recommendations to the Congress and to the people of Micronesia. We have not taken this task lightly nor have we accomplished our work quickly. Two years of study have gone into the recommendations we now make. We have consulted amongst ourselves. We have consulted scholars and administrators. We have weighed the interests of America and of our own people. Members of the Commission have travelled to the Virgin Islands, a territory of the United States, to Puerto Rico, a commonwealth of the Unired States, as well as to Washington.

Most recently, in order to learn what these islands could reasonably expect

This was the first official statement on the concept of free association and of the Congress of Micronesia's intent to pursue such a course. It was announced in 1969 by the Future Political Status Commission. 
or hope for it in the furure, the whole Commission visited island groups throughout the Pacific. We saw American Samoa, a territory of the United States, and Western Samoa, a former territory which has chosen independence. In Fiji we visited a crown colony of Britain. In Papua-New Guinea we toured the only other surviving Trust Territory in the world. Also, in our travels, we talked with leaders of Nauru, an independent island-nation, and the Cook Islands, a stare in free association with New Zealand. We believe that we have acquainted ourselves with every alternative we might possibly face; that we have studied and contemplated every reasonable political arrangement for Micronesia. After all our study and travel, after candid discussion with each other and deep personal thought, after having considered as many as a dozen political possibilities, we have reduced the desirable alternatives to two, and from among these two, we have chosen one.

To the Congress of Micronesia, to the district legislatures and municipal governments of Micronesia, to the Trust Territory administration and the Government of the United States, the Political Status Commission makes the following recommendation: that the Trust Territory of the Pacific Islands be constituted as a self-governing state and that this Micronesian state-internally self-governing and with Micronesian control of all its branches, including the executive-negotiate entry into free association with the United States.

In recommending that the Trust Territory become a free associated state, the Political Status Commission recognizes two inescapable realities: the need for Micronesian self-government and the fact of long-standing American interest in this area.

We choose a free state because the continuation of a quasi-colonial status would prove degrading to Micronesia and unworthy of America. Difficulties and problems will surely arise, but the administering authority in these islands must become an authority administered by Micronesians. At the same time, we choose an associated state because we recognize the historically unique partnership between Micronesia and the United States. In recommending free association with the United States, we seek not an end but a re-definition, renewal and improvement of this partnership.

Whatever our particular evaluations of the American administration in Micronesia may be, we feel that one contribution has been indelible, one achievement almost unqualified: the idea of democratic, representative, constitutional government. Our recommendation of a free associated state is indissolubly linked to our desire for such a democratic, representative, constitutional government. We endorse this system-which was brought to us by America and which we have come to know as an essentially American system.

Yet our partnership with the United States and our endorsement of the American democratic system must be joined by our wish to live as Micronesians, to maintain our Micronesian identity, to create a Micronesian state. Such a state, we believe, would be a credit to America and to ourselves. As a self-governing state in free association with the United States, our past twenty 
years of partnership would be raised to a new level in a compact, not between guardian and ward, but between more nearly equal friends.

Now we must ask, as others will ask, what can a self-governing Micronesian state hope for from its free association with the United States? And what can the United States expect from Micronesia? As a self-governing state, Micronesia will continue to look to America: for representation and protection in international affairs, for material and human assistance in the affairs of government, both in times of crisis and in day-to-day operations. As a self-governing stare, Micronesia's needs will be as great or greater than as a Territory. We do not underestimate the problems we will face. We do not wish for any lessening of American concern for Micronesia or of American presence in Micronesia.

How, then, will America benefit by entering into association with Micronesia? How can Micronesia hope to reward continued American contributions to its development? We would point out-without the slightest suggestion of self-righteousness-that there was an element of trust, of moral obligation, involved when the United States undertook responsibility for these islands, and that such an obligarion, which was begun when these islands were in ruins, should not be ended when they are reaching for political maturity.

Yet there is one item of material value which Micronesians can offer the United States-an item which is most precious in Micronesia and to Micronesians: the use of their land. Micronesians recognize that their islands are of strategic value, that the United States may require the use of some areas for purposes of military training and defense. We have seen the strategic value of these islands, have seen them conquered in historic battles, have seen them used for nuclear experiments and missile testing. Our experience with the military has not always been encouraging. But as a self-governing state in free association with the United States, we would accept the necessity of such military needs and we would feel confident that we could enter into responsible negotiations with the military, endeavoring to meet American requirements while protecting our own interests.

Relinquishing use of land, accepting the presence of large numbers of military personnel, accepting the risk of treatment as a target area by a hostile power in war are not conditions to be lightly undertaken. But as a self-governing state we would be far more prepared to face these prospects than as a Trust Territory.

Thus, with a sense of the profound responsibilities upon all concerned, the Political Status Commission repeats its recommendation that Micronesia be constituted as a self-governing state in free association with the United States.

To turn this recommendation into reality, we must face long and complex negotiations. The United States may be called upon to make unprecedented provisions and accommodations, but we are confident that they will meet with us openly and in good faith. From the time it acquired territories in the Louisiana Purchase of 1803 , through the settlement of the continental United 


\section{Appendix 2}

States, the acquisition of Alaska and Hawaii, Puerto Rico and other island areas the United States has dealt flexibly and imaginatively with its territories. It ha: shown a willingness to evaluate each territory as a separate case-anc Micronesia surely is that.

For ourselves, we look forward to the success of furure negotiations with the United States. But if these negotiations should fail, if it should not be possible to achieve the alternative we recommend, then we have only one remaining course. It is the second alternative mentioned in the Trusteeship Agreement, an alternative which might bring economic hardship and administrative difficulties. That alternative is independence. Independence is not the alternative we now recommend, but if it should prove impossible to renew our partnership with the United States as an associated free state, the Political Status Commission feels that independence would be the only road left open to us.

In the times to come, we will look to the United States for friendship and aid; but, wharever our relationship with the United States, whether as an independent nation or an associated free state, we must also look to Micronesians, look to ourselves. We maintain that the basic ownership of these islands rests with Micronesians and so does the basic responsibility for governing them. 


\section{Jurisdictional Boundaries and \\ Appendix 3. Political Leanings of the Six \\ Districts of Micronesia}




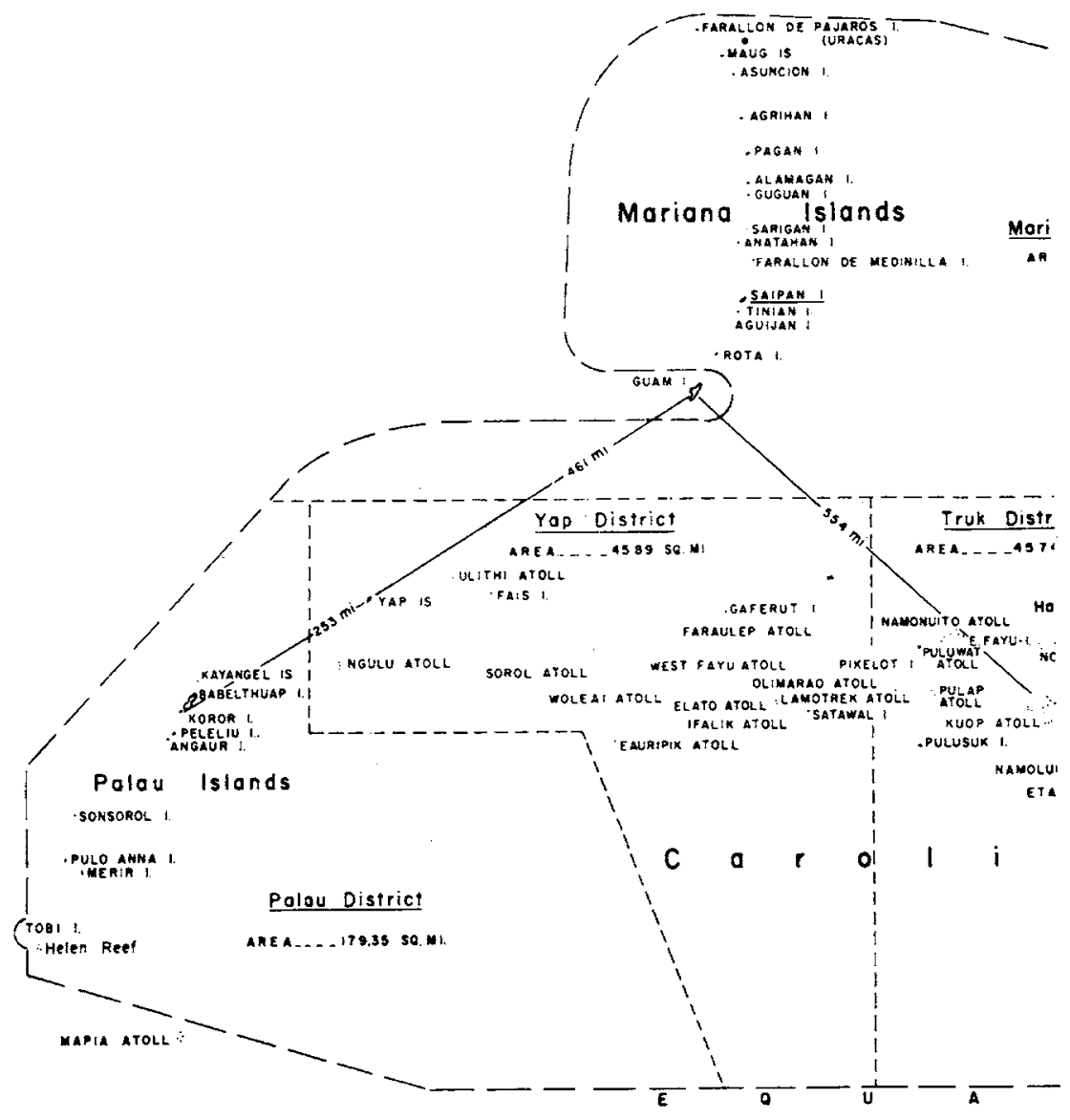

POLITICAL LEANINGS OF THE SIX DISTRICTS

Mariana Islands District: Complete integration with the United States; now conducting separate negotiations with the United States

Yap District: Leaning toward free association

Palau District: Leaning toward free association; may consider separate status

Truk District: Seat of independence movement; segment of Truk leaning toward free association

Ponape District: Leaning toward free association

Marshall Islands District: Legislature has opted for separate negotiations; large segment leaning toward free association 


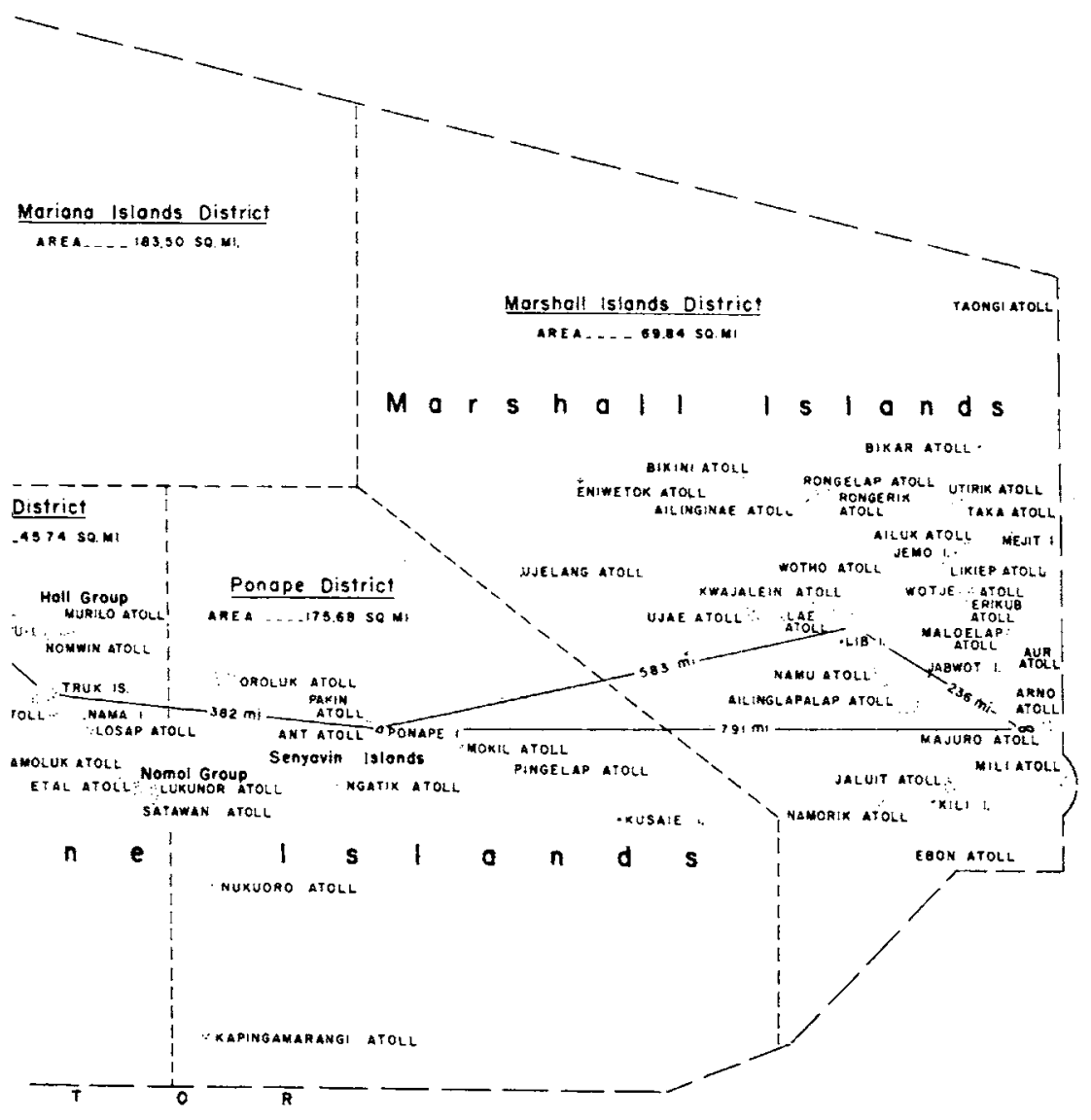




\section{Appendix 4. \\ Text of the Trusteesbip Agree- ment for the Trust Territory of the Pacific lslands}

PREAMBLE

Whereas Article 75 of the Charter of the United Nations provides for the establishment of an international trusteeship system for the administration and supervision of such territories as may be placed thereunder by subsequent agreements; and

Whereas under Article 77 of the said Charter the trusteeship system may be applied to territories now held under mandate; and

Whereas on 17 December 1920 the Council of the League of Nations confirmed a mandate for the former German islands north of the equator to Japan, to be administered in accordance with Article 22 of the Covenant of the League of Nations; and

Whereas Japan, as a result of the Second World War, has ceased to exercise any authority in these islands;

Now, therefore, the Security Council of the United Nations, having satisfied itself that the relevant articles of the Charter have been complied with, hereby resolves to approve the following terms of trusteeship for the Pacific Islands formerly under mandate to Japan.

Article 1. The Territory of the Pacific Islands, consisting of the islands formerly held by Japan under mandate in accordance with Article 22 of the Covenant of the League of Nations, is hereby designated as a strategic area and placed under the trusteeship system established in the Charter of the United Nations. The Territory of the Pacific Islands is hereinafter referred to as the trust territory.

Article 2. The United States of America is designated as the administering authority of the trust territory.

Article 3 . The administering authority shall have full powers of administra- 
tion, legislation, and jurisdiction over the territory subject to the provisions of this agreement, and may apply to the trust territory, subject to any modifications which the administering authority may consider desirable, such of the laws of the United States as it may deem appropriate to local conditions and requirements.

Article 4. The administering authority, in discharging the obligations of trusteeship in the trust territory, shall act in accordance with the Charter of the United Nations, and the provisions of this agreement, and shall, as specified in Article 83 (2) of the Charter, apply the objectives of the international trusteeship system, as set forth in Article 76 of the Charter, to the people of the trust territory.

Article 5. In discharging its obligations under Arricle 76 (a) and Article 84 of the Charter, the administering authority shall ensure that the trust territory shall play its part, in accordance with the Charter of the United Nations, in the maintenance of international peace and security. To this end the administering authority shall be entitled:

1. to establish naval, military and air bases and to erect fortifications in the trust territory;

2. to station and employ armed forces in the territory; and

3. to make use of volunteer forces, facilities and assistance from the trust territory in carrying our the obligations towards the Security Council undertaken in this regard by the administering authority, as well as for the local defense and the maintenance of law and order within the trust territory.

Article 6. In discharging its obligations under Article 76 (b) of the Charter, the administering authority shall:

1. foster the development of such political instirutions as are suited to the trust territory and shall promote the development of the inhabitants of the trust territory toward self-government or independence as may be appropriate to the particular circumstances of the trust territory and its peoples and the freely expressed wishes of the peoples concerned; and to this end shall give to the inhabitants of the trust territory a progressively increasing share in the administrative services in the territory; shall develop their participation in government; shall give due recognition to the customs of the inhabitants in providing a system of law for the territory; and shall take other appropriate measures toward these ends;

2. promote the economic advancement and self-sufficiency of the inhabitants, and to this end shall regulare the use of natural resources; encourage the development of fisheries, agriculture, and industries; protect the inhabitants against the loss of their lands and resources; and improve the means of transportation and communication;

3. promote the social advancement of the inhabitants and to this end shall protect the rights and fundamental freedoms of all elements of the population without discrimination; protect the health of the inhabitants; control the traffic 
in arms and ammunition, opium and other dangerous drugs, and alcohol and other spirituous beverages; and to institute such other regulations as may be necessary to protect the inhabitants against social abuses; and

4. promote the educational advancement of the inhabitants, and to this end shall take steps toward the establishment of a general system of elementary education; facilitate the vocational and cultural advancement of the population; and shall encourage qualified students to pursue higher education, including training on the professional level.

Article 7. In discharging its obligations under Article 76 (a) of the Charter, the administering authority shall guarantee to the inhabitants of the trust territory freedom of conscience, and, subject only to the requirements of public order and security, freedom of speech, of the press, and of assembly; freedom of worship, and of religious teaching; and freedom of migration and movement.

Article 8. 1. In discharging its obligations under Article 76 (d) of the Charter, as defined by Article 83 (2) of the Charter, the administering authority, subject to the requirements of security, and the obligation to promote the advancement of the inhabitants, shall accord to nationals of each Member of the United Nations and to companies and associations organized in conformity with the laws of such Member, treatment in the trust territory no less favourable than that accorded therein to nationals, companies and associations of any other United Nation except the administering authority.

2. The administering authority shall ensure equal treatment to the Members of the Unired Nations and their nationals in the administration of justice.

3. Nothing in the Article shall be construed as to accord traffic rights to aircraft flying into and out of the trust territory. Such right shall be subject to agreement between the administering authority and the state whose nationality such aircraft possesses.

4. The administering authority may negotiate and conclude commercial and other treaties and agreements with Members of the United Nations and other states, designed to attain for the inhabitants of the trust territory treatment by the Members of the United Nations and other states no less favourable than that granted by them to the nationals of other states. The Security Council may recommend, or invite other organs of the United Nations to consider and recommend, what rights the inhabitants of the trust territory should acquire in consideration of the rights obtained by Members of the United Nations in the trust territory.

Article 9. The administering authority shall be entitled to constitute the trust territory into a customs, fiscal, or administrative union or federation with other territories under United States jurisdiction and to establish common services between such territories and the trust territory where such measures are not inconsistent with the basic objectives of the International Trusteeship System and with the terms of this agreement. 
Article 10. The administering authority, acting under the provisions of Article 3 of this agreement, may accept membership in any regional advisory commission, regional authority, or technical organization, or other voluntary association of states, may co-operate with specialized international bodies, public or private, and may engage in other forms of international co-operation.

Article 11.1 . The administering authority shall take the necessary steps to provide the status of citizenship of the trust territory for the inhabitants of the trust territory.

2. The administering authority shall afford diplomatic and consular protection to the inhabitants of the trust territory when outside the territorial limits of the trust territory or of the territory of the administering authority.

Article 12. The administering authority shall enact such legislation as may be necessary to place the provisions of this agreement in effect in the trust territory.

Article 13. The provisions of Articles 87 and 88 of the Charter shall be applicable to the trust territory, provided that the administering authority may determine the extent of their applicability to any areas which may from time to time be specified by it as closed for security reasons.

Article 14. The administering authority undertakes to apply in the trust territory the provisions of any international conventions and recommendations which may be appropriate to the particular circumstances of the trust territory and which would be conducive to the achievement of the basic objectives of Article 6 of this agreement.

Article 15. The terms of the present agreement shall not be altered, amended or terminated without the consent of the administering authority.

Article 16. The present agreement shall come into force when approved by the Security Council of the United Nations and by the Government of the United States after due constitutional process. 


\section{Bibliography}

\section{Books}

Alkire, William H. Lamotrek Atoll and Inter-Island Socioeconomic Ties. Urbana:

University of Illinois Press, 1965.

Barnet, Homer Garner. Palauan Society. Eugene: University of Oregon Publications, 1949.

- Being a Palauan. New York: Holt, Rinehart \& Winston, 1960. . Anthropology in Administration. Evanston: Row, Peterson and Co., 1956.

Barrau, Jacques. Subsistence Agriculture in Polynesia and Micronesia. Honolulu: Bishop Museum Press, 1961.

Bascom, William R. Pomape: A Pacific Economy in Transition. Berkeley and Los Angeles: University of California Press, 1965.

Bentzen, Conrad. Land and Livelihood on Mokil, an Atoll in the Eastern Carolines. 2 vols. Los Angeles: University of Southern California Press, 1949.

Bliss, Theodora Crosby. Micronesia: The American Board in the Island World. Boston: American Board of Commissioners for Foreign Missions, 1906. Bohme, Hans Heinrich. Der Ahnenkult in Mikronesien [Ancestor Worship in Micronesia]. In Studien zur Religionswiss, vol. 2. Leipzig, 1937.

Bowers, Neal M. Problems of Resettlement on Saipan, Tinian and Rota, Mariana Islands. Published: CIMA Report no. 31. Pacific Science Board, 1957.

Buck, Peter H. Material Culture of Kapingamarangi. Honolulu: Bishop Museum Press, 1950.

Casagrande, Joseph B., ed. In the Company of Man. New York: Harper \& Row, 1960. 
Christian, F. W. The Caroline Islands. London: Methuen \& Co., 1899; new impression, 1967.

Crowl, Philip A. Campaign in the Marianas: The War in the Pacific. Washington, D.C.: Department of the Army, 1960.

Damon, Samuel C. "Morning Star" Papers. (Glimpses and glances at the sights, scenes and people of Micronesia.) Supplement to The Friend. Honolulu: Hawaiian Missionary Society Press, 1861.

DeSmith, Stanley A. Microstates and Micronesia: Problems of America's Pacific Islands. New York: New York University Press, 1970.

Emory, Kenneth P. Kapingamarangi: Social and Religious Life of a Polynesian Atoll. Honolulu: Bishop Museum Press, 1965.

Force, Roland W. Leadership and Culural Change in Palau. Chicago: Natural History Museum, 1960.

Gladwin, Thomas, and Seymour B. Sarason. Truk: Man in Paradise. Chicago: Johnson Publishing Co., 1953.

Goodenough, Ward H. Property, Kin and Community on Truk. New Haven: Yale University Press, 1951.

Gulick, L. H. Lectures on Micronesia. Hawaiian Historical Society. 52nd Annual Report, pp. 7-55. Honolulu: Hawaiian Historical Society, 1943.

Hasebe, K., and Ichiro Yawata. The South Sea Islands in the Past. In Japanese. Tokyo: Oka Shoin, 1932.

Henning, Theodore F. Buritis in Paradise. New York: Greenwich Book Publishers, 1961.

Hough, Frank O. The Island War: The United States Marine Corps in the Pacific. Philadelphia and New York: J. B. Lippincott Co., 1947.

Joseph, Alice, and Veronica F. Murray. Chamorros and Carolinians of Saipan. Cambridge: Harvard University Press, 1951.

Kahn, E. J., Jr. A Reporter in Micronesia. New York: W. W. Norton \& Co., 1966.

Karig, Walter. The Fortunate Islands: A Pacific Interlude. New York: Holt, Rinehart \& Winston, 1948.

Koskinen, Aarne. Missiomary Infuence as a Political Factor in the Pacific Islands. Helsinki: Finnish Academy of Science, 1963.

Krieger, Herbert W. Island Peoples of the Western Pacific: Micronesia and Melanesia. Washington, D.C.: Smithsonian Institution Press, 1943.

Le Bar, Frank M. The Material Culture of Truk. New Haven: Yale University Press, 1964.

Lessa, William A. Ulithi: A Micronesian Design for Living. New York: Holt, Rinehart \& Winston, 1966.

Linton, Ralph. Ethnology of Polynesia and Micronesia. Chicago: Field Museum of Natural History, 1926. 
McCarthy, Eugene J. The Limits of Power: America's Role in the World. New York: Holt, Rinehart \& Winston, 1967.

Meller, Norman. The Congress of Micromesia. Honolulu: University of Hawaii Press, 1969.

Oliver, Douglas L. The Pacific Islands. New York: Doubleday \& Co., 1951.

- Planning Micronesia's Future: A Summary of the U.S. Commercial Company's Economic Survey of Micronesia. Honolulu: University of Hawaii Press, 1971.

Parkins, Whitney T. Denial of Empire: The U.S. and Its Dependencies. Leyden, Netherlands: A. W. Sythoff, 1962.

Price, Willard. America's Paradise Lost: The Strange Story of the Secret Atolls. New York: John Day, 1966.

—. Pacific Adventure. New York: Day Reynal \& Hitchcock, 1936.

- South Sea Adventure. New York: G. P. Putnam's Sons, 1952.

Richards, Dorothy E. U.S. Naval Administration of the Trust Territory of the Pacific Islands. 3 vols. Washington, D.C.: Office, Chief of Naval Operations, 1957.

Sandelmann, John. Some Observations on the Problem of Self-Government in the Trust Territory of the Pacific Islands. Honolulu: Trust Territory Government, 1953.

Spoehr, Alexander. Saipan: The Ethnology of a War-Devastated Island. Chicago: Natural History Museum, 1954.

Schlesier, Erhard. Die Erscheinungs formen des Mannerhauses und das Klubwesen in Mikronesien [The Characteristic Forms Taken by Houses for Males and the Nature of Club Life in Micronesia]. The Hague: Mouton, 1953.

Stillfried, Bernard. Die soziale Organisation in Mikromesien [Social Organization in Micronesia]. Vienna: Institut für Völkerkunde, University of Vienna, 1953.

Tetens, Alfred. Among the Savages of the South Seas: Memoirs of Micronesia, 1862-1868. Translated by Florence Mann Spoehr. Stanford: Stanford University Press, 1958.

Toomin, Philip R., and Pauline M. Toomin. Black Robe and Grass Skirt. New York: Horizon Press, 1963.

Trumbull, Robert. Paradise in Trust. New York: William Sloan Associates, 1959.

Vidich, A. J. Political Factionalism in Palau: Its Rise and Development. CIMA Final Report no. 23. Pacific Science Board, 1949.

Weinhouse, David M. Remnants of Empire: The United Nations and the End of Colonialism. New York: Harper \& Row, published for the Council on Foreign Relations, 1964. 
Weins, Harold J. Pacific Islands Bastions of the United States. New York: Van Nostrand Reinhold Co., 1962.

Yanaihara, Tadao. Parific Islands under Japanese Mandate. New York: Oxford University Press, 1940.

\section{Articles}

Arnold, Edwin G. "Self-Government in U.S. Territories." Foreign Affairs (July 1947): 655-666.

Bascom, William. "Ponapean Prestige Economy." Southwestern Journal of Anthropology 4(2):211-221.

Bergbauer, Harry W., Jr. "A Review of the Political Status of the Trust Territory of the Pacific." Naval War College Review 22(7):43-51.

Blaz, Vicente T., and Samuel S. H. Lee. "The Cross of Micronesia." Naval War College Review 23(10):59-89.

Bodley, R. V. C. "My Wanderings in Unknown Micronesia." Wide World Magazine 75 (June 1935):124-130.

Dobbs, James C. "A Macrostudy of Micronesia: The Ending of a Trusteeship." New York Law Fonum 18(1972):139-215.

Duke, Marvin L. "Micronesia: Western Line of Defense." Marine Corps Gazette 53(10):39-42.

Embree, J. F. "Micronesia: The Navy and Democracy." Far Eastern Survey 15(1946):161-164.

Fite, Jerry. "Colonizing Paradise." The Washington Monthly (1971):56-58.

Freeman, Harrop. "Micronesia and the United States: A Legal Discussion."

Mimeographed. 1971. Congress of Micronesia Library, Saipan, Mariana Islands.

Gillchrist, H. "Dependent Peoples and Mandates." Pioneer in World Order. New York: Columbia University Press, 1944.

—. "The Japanese Islands: Annexarion or Trusteeship?" Foreign Affairs (July 1944):635-642.

Gladwin, Thomas. "Micronesian Independence: The Essential Elements." Mimeographed. 1971. Congress of Micronesia Library, Saipan, Mariana Islands.

Gulick, L. H. "Micronesia of the Pacific Ocean." Nautical Magazine and Naval Chronicle 31(1862):169-182, 237-245, 298-308, 359-363, 408-417.

Heine, Carl. "Micronesia Is Confused about What It Wants." Pacific Islands Monthly (September 1970):18-19.

Hitch, Thomas K. "Administration of America's Pacific Islands." Political Science Quarterly 61(September 1946):384-407.

Jacobson, Harold Karen. "Our Colonial Problems in the Pacific." Foreign Affairs (October 1960):56-66. 
Johnson, Donald D. "The Trust Territory of the Pacific Islands." Current History 58(April 1970):233-239.

Johnston, William J. "The United States as a Pacific Power." Current History 58(344): 193-195.

Kahn, E. J., Jr. "The Small Islands: America and Its Responsibility." Saturday Review (October 1966):40-45.

Keesing, Felix M. "Former Japanese Mandated Islands." Far Eastern Survey 14(1945):269-271.

Kluge, P. F. "Micronesia: America's Troubled Pacific Ward." Reader's Digest (December 1971):161-164.

Lindley, Ernest K. "Trusteeship or Annexation?" Newsweek 27(February 1946):16-17.

Lyman, Richard, Jr. "Report on the Marshalls, Carolines and Marianas." U.S. Commercial Company Economic Survey of Micronesia. No. 16, 1946.

Mason, L. "An Interpretation of Native Custom in a Changing Oceanic Society." 7th Pacific Science Congress Proceedings (1953):95-102.

Meller, Norman. "Indigenous Leadership in the Trust Territory of the Pacific Islands." In Development Administration in Asia. Edited by Edward W. Wiedner. Durharn: Duke University Press, 1970.

Midkiff, F. E. "Administering the Pacific Trust Territory." U.S. Department of State Bulletin 29 (1953):150-157.

- "Problems in the Administration of the Pacific Trust Territory." U.S. Department of State Bulletin 29 (1953):22-26.

—. "Problems of the Pacific Trust." U.S. Department of State Bulletin 31 (1954):141-145.

- "U.S. Administration of the Trust Territory of the Pacific Islands." U.S. Department of State Bulletin 31 (1954):96-109.

Mihaly, Eugene B. "U.S. Strategy in the Western Pacific and the Micronesia Dilemma." Mimeographed. Berkeley: Institure of International Studies, University of California, 1971.

. "Micronesia's Furure and the Changing American Role in the Pacific." Mimeographed. Berkeley: Institute of International Studies, University of California, 1971.

Miller, William O. "The United Nations and Oceania: New Dimensions in the Cold War Refrain." Naval War College Review 21(10):45-59.

Mink, Patsy T. "Micronesia: Our Bungled Trust." Texas International Law Forum 6(2):181-207.

Morgiewicz, Daniel J. "Micronesia: Especial Trust." U.S. Naval Institute Proceedings 94(10):68-79.

Murphy, Raymond E. "Land Ownership on a Micronesian Atoll." Geographical Review 38(4):598-614. 
Pomeroy, E. S. "American Policy Respecting the Marshalls, Carolines and Marianas 1898-1941." Pacific Historical Review 17(1948):43-53.

Powells, Guy. "Political Alternatives in Micronesia." Pacific Affairs 43(1):8490.

Quigg, Philip W. "Coming of Age in Micronesia." Foreign Affairs (April 1969):493-508.

Riley, Frank. "Storm over Micronesia." Saturday Review (September 1969):56ff.

Roucek, Joseph S. "The Pacific in Geopolitics." Contemporary Review 206 (1189):63-76.

Sayre, F. B. "Trust Territories' Progress towards Self-Government." U.S. - Department of State Bulletin 25 (1951):1024-1027.

Smith, A. H. "Attitudes and Relationships (American-Micronesia)." Micronesian Monthly 4(1):26-31.

Tauber, I. B., and C. H. Chungim. "Micronesian Islands under U.S. Trusteeship." Demographic Paradox (1950):93-115.

Taylor, J. A. "The Role of American-Micronesia as a Strategic Trusteeship." (Photocopied.) March 1965.

Useem, John. "Governing the Occupied Areas of the South Pacific: Wartime Lessons and Peacetime Proposals." Applied Anthropology 4(3):1-10.

. "Changing Structure of a Micronesian Society." American Anthropologist 47(1945):567-588.

\section{United States Government Documents}

Amending the Act of June 30,1954, as amended, providing for the continuance of civil government for the Trust Territory of the Pacific Islands. Congressional Record, March 21, 1967, pp. H3091-H3102.

"Basic Instruments for the Governance of the Trust Territory of the Pacific Islands." Mimeographed. 27 pp. Political Affairs Office, Trust Territory of the Pacific Islands. Congress of Micronesia Library, Saipan, Mariana Islands.

"Council of Micronesia." Congressional Record, August 26, 1966, pp. 1997319975.

"Council of Micronesia." In Proceedings, 4th Session, Saipan, M.1., 1963, pp. 37-43. Congress of Micronesia Library, Saipan, Mariana Islands.

"The Future Political Status." A Report by President Nixon's Personal Representative to Micronesian Status Negotiations at Hana, Maui, Hawaii, 1971. Washington, D.C.: Office of Micronesian Status Negotiations, 1971.

"The Future Political Status of Micronesia." Congressiomal Record, June 15, 1967, pp. S8287-S8289. 
"Micronesia." Legislative Reference Service, Library of Congress, Washington, D.C. 14 pp. Photocopied.

"Micronesia: The Forgotten Islands." Congressional Record, November 9, 1967, pp. Hi5028-Hi5030.

"Present and Future Status of Trusteeship for the Mariana, Caroline and Marshall Islands," Legislative Reference Service, Library of Congress, Washington, D.C. 6 pp. Photocopied.

"The Trust Territory Looks to the Future: Union or Independence?" Congressional Record, June 16, 1966, pp. 12863-12872.

\section{Congress of Micronesta Government Documents}

All materials listed in this section were published by the Trust Territory Government Printing Office, and may be obtained from the Library of the Congress of Micronesia, Saipan, Mariana Islands.

Draft Compact of Free Association: Report, The Fifth Round of Talks in Washingtom, D.C. Congress of Micronesia, Saipan, Mariana Islands, August 1972.

The Future Political Status Commission, Interim Report. Congress of Micronesia, Saipan, Mariana Islands, July 8, 1968.

The Future Political Status Commission, Report. Congress of Micronesia, Saipan, Mariana Islands, July 1970.

The Future Political Status of Micromesia: Proceedings of the Sixth Round of Talks at Barbers Point, Honolulu, Hawaii. Congress of Micronesia, Saipan, Mariana Islands, November 1972.

The Joint Committee on Future Status, Report. Congress of Micronesia, Saipan, Mariana Islands, April 1972.

The Joint Committee on Future Status, Draft Report. Congress of Micronesia, Saipan, Mariana Islands, December 1971.

Micromesia: A New Frontier. A Special Report to the Congress of Micromesia, Special Session, Ponape. Congress of Micronesia Library, Saipan, Mariana Islands, 1972.

Political Modernization of Micronesia. A symposium. Center for South Pacific Studies, University of California, Santa Cruz, California, 1969.

The Political Status Delegation, Report. Congress of Micronesia, Saipan, Mariana Islands, July 1970.

Political Status Digest. Congress of Micronesia, Saipan, Mariana Islands, August 1970.

Political Status Digest. Congress of Micronesia, Saipan, Mariana Islands, August 1971.

Public Speeches. Congress of Micronesia, Saipan, Mariana İslands, December 20, 1968. 
Public Speeches. Congress of Micronesia, Saipan, Mariana Islands, December 1971.

Special Sub-Committee of the Joint Committee on Future Status, Report. Congress of Micronesia, Saipan, Mariana Islands, January 1972.

\section{UnPUBLISHEd Materials}

Alkire, William Henry. "Residence, Economy and Habitat in the Caroline Islands: A Study in Ecologic Adaption." Master's thesis, University of Hawaii, 1959.

Antrila, E. K. "A History of the People of the Trust Territory of the Pacific Islands and Their Education." Ph.D. thesis, University of Texas, 1965.

Bayard, D. T. "The Cultural Relationships of the Polynesian Ourliers." Master's thesis, University of Hawaii, 1966.

Beardsley, J. W. "The Coccoidea of Micronesia (Homoptera)." Ph.D. thesis, University of Hawaii, 1963.

Bender, Byron Wilbur. "A Linguistic Analysis of the Place-Names of the Marshall Islands." Ph.D. thesis, Indiana University, 1963.

Bradley, William Paul. "The History of the Marianas, Carolines, Pelew and Marshall Islands to the Year 1922." Master's thesis, University of Southern California, 1937.

Brown, Carroll. "A Survey of United States Administration of the Trust Territory of the Pacific Islands." Master's thesis, Columbia University, 1953.

Carroll, Vern. "Nukuoro Kinship." Ph.D. thesis, Universiry of Chicago, 1966. Caughey, John. "Culture Values in a Micronesian Society." Ph.D. thesis, University of Pennsylvania, 1970.

Chapman, Peter Sherwood. "Micronesian Archaeology: An Annorated Bibliography." Master's thesis, Stanford University, 1964.

Chave, Margaret Elinor. "The Changing Position of the Mixed-Bloods in the Marshall Islands." Master's thesis, University of Indiana, 1963.

Clark, Donald Hugh. "Pacific Islands under Japanese Mandate." Master's thesis, Columbia University, 1935.

Coale, George L. "A Study of Chieftainship, Missionary Contact and Culture Change on Ponape, 1852-1900." Master's thesis, University of Southern California, 1951.

Cockrum, E. E., "The Emergence of Modern Micronesia." Ph.D. thesis, University of Colorado, 1970.

Cohen, Herbert. "Class and Land in Micronesia." Master's thesis, University of Chicago, 1952. 
Collister, Louis J. "Trust Territory of the Pacific Islands-Problems or Opportunity?" Research paper, U.S. Army War College, 1964.

Cox, Samuel Allen. "An Analysis of Geographical Influences on Micronesian Culture." Master's thesis, West Chester State College, 1970.

Eckert, Georg. "Der Einfluss des Geschlects- und Familienlebens auf die Bevölkerungs- Bewegung mikronesischer Inseln" [The Influence of Sex and Family Life on the Movements of the People of the Micronesian Islands]. Ph.D. thesis, University of Bonn, 1935.

Emerick, Richard G. "Homesteading on Ponape: A Study and Analysis of a

Resettlement Program of the United States Trust Territory Government in Micronesia." Ph.D. thesis, University of Pennsylvania, 1960.

Fink, T. Ross. "United States Naval Policies on Education in Dependent Areas." Ph.D. thesis, University of North Carolina, 1948.

Fischer, Ann M. "The Role of the Trukese Mother and Its Effect on Child Training." Ph.D. thesis, Radcliffe College, 1957.

Fischer, John L. "Language and Folktale in Truk and Ponape: A Study in Cultural Integration." Ph.D. thesis, Harvard University, 1954.

Fukuzawa, En-Ichi. "The Question of Sovereignty in Relation to Japan's Mandate of the South Pacific Islands." Master's thesis, Columbia University, 1935.

Gladwin, Thomas. "Personality and Development on Truk." Ph. D. thesis, Harvard University, 1952.

Gooding, Niles Russell. "The Administration of the Trust Territory of the Pacific Islands, 1945-1962." Master's thesis, The American University, 1962.

Grahlfs, Francis L., Jr. "The Effects of Japanese Occupation in Micronesia." Master's thesis, Columbia University, 1955.

Hainline, Lydia Jane. "Human Ecology in Micronesia: Determinants of Population Size, Structure and Dynamics." Ph.D. thesis, University of California, 1964.

Heine, Carl. "A Historical Study of Political Development and the Prospect for Self-government in the United States Pacific Trust Territory." Bachelor's thesis, Pacific University, 1965.

Holbrook, F. X., "United States Naval Defense and Trans-Pacific Commercial Air Routes 1933-1941." Ph.D. thesis, Fordham University, 1969.

Hunt, Edward E., Jr. "Studies of Physical Anthropology in Micronesia." Ph.D. thesis, Harvard University, 1951.

Jones, Garth Nelson. "Administration of the Trust Territory of the Pacific Islands." Ph.D. thesis, University of Utah, 1954.

Kiste, Robert Carl. "Changing Patterns of Land Tenure and Social Organiza- 
tion among the ex-Bikini Marshallese." Ph.D. thesis, University of Oregon, 1967.

Lang, Werner. "Steinbauten in Mikronesien" [Stone Buildings in Micronesia].

Ph.D. thesis, Georg-August University of Göttingen, 1951.

Lawrence, Julia F. "Food Supply in the Marshall Islands." Master's thesis, Yale University, 1943.

Lee, Rosalie Leong. "The American-Japanese Controversy over the Island of Yap." Master's thesis, University of Hawaii, 1939.

Lieber, M. D. "The Nature of the Relationship between Land Tenure and Kinship on Kapinga-Marangi Atoll." Ph.D. thesis, Pittsburgh University, 1968.

Logan-Smith, Nat. "A Descriptive Analysis of the Personnel Program for the Micronesian Employees of the Government of the Trust Territory of the Pacific Islands." Master's thesis, University of Hawaii, 1962.

McCracken, Ralph J. "Soil Geography of.Palau and Saipan." Master's thesis, Cornell University, 1951.

McKnight, Robert Kellogg. "Competition in Palau." Ph.D. thesis, Ohio State University, 1960.

Mahoney, Francis B. "Projective Psychological Findings in Palau Personality." Master's thesis, University of Chicago, 1950.

Mahony, F. J., "A Trukese Theory of Medicine." Ph.D. thesis, Stanford University, 1970.

Marine, George E. "Micronesia-United States Security Policy in East Asia and the Western Pacific." Research paper, The National War College, 1970.

Mason, Leonard. "Relocation of the Bikini Marshallese: A Study in Group Migration." Ph.D. thesis, Yale University, 1954.

May, Walther. "Die Erziehung in Mikronesien" [Education in Micronesia]. Ph.D. thesis, University of Bonn, 1957.

Milner, George. "Political Progress in Micronesia." Master's thesis, Princeton University, 1956.

Nason, James Duane. "Ecological Aspects of Cultural Stability and Culture Change in Micronesia." Master's thesis, University of Washington, 1967.

Newlon, Robert Edward. "Evolution of the United States' Position in Micronesia." Master's thesis, University of Chicago, 1949.

Oberem, Udo. "Die frühe Herrenkultur der mikronesischen Staaten (Ein Beitrag zum Wesen der Herrenkultur)" [The Ruling Class of the Early Civilization of the Micronesian States (A Contribution to the Nature of Upper-class Civilization)]. Ph.D. thesis, University of Bonn, 1951.

O'Connor, Edward C. "Micronesia-America's Western Frontier in the East." Master's thesis, George Washington University, 1969. 
Pierard, Richard Victor. "The German Colonial Society." Ph.D. thesis, State University of lowa, 1964.

Pollock, Nancy J. "Breadfruit and Breadwinning on Namu Atoll Marshall Islands." Ph.D. thesis, University of Hawaii, 1970.

Purcell, David Campbell, Jr., "Japanese Expansion in the South Pacific, 1890-1935." Ph.D. thesis, University of Pennsylvania, 1967.

Riesenberg, Saul Herbert. "The Cultural Position of Ponape in Oceania. Ph.D. thesis, University of California (Berkeley), 1950.

Robeson, Robert H. "Political/Military Necessity for United States-owned Naval Bases in the Western Pacific." Research paper, The National War College, 1970.

Sahir, Abul Hasan. "United States' Trust Territory in the Pacific Islands: A Potential Seastate." Master's thesis, University of Hawaii, 1966.

Saunders, Marion Grace. "Cross-cultural Study of Coalitions in the Triad." Master's thesis, University of Hawaii, 1960.

Schneider, David M. "The Kinship System and Village Organization of Yap, West Caroline Islands, Micronesia: A Structural and Functional Account." Ph.D. thesis, Harvard University, 1949.

Shahan, James Buhl. "American Colonial Administration in the Western Pacific: A Study in Civil-Military Relations." Ph.D. thesis, Ohio State University, 1950.

Sheridan, Francis P. "Why Strategic Areas? A Study of the Trusteeship Agreement for the Former Japanese Mandated Islands Administered by the United States of America." Master's thesis. Columbia University, 1954.

Solenberger, Robert R. "Chamorro-Carolinian Relations in the Marianas." Ph.D. thesis, University of Pennsylvania, 1966.

Stevens, Williarn D. "A Study of Depopulation on Yap Island." Ph.D. thesis, Harvard University, 1949.

Stone, Benjamin Clemens. "The Wild and Cultivated Pandanus of the Marshall Islands." Ph.D. thesis, University of Hawaii, 1960.

Stumpf, Margaret Katherine. "Palauan Value Orientation and Education." Ph.D. thesis, Teachers College, Columbia University, 1970.

Swartz, Marc Jerome. "The Social Organization of Behaviour: Relations among Kinsmen on Romonum, Truk." Ph.D. thesis, Harvard University, 1958. Thomas, Theodore Hubert. "The Aims, Organization of the Trust Territory of the Pacific Islands." Master's thesis, Duke University, 1957.

Tobin, J. A. "The Resetrlement of the Eniwetok People: A Study of a Displaced Community in the Marshall Islands." Ph.D. thesis, University of California (Berkeley), 1967.

Tol, Maynard J. "The Marshalls, Marianas, and Carolines under Germany, 
Japan, and the United States." Ph.D. thesis, School of Advanced International Studies, Johns Hopkins University, 1967.

Turner, G. B. "The Amphibious Complex: A Study of Operations at Saipan." Ph.D. thesis, Princeton University, 1950.

Vidich, A. J. "The Political Impact of Colonial Administration," Ph.D. thesis, Harvard Universiry, 1952.

Ward, William Theophilus Thomas. "A Preliminary Survey of the Economic and Social Life of the Mortlock Islands People, Eastern Carolines, Trust Territory of Micronesia." Master's thesis, University of Pennsylvania, 1968.

Wilson, Walter Scott. "Land Activity and Social Organization of Lelu, Kusaie." Ph.D. thesis, University of Pennsylvania, 1968.

Wyttenbach, Richard H. "Micronesia and Strategic Trusteeship: A Case Study in American Politico-Military Relations." Ph.D. thesis, Fletcher School of Law and Diplomacy, Tufts University, 1971.

Yamaguchi, Osamu. "The Music of Palau: An Ethnomusicological Study of the Classical Tradition." Master's thesis, University of Hawaii, 1967. 


\section{Index}

Acculturation process, 31-33

Agriculture, 21; program not advanced under United States, 56

Anthropologists, and Micronesians, 21,31

Bikini, 19; nuclear tests on, 19; returned to Bikinians in 1969,23

Budget for Micronesia, 146, 163, 168

Caroline Islands, 3

Chamorro, 12, 135

Christianity, $10,12,69,135$; as a unifying force, 25,26 ; as one of principal bases for social identification in rural areas, 34; conservatism of, 35; impact of, on traditional life, 24

Churches: Catholic, 24, 135; Protestant, 24, 135

Colonialism, 3, 159; American, 46, 141 ; earliest act of, 10 ; and its effects on Micronesia, 16; evils of, 49; consequences of, 35

Commercialization, 35-37, 136; awareness of Micronesians of need for, 36

Commonwealth status, offered by United States in $1970,126,147$

Communication network, 70

Confederation, of six districts of $\mathrm{Mi}$ cronesia, 75, 115, 116

Congress of Micronesia, $7,60,62,63$, $75-77,106,119,120,125,138,142$,
$146,159,173,175$; adoption of Senate Joint Resolution 25 by, 44; and posttrusteeship government, 73 ; as a breeding ground for Micronesian nationalism, 70 ; as the only authorized and legal spokesman of the people of Micronesia, 46; awareness of need to maintain cultural cohesion and unity, 77 ; beginnings in 1965 of the, 6, 44; effectiveness of the, as a unifying force, 112; effects of third round of talks at Hana, Maui, on the, 118; first requests of a greater measure of selfgovernment by the, 104; inability to provide national leadership at this time, 155; leadership needed in the, 121; meeting in Saipan in 1971, 127; power and authority of the, 85 ; present negotiations between Washington and the, 43 ; regionalism in the, 112; responsibility for the ultimate settlement of the political question to be made by the, 99; role in new status for Micronesia, 83; role in seeking the area's primary objectives, 21 ; sets forth in 1970 the four principles and legal rights of Micronesians, 46-48, 126,127 ; will oppose use of more land by the United States military, 59

Constitutional convention, 83, 84, 149,161 
Culture, 91, 98; desire to preserve their individual, 82 ; internal problems caused by variants in, 141 ; Micronesians' pride in their, 82

Davidson, J. W., 59, 169, 177

Decolonization, $44,45,56,57$; process of, 118, 134, 138, 139, 159, 168

Defense, strategic, of Micronesia, 150,153

Dilemma, 91, 93, 94, 120; caused by forces of modernization, 160 ; of average middle-class Micronesian, 135; political, 161, 162, 165, 169

Diplomatic relations, 100

Double standard, maintained by American administration in many areas, 56, 137

Economy, 91; basically that of subsistence, 27, 36; development of, 105; Micronesia's false, 167; money economy introduced by the Germans and Japanese, 28; products of island, 28; questions about the future development of Micronesia's, 165,166

Educated elite, 65, 82, 136; demands of, 136-137

Education, 21, 105, 136; as a status symbol, 27; program for collegelevel, 26, 27; spread of literacy under American system of public, 26; the revolutionary influence of American, 37, 38, 93; under the colonial powers, 93

English language: as a medium of communication, 110; as a vehicle for unity, 110

Ethnic diversity, 93; and consolidation of Micronesia, 121; distrust and dislike caused by, 111, 112; and fragmentation of Micronesian solidarity, 120; and isolation,. 114, 119

Executive branch of government, failure of United States to permit an, 85,86

Executive council, 139, 148

Federation, 113

Fifth Congress of Micronesia, 161, 162
Fragmentation, problems of, 53, 166, 167

Free association, $69,75,81-84,94$, $130,141,148,150,152,153$; as a balance between the status quo and independence, 80 ; as a choice, 157 , $158,161,165$; as a compact among friends, 80 ; as a temporary arrangement, 84 ; as beneficial to both the United States and Micronesia, 108, 109; as official position during discussions at Hana, Maui, 121; as proposed by the Congress of Micronesia's Future Political Status Commission, 79; favored by the Marshalls, Truk, Ponape, Yap, and Palau, 122; of Puerto Rico and the United States, and of Cook Islands and New Zealand, 79; one of the three alternatives open to Micronesians, 59; rejected at negotiations in 1970, 126; request for status of, 81 ; transition from selfgovernment to, 123

Freedom, 142; desire for, 74; love of, 80; pressure for greater social and economic and political, 43-46

Germany, 3, 62; administration by, 13, 16; development of copra trade by, 135; interest in trade and commercialization by, 135; period of Micronesia's domination by, 136; purchase of Spain's Pacific holdings by, 11

Geography, 69, 70, 91, 102, 115, 139; operational problems caused by, 70 ; the curse of, 167

Gradualism policy, as a policy of neglect by the United States, 56

Hana, Maui, Hawaii, negotiations at, $8,118,127,128,147$

Health, 21, 105

Ignorance, 38, 156

Illiteracy, 38,149

Independence, $81,82,86,96,140,150$, $152,154,156,157-159,175$; as a crucial point in the evolution of any dependent peoples, 53-54; as a goal of Trukese, 127; as a way out of colonization, 51 ; can Micronesia attain, 97; economic weak- 
ness of Micronesia crucial to its, 97; high costs of, 99, 100, 102; is Micronesia ready for, 97 ; one of three major alternatives open to Micronesia, 59, 69, 74; should Micronesia have, 97, 98-100

Innovators, 63,64 ; as opponents of the status quo, 64; as the changeseeking elite, 67; revolutionary character of, 64; within the younger generation, 66

Integration with a major power, one of the three major alternatives open to Micronesia, 59, 86

Interior, Department of the, $5,6,58$, $60,61,147,154,167$

International trusteeship: agreement signed, 15 ; formation of, $4,5,15$; new negotiations on, 5; problems in formation of, 4,5

Jaluit Company, role in German administration of Marshall Islands, 13

Japan, 3, 5, 6; as a model for future Micronesian way of life, 69 ; colonial policy of, 14, 16, 63; establishment of trade schools by, 26; influx of settlers from, 14; integration attempts by, 135; occupation of Micronesia by, 14; period of domination by, 136

Joint Committee on Future Status, $59,68,108,138,153,154,162,168$, 171,176 ; as a representative of Micronesia, 44; goals of the, 113, 114; presentation of eleven points at first negotiations by, 125 ; proposal of free association by the, 79, Senator Lazarus E. Salii as creator of, 58; terms of general accord reached by United States in 1972 with, 131

Judicial system, 74 ; the creation of the semi-independent, 85; under the National Council System, 77; under the presidential system, 76; under the Westminster system, 77

Land: and land-lease systems, 142; buying and leasing of, 93; for military purposes, 59; in Palau, 133; Micronesians' control over their, 126,151

Leaders: alienation of followers from, 120 ; crying need for, 119 ; in the Congress of Micronesia, 121; quest for political status of, 120

League of Nations, 14; mandate system of, 16; view of separatism in Micronesia of, 174

Legislative branch, $85,121,159$; advisory bodies of, 7 ; as "clubs," 71

Liberalism, as a force opposed to conservatism, 26, 27

Linguistic problems, 21, 49, 92, 110; due to various loyalties, 70,111 ; need to overcome, 74

\section{Manpower training, 21}

Mariana Islands, 3, 50, 53; desire of the Rotanese to secede from the, 120; desire to join with Guam, 53, 172, District Legislature, 7; embracement of United States militarism, 53; influx of Japanese into, 14; united and ready to accept the idea of separate status with the United States, 127, 132, 151; strong Spanish influence in the, 12,135

Marshall Islands, 3; Congress, 7; contact among the people of the, 112; Jaluit Company's role during German administration in, 13; majority favors free association, 122; new political events in, 171,172 , 174

Micronesia: administration by the United States, 15-17; as an essentially Christian country, 34 ; as a very tradition-oriented society, 25 ; area of, 3, 4; choices of ultimate destiny, 22, 74; communication network and transportation problems, 69, 70; composition of, 3, 4; confusion of goals and directions at present in, 122, 148; decolonization of, 8; development of local government units in, 6 ; distorted view by the rest of the world of, 19; domination by Germany, 13, 14; domination by Spain, 10-13; economic resources of, 4 ; false economy in, 167; introduction of Western institutions in, 21; Japanese era, 5, 6; judicial system in, 74; legal rights of the five districts of, 53 ; needs in health, education, agriculture, and manpower train- 
ing in, 21; occupation by Japan, 14 ; present-day paternalistic attitudes toward, 62; problems of governing such a large area as, 69; problems of outer islands of, 87, 88; powers of, under free association, 150; relationship with the United States and United Nations at present, 55; viewed as a static society by Western civilization, 30 ; weak resources of, 4 ; work of the early missionaries in, 24

Micronesians: advantages of "planning-for" approach for, 63, 64; apathy of great majority of, 164; concept of democracy and alien rule, 8; confused view of reality of, 169; desire for imported goods to augment subsistence economy, 28; disadvantages of "planning-for" approach for, 63, 64; early carefree life and later submission to domination, 20; first awareness of their geographical relationships, 25; growing awareness of need for conmercialization, 36; historical isolation of, 8 ; influence of modernization on individual, 31; lack of feeling of unity among the, 111-116; majority do not want to sever present relationship with United States, 49; must declare the kind of life-style they prefer, 68; philosophical confusion due to varying colonial rulers among the, 20 ; present problems besetting the, 21,148 ; problems with new experience of democracy, 20 ; resentment of decisions made in Washington without consultations with, 62,142 ; role of educated and Westernized elite among, 32; seek to regain their own destiny, 17; sense of dignity, 88; spread of Christianity among, 24

Mini-states, 49, 52

Military, 59; acquisition of use-right land, 56; as the main interest of the United States in Micronesia, 105 ; buying and leasing of lands by the, 93 ; erection of fortifications by the, 56; troops in Micronesia, 150; use in the Marshall Islands, 172; use of the islands of
Palau, 133; withdrawal from the Pacific, 144, 145

Modernization, 22, 32, 35, 66, 91-93, 95,98

National council system, 77

National goals, 122; confusion regarding, 122; lack of, 122

Nationalism, 74, 81, 82, 140, 158, 159

National unity, $155-157,160,162$; or fragmentation, 166, 167

Natural resources, lack of, 21,141

Negotiations: Barbers Point, Hawaii (September 1972), 8, 132, 152, 153; for seventh round of talks scheduled in 1973, 132; Hana, Maui, Hawaii (1971), 8, 127, 128, 147; Palau (April 1972), 8, 130; Saipan (1970), 8, 126; Saipan (January 1971), 127; Washington, D.C. (1969), 8, 124; Washington; D.C. (July 1972), 8, 130

Nixon, Richard M., 21, 127, 137, 145

Outer islands, problems of contact with the, 112,113

Palau, 3, 50, 112; District Legislature, 7; establishment of trade schools in, 26; fishing operations on, 165; language, 111; influx of Japanese into, 14; Japanese headquarters in Koror, 25; majority favors free association, 122; Micronesian Occupation Center in, 70; negotiations in Koror in 1972, 130, $145,147-149,153$; new political events in, 171, 172, 174; opposes use of their lands for military purposes, 133; political parties in, 71; Protestant school for girls on, 24

"Planning-for" approach, 63, 64

"Planning-by" approach, 63, 64

Political awareness, 21, 25, 91; development of three groups of differing, 33

Political parties, 71, 72

Political unity, inception of, 70,71

Ponape District: Catholic church in, 24; Community College in, 70; Congress, 7 ; influx of Japanese into the, 14; majority favor free association, 122; Spanish headquarters in, 25; special session of Congress 
of Micronesia in 1972 in Kolonia, 152,153

Population growth, problems of, 73

Posttrusteeship government, 73; logic of centralization in the, 75

Poverty, 73, 149, 156, 159

Presidential system, 73, 75-77, 138

Pro-Japanese element, 56, 106

Public schools, establishment of, 11 , 24

Regionalisms, problems of, 119, 120, 139

Religious revolution, 24

Responsibility, 21, 22; development of, 62

Saipan: American provisional capital now at, 25; Congress of Micronesia meets in 1971 in, 127; Catholic church school on, 24; negotiations in 1970 in, 126; political parties in, 71

Salii, Lazarus E., 58, 59, 163; as cochairman of negotiation team, 127

Secularization, 34, 35, 136; its impact on the weakening of family ties, 34

Security, 100

Self-determination, $45,46,61,86,98$, 157; as a doctrine of revolutionary change, 50 ; as defined by the United Nations, 48; no guarantee for minority groups under, 50; present problems of, 50,52

Self-government, $21,28,43,64,94$, $98,140,146-148,175$; in Micronesia within the next few years, 123

Self-respect, $21,28,43,98,150$

Separatism, an issue of reality, 172, 173,175

Silk, Representative Ekpap, 127, 132

Social awareness, lack of, 21

Social change, 31

Spain, 3, 16, 62, 135; Christianization and pacification by, 12; domination by, 10; period of rule of, 136

Status quo, 64, 80, 82

Strategic interests of the United States, 55, 84, 108; in the Pacific, 138

Tradirion: as opposed to modernization, 92, 93; destruction of, 113; forces of, 92
Traditional system, 20, 30, 31

Transportation system, 70; need for adequate, 100

Travel, early restrictions on, 57

Treaty of Tordesillas, 9-11, 135

Truk, 112, 120; church-affiliated educational institutions on, 24; District Congress, 7 ; educational institutions on, 24; Independence Coalition, 72 ; majority favors free association, 122; meeting of Congress of Micronesia in, 127; option for complete independence by, 122 , 123,140

Trusteeship Agreement, 4, 14, 84, $135,150,164$; agreement of certain moral and legal rights under the, 105 ; principles of self-determination included in the, 61

Trust Territory, 55, 57, 60, 105, 109, 157; as one political unit, 173,174 ; economic survey of, 106; military takeover by United States Navy of, 5 ; problems of fragmentation in the, 53; administration reflects the general attitude of Washington, D.C., 107; role of revolutionary innovators in the, 65 ; under the Department of the Interior, 5

Unification, problems of, 110, 113$115,143,172$

Unilateral termination, $46,82,147$, 151 ; as a key issue in United StatesMicronesia negotiations, 128, 129

United Nations, 48, 49, 53, 54; Committee on Decolonization, 51; defines the right of self-assertion, 45 ; Resolution 1514 of the, 53; special responsibilities of the, 51 ; standards and conditions as indicators of a people's readiness for self-government, 101

United States, 20,48; acquisition of land for military without just compensation, 56; and its free association with Puerto Rico, 77; as a model for future Micronesian way of life, 68; assumes trusteeship of Micronesia at end of World War II, 20; concept of freedom involving responsibility for Micronesians, 20; confusion about its future plans for Micronesia, 63; control of $\mathrm{Mi}$ - 
cronesia's defense and foreign affairs by the, 150; creation of judicial and legislative branches in Micronesia by, 85,86 ; dilemma concerning future plans for $\mathrm{Mi}$ cronesia, 164, 165; establishment of schools and training installations by the, 26; finally showing more interest in Micronesian problems, 87; lack of creation of executive branch of government in Micronesia, 85, 86; military interest in Micronesia, 105; period of control of Micronesia by the, 136; policies to contain the Micronesian people, 106; responsibility to view the Trust Territory as one political unit, 174; revision of attitudes toward Micronesia, 119

Urbanization, process of, 30, 32-36, 136
Warnke, Paul C., 130, 179

Westminster system, 76, 77

Williams, Franklin Haydn, 130, 145; appointment of, 127, 137; position on Micronesian unity of, 171 ; takes a new stand on free association, 128

World War II, 20; destruction during, 104; Japanese treatment of Micronesians during, 20

Yap, 7; Congress, 7; majority favors free association, 122; Spanish headquarters in, 25

Young generation, 82, 83; as antiEstablishment, 156; as apostles of change, 88

"Zoo" theory, 56, 146 
As he comments, there are those in Micronesia who prefer Coca-Cola to coconuts, and others who prefer coconuts to Coca-Cola. Whatever the final resolution, both of these preferences must be respected and accommodated.

The problems facing Micronesia are immense and pressing. Here in straightforward language is the view of the dilemma by one man-a man completely immersed in the struggle to realize the rights of 100,000 people to a better life.

CARL HEINE, a Marshallese by birth, attended high school and college in the United States, receiving a B.A. degree from Pacific University in Oregon. After college, Mr. Heine joined the Trust Territory government, and, since 1969 , has been deputy district administrator for Yap District, Western Caroline Islands. From 1971 to 1973 , he was staff director for the Joint Committee on Future Status, Congress of Micronesia. For the 1973-1974 school year, he has been awarded a graduate fellowship from the East-West Center's Technology and Development Institute, and will work toward a master's degree in political science at the University of Hawaii. Mr. Heine is the author of several articles on the Micronesian political situation published in the Micronesian Reporter, Journal of Pacific History, and Pacific Islands Monthly. 